\title{
PHYSICAL AND ELECTRICAL
}

\section{INSTRUMENTS}

MANUFACTURED, BY

\section{THE CAMBRIDGE}

SCIENTIFIC INSTRUMENT COMPANY, LTD.,

CAMBRIDGE, ENGLAND.

AND

92, HATTON GARDEN, LONDON, E.C.

CAMBRIDGE :

PRINTED AT THE UNIVERSITY PRESS.

1903 





\section{PHYSICAL AND ELECTRICAL}

\section{INSTRUMENTS}

MANUFACTURED BY

THE CAMBRIDGE

SCIENTIFIC INSTRUMENT COMPANY, LTD., CAMBRIDGE, ENGLAND.

AND

92, HATTON GARDEN, LONDON, E.C.

GOLD MEDAL, International Inventions Exhibition, London, 1885.

DIPLOMA OF HONOUR, International Exhibition of Medicine and Hygiene, Rome, 1894.

GRAND PRIX, Exposition Universelle, Paris, 1900.

CAMBRIDGE :

PRINTED AT THE UNIVERSITY PRESS.

1903

All Rights reserved. 
We also publish the following Catalogues which will be sent post free on application:-

Physiological Apparatus.

Callendar Electric Recorders, Platinum Thermometers and apparatus for the measurement of Small Resistances.

"The Measurement of Temperature by Electrical Means."

Microtomes and Accessories, English Edition.

$\begin{array}{lll}\prime & \cdots & \text { French }, \\ , & \text { German },\end{array}$

Duddell Patent Oscillographs. 


\section{NOTE.}

This Catalogue forms one of a reprint of 350 copies.

A few of the prices have been revised and the section describing the Duddell Oscillographs has been omitted. A separate Catalogue describing these instruments has recently been published.

A new Edition of the "Physical and Electrical. Instruments" Catalogue is in preparation.

October, 1903. 
$$
1707
$$ 


\section{PREFACE}

7 THIS Catalogue describes some of our Instruments which we believe to be of special interest to Physicists and Electricians, it also includes many instruments suitable for Higher Grade Schools and Technical Colleges.

'The instruments distinguished by a capital " $\mathrm{E}$ " were originally designed by Prof. Ewing for use in the Engineering Laboratories in Cambridge. They are examined by him before they leave the workshop.

We are prepared to make instruments described in recent scientific papers or in advanced 'Text-books, in many cases instruments required for original investigations have been supplied by us; either these were made from the designs of the experimenter or the Company designed the instrument to suit the case. A separate workshop is fitted with the most modern tools to deal with this class of work.

In order to facilitate the transaction of business with our clients, we have given a telegraphic code word to every article in the Catalogue, and have also added a list of code words for dates and numerals.

THE CAMBRIDGE SCIENTIFIC INSTRUMENT CO., LTD.

February, 1902. 


\section{DIRECTIONS FOR FILLING ORDERS.}

Terms:-Cash with Order or good English reference.

Foreign Orders must be accompanied by either a remittance, or instructions for payment in London, on delivery of Bills of Lading, \&c.

Cheques and Post Office Orders to be drawn payable to "Scientific Instrument Co. Ltd." and crossed London and County Bank, Cambridge.

The greatest care is exercised in packing, but we cannot hold ourselves responsible for breakages in transit. In the event of any damage occurring, application should be made at once to the Railway Company or carrier.

One-half the invoice price is allowed for returned packing cases, when actually received, carriage paid, if returned within fourteen days from delivery.

This list cancels all previous ones, and is subject to alteration without notice.

Trunk Line Telephone. "Cambridge, No. 6."

A B C Code used.

Telegraphic Address. "Instrument, Cambridge."

The Cambridge Scientifie Instrument Company, Ltd.

Carlyle Road,

Cambridge,

England. 


\section{SECIIONS.}

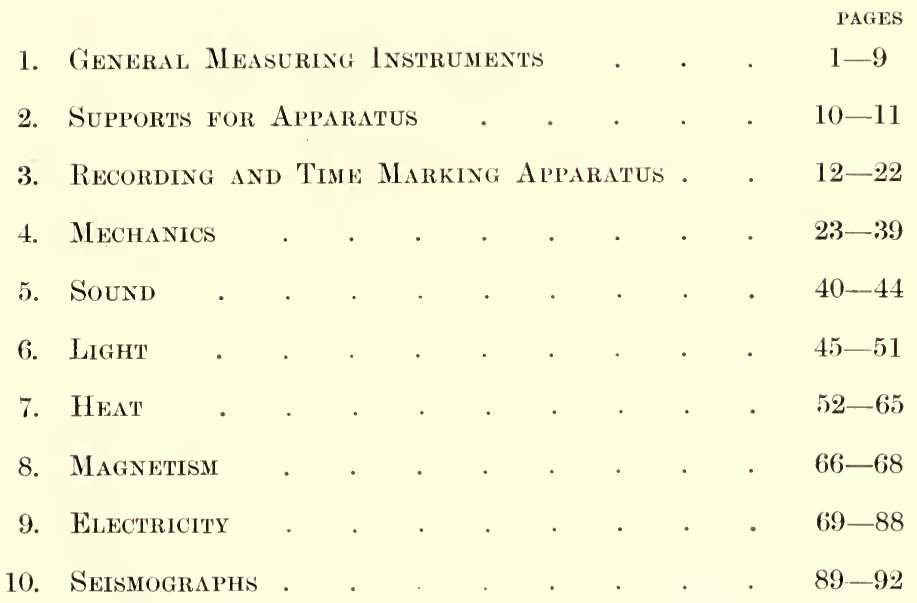


Telegraphic Address "INSTRUMENT, CAMBRIDGE."

\section{TELEGRAPHIC CODE.}

For general purposes the A B C Code Book, Eden Fisher \& Co., 1883, is used, from which we have by permission extracted the Code-table of Numerals. The other code words have been specially selected for this list.

What is the price of

Gaban.

What is the price, time of delivery and best terms for

Gabardine.

Quote price f. o. b. London of

How soon could you deliver?

Gabionage.

Gaelic.

Have you in Stock?

Must be delivered by

Could deliver the order in

We could deliver in one month from receipt of order

Gainage.

Gainsayers.

Gainstand.

Gainstrive.

We could deliver in two months from receipt of order Galangal.

We could deliver in months from receipt of order

Galeuted.

We have the instruments in Stock

Galeopois.

We have none of the order in Stock

Gallant.

We have part of the order in Stock, delivery of whole amount, on

Galleas.

Order received

Order has not been received

Gallinule.

Gallnut.

Add to our order of

Gracecup.

Please deliver at once the following apparatus, we are writing by this mail

Galoche.

We have not heard from you in reply to our letter of Gamagrass.

Wait our next letter before doing anything further Gambrel.

Waiting your further instructions regarding Gambroon.

What you suggest will do quite well Gamekeeper.

We camnot understand what you mean, send full particulars Gammoning.

We are sending full particulars by this mail Gangliform.

Extra expense will be Gangtooth.

Letter received Gangweek.

Reply by cable Gardenplot.

Kindly refer us to your bankers or agents for payment Gardenware.

How were goods sent?

When did goods leave?

Garfish.

Gargoyle. 
We will ship by

Goods have been duly received

Ship by Grande Vitesse

Ship by Petite Vitesse

Ship care of

If goods have not left, await our next letter

Goods have arrived damaged, please inform carriers

Insure for amount of Invoice

Shall we insure goods to your order?

Please send a copy of your latest catalogue
Garnier.

Garrotting.

Gaseous.

Gaslight.

Gasmain.

Gasoscope.

Gasretort.

Gastric.

Gateman.

Gatherable.

\section{TABLE OF DATES.}

To obtain the code-word for any particular date, add the word for the month to the word for the date, thus the 16th March=nameless.

\begin{tabular}{lc|lc} 
Date & Code-word & Date & Code-word \\
First & Mad & Seventeenth & Near \\
Second & Main & Eighteenth & Neat \\
Third & Make & Nineteenth & New \\
Fourth & Mail & Twentieth & Night \\
Fifth & Man & Twenty-first & Noon \\
Sixth & Map & Twenty-second & Odd \\
Seventh & Mar & Twenty-third & Oil \\
Eighth & Mat & Twenty-fourth & One \\
Ninth & Meet & Twenty-fifth & Otter \\
Tenth & Mid & Twenty-sixth & Out \\
Eleventh & Milk & Twenty-seventh & Pack \\
Twelfth & Mine & Twenty-eighth & Page \\
Thirteenth & Moss & Twenty-ninth & Pick \\
Fourteenth & Mount & Thirtieth & Pin \\
Fifteenth & Mull & Thirty-first & Pill \\
Sixteenth & Name & & \\
& & & \\
Month & Code-word & Month & Code-word \\
January & Dust & July & Root \\
February & Head & August & Star \\
March & Less & September & Stone \\
April & Ling & October & Town \\
May & Peg & November & Wards \\
June & Rice & December & Well
\end{tabular}




\section{TABLE OF NUMERALS.}

$\begin{array}{rll}1 \text { Rompermos } & 27 \text { Rumoreitos } \\ 2 \text { Rompieapo } & 28 \text { Rupestral } \\ 3 \text { Rompitura } & 29 \text { Rupieabra } \\ 4 \text { Ronearia } & 30 \text { Rusearius } \\ 5 \text { Roncavate } & 31 \text { Sabbatum } \\ 6 \text { Ronehasen } & 32 \text { Sabbiavate } \\ 7 \text { Ronciglia } & 33 \text { Sabedoria } \\ 8 \text { Rondaccio } & 34 \text { Sabeliano } \\ 9 \text { Rondinette } & 35 \text { Saberetes } \\ 10 \text { Romflante } & 36 \text { Sablecitos } \\ 11 \text { Rongigata } & 37 \text { Sabogales } \\ 12 \text { Rorasteis } & 38 \text { Saborguen } \\ 13 \text { Roriferous } & 39 \text { Sabrosico } \\ 14 \text { Rosolavate } & 40 \text { Saeadinero } \\ 15 \text { Roupagem } & 41 \text { Saeafondo } \\ 16 \text { Roventate } & 42 \text { Sacamolero } \\ 17 \text { Rovinatore } & 43 \text { Saeamuelas } \\ 18 \text { Rubagione } & 44 \text { Sacapotras } \\ 19 \text { Rubefacio } & 45 \text { Saeatapon } \\ 20 \text { Rubellate } & 46 \text { Sacrarium } \\ 21 \text { Rubiginous } & 47 \text { Saerosanct } \\ 22 \text { Ruedecitas } & 48 \text { Safarias } \\ 23 \text { Ruemperas } & 49 \text { Safradeira } \\ 24 \text { Rufescent } & 50 \text { Sagapeno } \\ 25 \text { Rugumasti } & 51 \text { Sagiseano } \\ 26 \text { Ruisenores } & 52 \text { Sagrativo }\end{array}$

$\begin{array}{ll}53 \text { Sagrestia } & 79 \text { Saltaleme } \\ 54 \text { Sahornaste } & 80 \text { Saltativo } \\ 55 \text { Sahumaba } & 81 \text { Salteriaba } \\ 56 \text { Sahumerio } & 82 \text { Salticaba } \\ 57 \text { Sainetillo } & 83 \text { Salticaron } \\ 58 \text { Salacismo } & 84 \text { Saludasen } \\ 59 \text { Salamalec } & 85 \text { Salutirend } \\ 60 \text { Salassero } & 86 \text { Salvajitos } \\ 61 \text { Salbader } & 87 \text { Salvaroba } \\ 62 \text { Saleochada } & 88 \text { Salvatiehe } \\ 63 \text { Soldatori } & 89 \text { Salvigia } \\ 64 \text { Saleratus } & 90 \text { Sambladura } \\ 65 \text { Salieastro } & 91 \text { Samenader } \\ 66 \text { Saliditas } & 92 \text { Sampognino } \\ 67 \text { Saliscendo } & 93 \text { Sanaresso } \\ 68 \text { Salmantino } & 94 \text { Sanchinas } \\ 69 \text { Salmeggia } & 95 \text { Sanfonina } \\ 70 \text { Salmuerado } & 96 \text { Sangioveto } \\ 71 \text { Saloneillo } & 97 \text { Sangonedo } \\ 72 \text { Salpavate } & 98 \text { Sangrentes } \\ 73 \text { Salperemo } & 99 \text { Sanguifero } \\ 74 \text { Salpetrig } & 100 \text { Sanieato } \\ 75 \text { Salpieamos } & 150 \text { Seaponito } \\ 76 \text { Salpieola } & 200 \text { Scogliera } \\ 77 \text { Salpinga } & 250 \text { Sembievole } \\ 78 \text { Salsedine } & 300 \text { Silabeaba }\end{array}$




\section{GENERAL MEASURING INSTRUMENTS.}

1. Short Reading Microscope. An instrument designed for Lord Rayleigh for measuring small differences in length. A pair of microscopes with cross wires and fitted with Zeiss objectives are fixed in a vertical position to a pair of frames, which can slide along a gun-metal bed. Each frame is provided with a micrometer screw with a divided head reading to $01 \mathrm{~mm}$. to give it a slow horizontal motion of $30 \mathrm{~mm}$.

Single (See Fig. 1) ... £10. 0s. 0d. Forhail. Per pair ... £18. 10s. 0d. Forinsocal.

If fitted with Zeiss eye-pieces 25s. extra for each microscope.

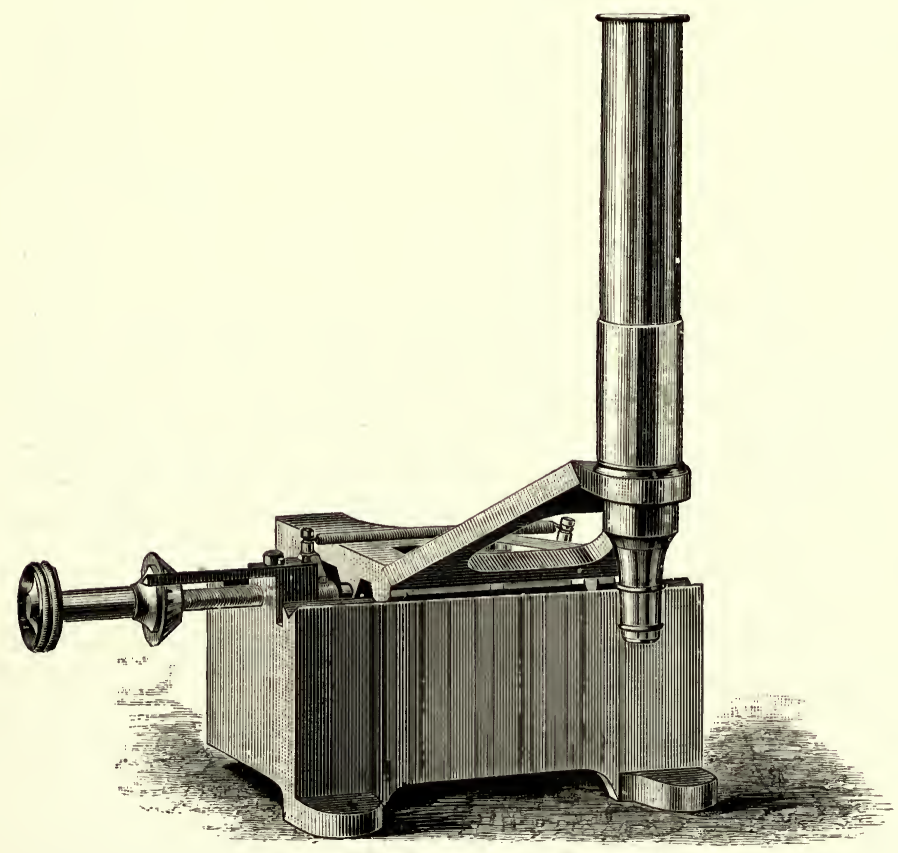

Fig. 1. No. 1.

2. Long Reading Microscope. The bed in this instrument is $350 \mathrm{~mm}$. long, and the two frames supporting the two microscopes can be moved freely by hand along its whole length. By turning two clamping screws, the micrometers are brought into action in the required positions and the reading taken. The shape of the frames allows the microscopes to come very near to each other. 
The two microscopes are the same type as those shown in Fig. $1 \quad £ 20$. 0s. 0d. Forkchuck.

If microscopes are fitted with Zeiss eye-pieces, 50s. extra.

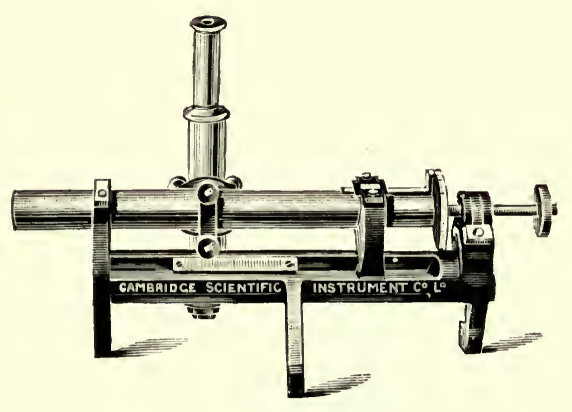

Fig. 2. No. 3.

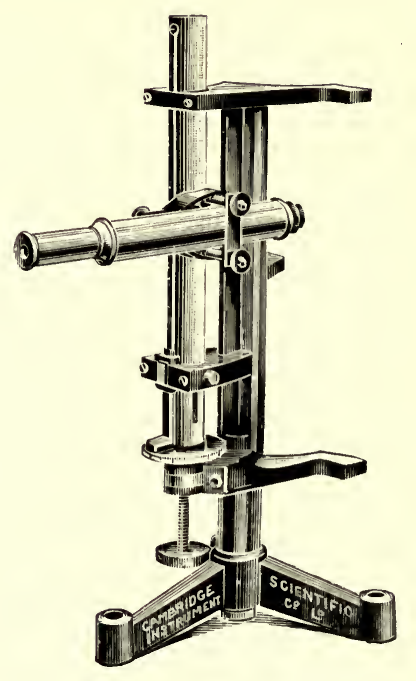

Eig. 3. No. 4 .

3. Comparator and Cathetometer combined. This consists of a micrometer microscope mounted on a steel tube and capable of being used in either a vertical or horizontal position. The instrument is provided with a micrometer head and will read to $01 \mathrm{~mm}$. A stand is supplied so that the whole instrument will stand vertically and can be used as a cathetometer.

For use in horizontal position only (Fig. 2) $\quad . . \quad \ldots . \quad \ldots \quad £ 12$. 10s. 0d. Forkhead.

4. Ditto with stand for use in vertical position (Fig. 3) ... £14. 10s. 0d. Forlaying.

5 E. Screw Travelling Microscope for measurements of length, with Zeiss objective and eye-piece. Reading to $002 \mathrm{~mm}$. $\ldots 12$. 0s. 0d. Destroy.

\section{Micrometers for measuring Celestial Photographs designed} and constructed to order.

The errors of the instrument recently made for the Cambridge Observatory are inappreciable. (See "The Cambridge Machine for Measuring Celestial Photographs" by A. R. Hinks, Monthly Notices, Roy. Astron. Soc. Vol. Lxi. p. 444.)

6. Cathetometer. In this instrument the telescope is supported by a carriage sliding on a vertical steel rod $75 \mathrm{~cm}$. long and fixed to a cast iron tripod foot, with levelling screws. The carriage only touches the steel rod at the points of four adjustable screws. The object glass of the telescope is $25 \mathrm{~mm}$. in diameter and can be focussed on an object from 1 metre distance to infinity. The telescope 


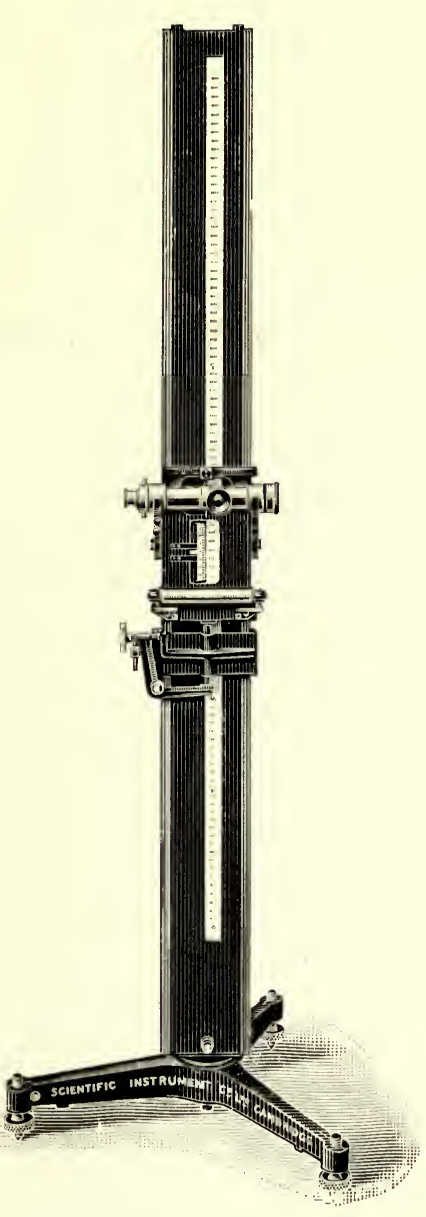

Fig. 4. No. 7 .

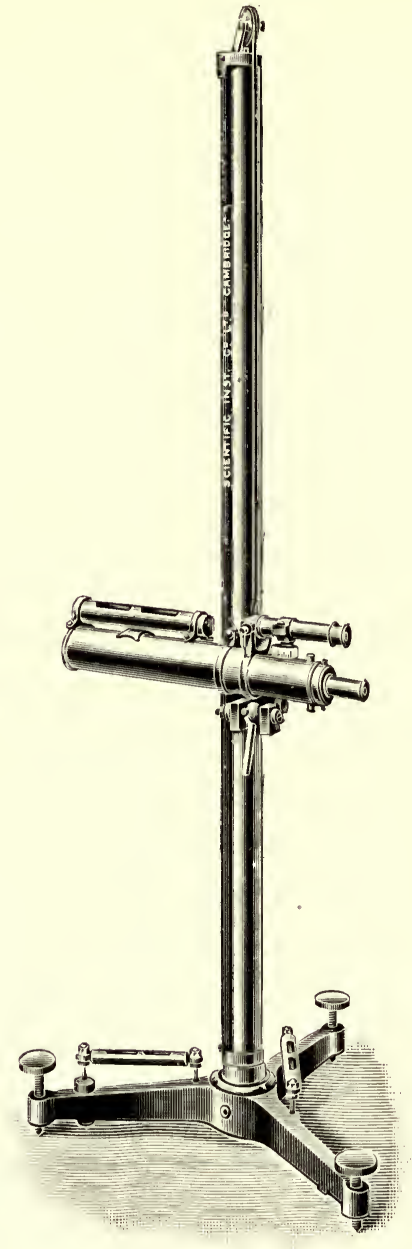

Fig. 5. No. 9.

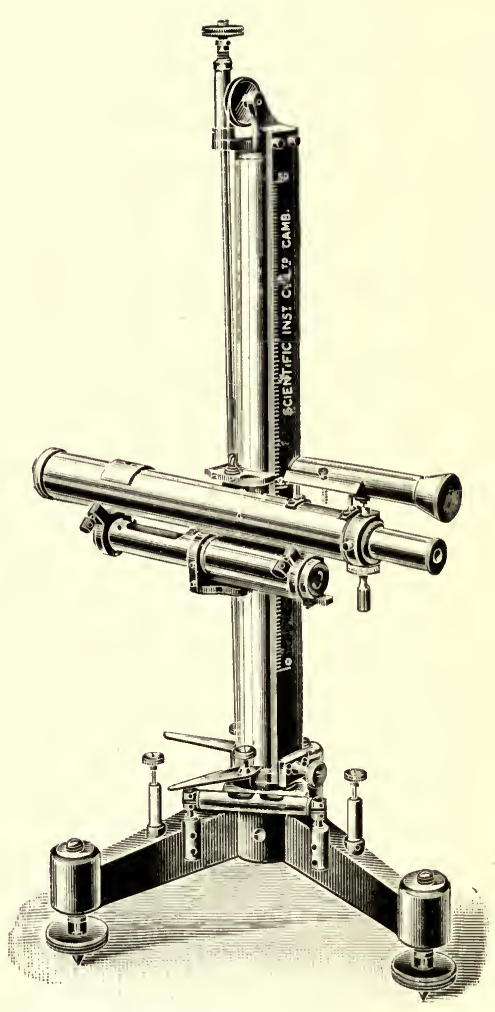

is furnished with a level and a fine adjustment for vertical motion. No scale is provided. The general design of this instrument is shown in Fig. 7

£12. 10s. 0d. Formalism.

7. Cathetometer, with heavy column turning on its axis. The column is 1.15 metres high, the scale is divided into mms., and furnished with a vernier reading to $\frac{1}{20} \mathrm{~mm}$. The telescope is fitted with rack and pinion for focussing and spirit level. The object glass is $27 \mathrm{~mm}$. aperture. Readings may be obtained at

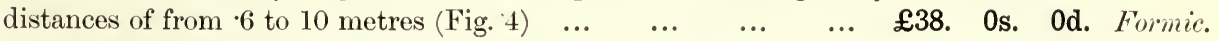

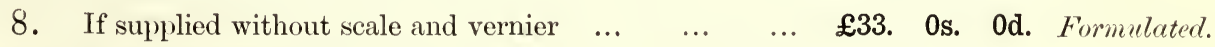

9. Cathetometer. The vertical support of this instrument is a weldless steel tube, standing upon a tripod foot furnished with spirit levels and 
levelling screws. The telescope has an object, glass of $35 \mathrm{~mm}$. diameter, is provided with rack and pinion adjustment for focussing, and a sensitive spirit level. By turning a screw with a milled head the telescope itself may be placed absolutely level just before a reading is taken, without touching the levelling part of the whole instrument. The telescope is supported by a cord passing over a pulley and attached to a counter weight hanging inside the steel tube. This permits the telescope to remain in any position without clamping; a simple form of slow motion is also added.

With scale 1 metre long divided to mms. and provided with microscope and arrangement for reading to huidredths of a millimetre (Fig. 5) $£ 50$. 0s. 0d. Gimmalbit.

10. Table Cathetometer. This instrument resembles Cathetometer No. 9 in general design with the exception that the scale is $50 \mathrm{~cm}$. long (Fig. 6)

$£ 40$. 0s. 0d. Girdlebel.

Standard Scales, for use with Cathetometers. See pages 6,7 .

11 E. Reading Telescope, with horizontal traversing motion, to serve instead of a Cathetometer for reading the extension of springs, deflection of beams,

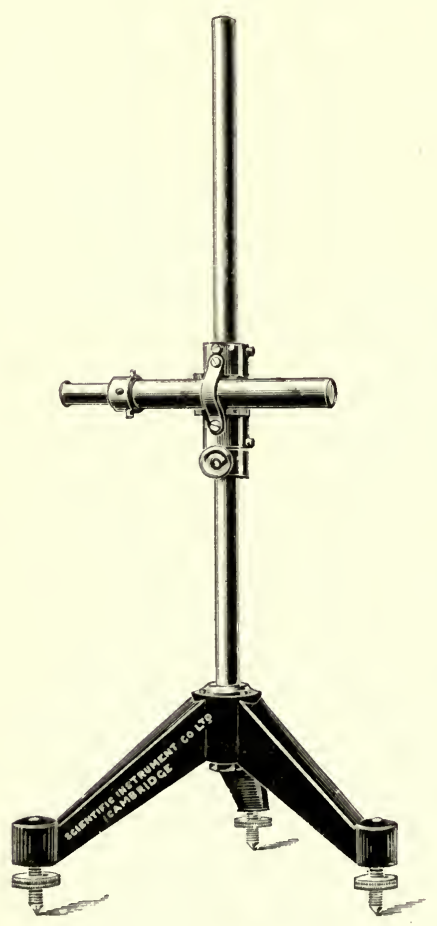

Fig. 7. No. 13. etc., with attached scale for reading by reflection. The scale may be placed horizontally or vertically as desired. The supporting rod is $560 \mathrm{~mm}$. long. The telescope is provided with cross wires and saddle piece adjustment for focussing. This will be found an exceedingly useful instrument in a laboratory $\quad \ldots \quad \ldots \quad \ldots \quad \ldots 6 . \quad 0$ s. 0 d. Dingles.

\section{Quincke's Microscope Ca-} thetometer, as used at the Cavendish Laboratory. The difference of levels is read by a micrometer eye-piece placed in a horizontal microscope of small magnifying power. A Ramsden eye-piece is used; the glass plate at the common focus has a scale of $5 \mathrm{mms}$. divided into 50 parts, and figured for convenience of reading. Two V's cut in a brass frame carry the microscope; the frame itself can slide about on a small glass table, placed horizontal by means of a spirit level $\quad \ldots \quad £ 10$. 0s. 0d. Carriboo.

\section{Micrometer Telescope, as used} by Mr E. H. Griffiths for reading thermometers. The telescope is supported by a carriage sliding on a vertical steel rod fixed to a cast iron tripod foot.

The telescope has an object glass of very 
short focal length and may be described as a very weak microscope. A finely ruled glass scale is fixed at the focus of the eye-piece and the draw tube is adjusted so that 10 of its divisions correspond to one millimetre in the object examined

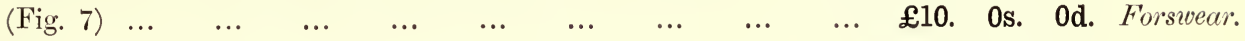

Spherometer, This instrument consists of a small brass table with three

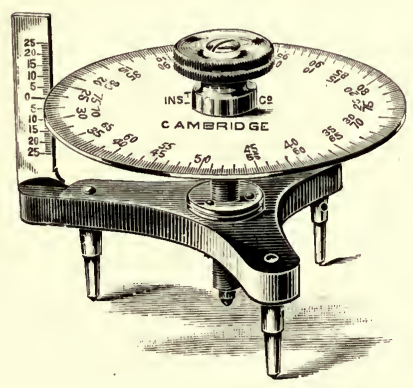
steel legs, the pointed feet of which form an equilateral triangle. A micrometer screw works through the centre of the table and thus forms another leg. The head of this screw is divided so that it advances $0.01 \mathrm{~mm}$. for a turn of one division. The distance of the point of the screw above or below the plane passing through the pointed feet of the three other legs can be read off' at once.

Fig. 8. No. 14 .

14. Large size, legs 3 cms. apart, in case complete (Fig. 8)

£4. 4s. Od. Forsworn.

15. Small size, legs $1.5 \mathrm{cms}$. apart, in case complete

£3. Os. Od. Forthgoing.

\section{Micrometer Gauges. (Brown and Sharpe's make.)}

16. $\frac{1}{2}$ inch steel gauge, reading to $\cdot 001 \mathrm{inch}$, in case

£1. 4s. 0d. Foremost.

17. Ditto with ratchet to prevent undue pressure on faces of gauge; in case

18. $13 \mathrm{~mm}$. steel gauge reading to $01 \mathrm{~mm}$. in case

£1. 4s. 0d. Fortunise.

19. Ditto with ratchet, in case

£1. 7s. 6d. Gingebre.

20. 1 inch steel gauge reading to $\cdot 001$ inch; in case

£1. 7s. 6d. Forsando.

21. Ditto with ratchet, in case.

£1. 11s. 0d. Fossilized.

22. $25 \mathrm{~mm}$. steel gauge reading to $01 \mathrm{~mm}$. in case

£1. 7s. 6d. Canoneer.

23. Ditto with ratchet, in case

£1. 11s. 0d. Foully. 
24. Cup Micrometer. A simple piece of apparatus for accurately

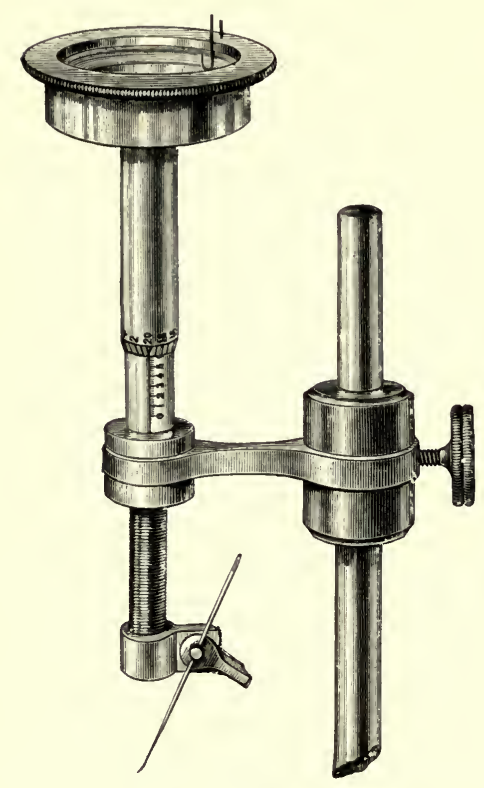

Fig. 9. No. 24. measuring small vertical movements. It will measure to one-hundredth of a mm., and is useful in many cases where a cathetometer is commonly used. The vertical movement of the screw is read in the usual manner from a scale giving the number of complete turns, and a divided head giving the parts of a turn. A cup is fixed to the upper end of this screw and is partially filled with oil. An ordinary sewing needle is then attached to the object to be measured. It should be vertical, with the point downward, and directly over the oil cup. The micrometer screw is turned and the reading taken when the needle point touches the surface of the oil. The image of any object reflected in the surface of the oil is distorted at the moment of contact, shewing distinctly when the reading should be taken. It is sometimes more convenient to place the oil cup on the object to be measured and to fix the needle to the lower end of the micrometer screw as shewn in Fig. 9.

Stand extra (see p. 10)

3s. $9 d$.

£4. 4s. 0d. Befall.

25. Spirit Level Tester. An instrument for measuring the value of the graduations on a spirit level bulb. The bulb is placed in V supports forming part of a stand resting on three feet; one of these is a micrometer screw with a divided head. When this screw is turned the bulb is tilted through a known angle, and the value of the divisions on the surface of the glass can be found. One division on the divided head corresponds to an angle of one second

£6. 0s. 0d. Foxish.

26. Amsler's Planimeter. Made of German Silver, metric units, in case

27. Ditto with both metric and English units ... $\quad \ldots \quad £ 3 . \quad 10$ s.
28. Opisometer. Divided. Made of German Silver with bone handle

£2. 12s. 6d. Foxy.

15s. 0d. Fragmental.

Standard Scales. Of hard brass, $10 \mathrm{~mm}$. thick, and $20 \mathrm{~mm}$. wide, divided into centimetres, the first decimetre into millimetres; in case.

29. $50 \mathrm{~cm}$. long

£2. 10s. 0d. Frank. 


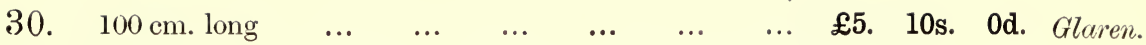

A ring fitting can be supplied with these scales in order that they may hang vertically when used in conjunction with Cathetometers Extra 7s. 6d.

Standard Metres of Nickel Steel. These are made of an alloy of steel containing 36 per cent. of nickel, recently introduced into Metrology as the result of experiments made at the Sevres International Bureau of Weights and Measures by Dr Guillaume. The principal advantage of this alloy is its very slight dilatability, between one-fifth and one-tenth of that of platinum, it takes a fine polish, and is non-oxydisable in dry or moist air.

31. Metre Scale of Nickel Steel $10 \mathrm{~mm}$. thick and $20 \mathrm{~mm}$. wide divided into cms., and the first decimetre into mm. $\ldots . \ldots £ 11.10 \mathrm{~s}$. 0d. Frantic.

32. Standard Metre Scale of Nickel Steel $\mathrm{H}$ form, divided in the neutral zone. The divisions are millimetres, the first and last mm. being

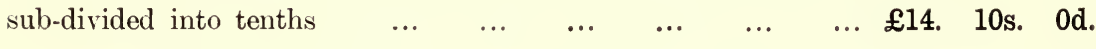

33. Vertical stand for supporting the above scales $\ldots \quad £ 5$. 0s. 0d. Fraudful.

34. Bar Callipers for measuring up to $250 \mathrm{~mm}$. in length, divided to

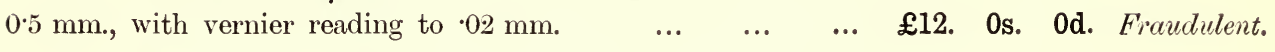

35. Millimetre Paper Scales. These are printed on stout paper from a carefully divided copper plate, and are $500 \mathrm{~mm}$. long. each

6d. Freebooter.

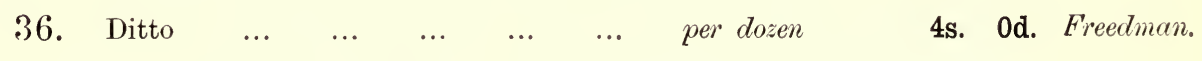

37. Pocket Callipers, designed by Sir Joseph Hooker. These have two scales, one reading to twentieths of an inch and one to $\mathrm{mm}$. In case

10s. 6d. Freeze.

38. Straight Line Dividing Machine, for laboratory use. The screw has a thread of one $\mathrm{mm}$. pitch and divisions as fine as $005 \mathrm{~mm}$. can be made. The graving tool is stationary and arranged so that lines of different lengths are made mechanically. The object to be divided moves automatically as the screw is turned. A scale $350 \mathrm{~mm}$. long can be graduated without interruption.

£27. 10s. 0d. Frenzical.

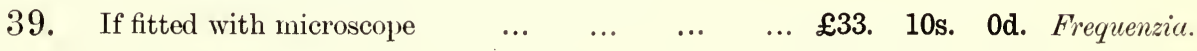

40. Dividing Machine. The same design as that described above but with two micrometer microscopes sliding over the whole length of the machine,

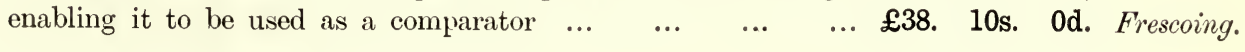


41. Dividing Machine for making straight scales of any length less than $35 \mathrm{cms}$. The screw is $1 \mathrm{~mm}$. pitch and gears into a sliding carriage carrying the engraving point. The gun-metal nut is hinged and split so as to be readily disengaged from the screw in order that the carriage may be quickly moved along the bed. The bed and fittings are of a specially rigid character. The pirotted

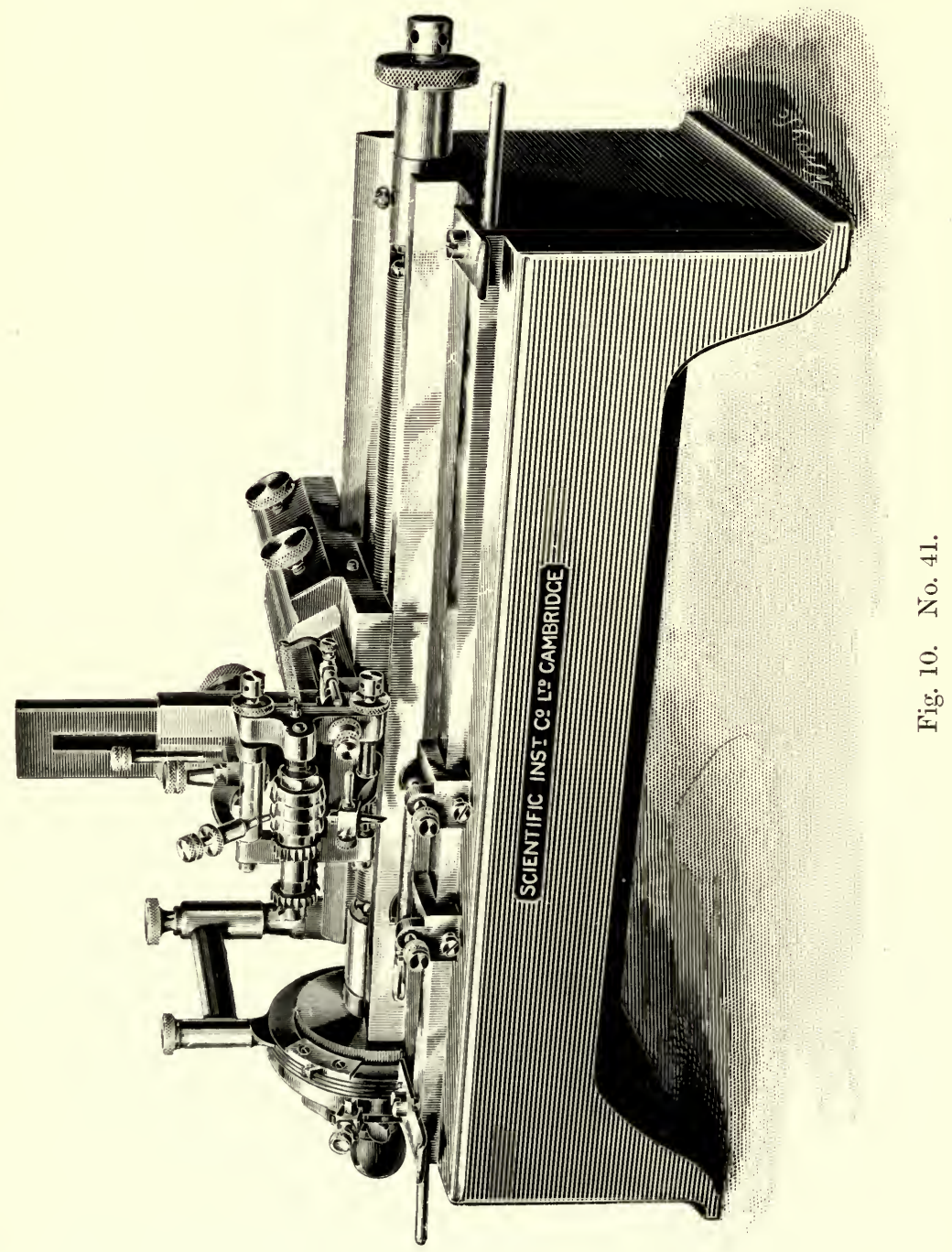

cutting frame is fitted with cams and adjustable stops for making every fifth or tenth division longer than the others. Special clamps for fixing thermometer and 
barometer tubes and flat scales are supplied. A microscope can be attached to the carriage at an extra charge of £3. The Micrometer wheel is divided into 200 divisions. Lengths can thus be measured to $004 \mathrm{~mm}$. (Fig. 10)

£57. 10s. Od. Fresknew.

This machine is strongly recommended for general laboratory work.

42. Do. do. To divide a maximum length of $50 \mathrm{~cm}$. £62. 10s. 0d. Caraboid.

43. Do. do. To divide a maximum length of $100 \mathrm{~cm}$. £74. 10s. 0d. Carapace.

44 E. Step by Step Dividing Machine, useful for making verniers and dividing short scales. In this machine the graving tool is carried at the end of a long arm. The scale to be divided is mounted on a carriage which is made to advance by means of a micrometer screw (Fig. 11) $\ldots . \quad \ldots \quad £ 10$. 0s. 0d. Descrying.

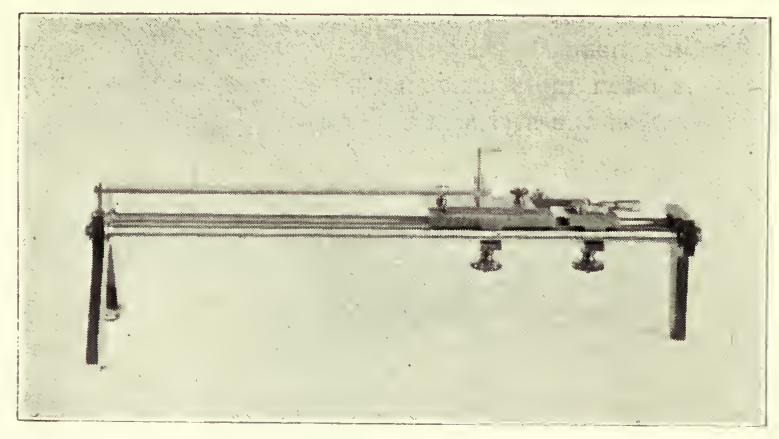

Fig. 11. No. 44. 


\section{SUPPORTS FOR APPARATUS.}

45. Simple Stands. A square cast-iron base standing on three feet, supports a vertical steel rod $30 \mathrm{cms}$. long and $10 \mathrm{~mm}$. in diameter. All our smaller instruments, such as Time Markers, \&c., are made to clamp on a rod of

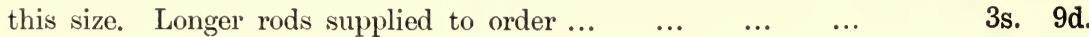

Adition.

46. Do. do. with larger base and rod $50 \mathrm{cms}$. long. An illustration of this

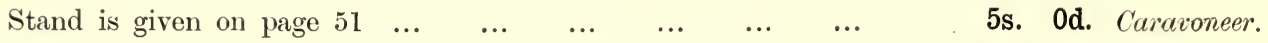

47. Adjustable Simple Stand. This is similar to the Simple Stand, but with a heavier base and longer vertical steel rod. It is used to support a Time Narker or any small instrument which marks on the smoked paper on a Recording Cylinder. The vertical rod is capable of rotation about its own axis and thus the scribing styles of two or more instruments can be simultaneously brought into contact with the smoked paper; if the Recording Cylinder is moving quickly this arrangement is often most convenient. By means of a tangent screw the desired pressure between the styles and the smoked paper can be obtained

£1. 10s. 0d. Adipous.

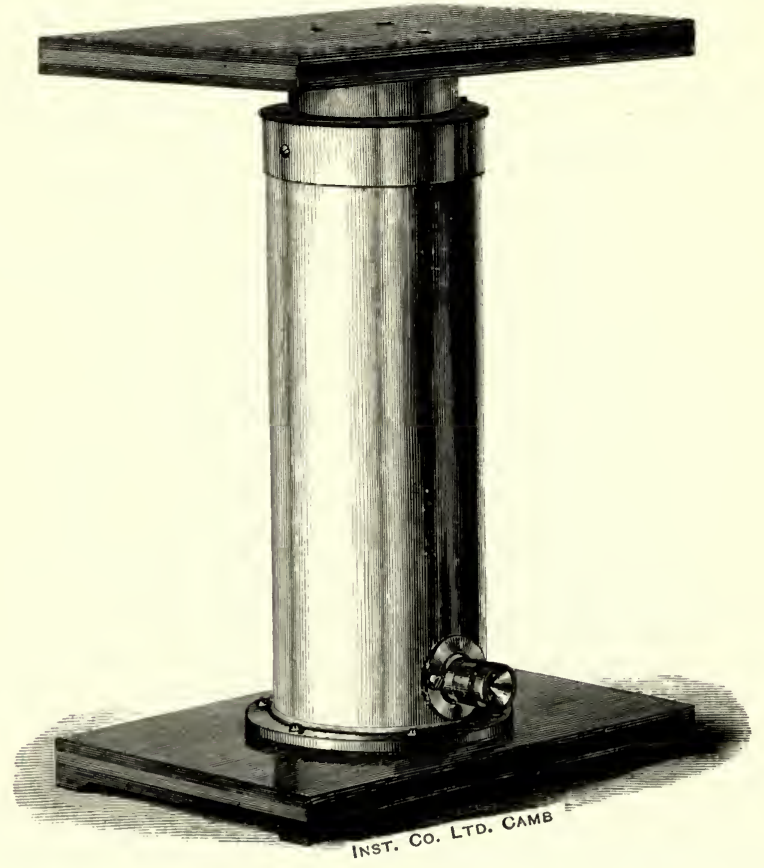

Fig. 12. No. 50. 
48. Cheaper form of above for Students' use as designed by Professor Gotch

49. Adjustable Glass Table, used for Quincke's Microscope Cathetometer or for any purpose requiring a smooth level glass stand capable of vertical adjustment. A piece of plate glass is supported by a rigid vertical steel rod which is clamped to a tripod foot supported by three levelling screws. The height is easily adjustable by slackening a milled head, raising the table by hand and re-clamping when in the required position. The clamp is designed to give a perfectly rigid connection to the tripod foot with a small turn of the screw ; it is

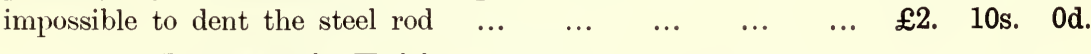

50. Pneumatic Table, for giving a slow vertical motion to any piece of apparatus. A small brass table is fixed to the top of a cylinder sliding inside another brass cylinder. There is air-tight packing between the cylinders ; consequently as the table falls all the air in the cylinder is expelled through a valve. The opening of this valve can be altered, thus regulating the speed with which the table falls. It can be used for supporting apparatus for recording on a revolving cylinder. The valve now supplied is slightly different to that shown in the illustration

£6. 10s. 0d. Admirable.

Geometric Tripod Stands, designed by Professor C. V. Boys, F.R.S. These are made of cast-iron in two sizes and can be so arranged as to form a stand of any desired height. Each tripod makes geometric contact with the one immediately below it.

51. Distance from centre of tripod to centres of feet, $75 \mathrm{~mm}$, height $25 \mathrm{~mm}$. A metal table $155 \mathrm{~mm}$. in diameter is included in a set of one dozen. (See right of Fig. 13) per doz. 12s. 6d. Caninal.

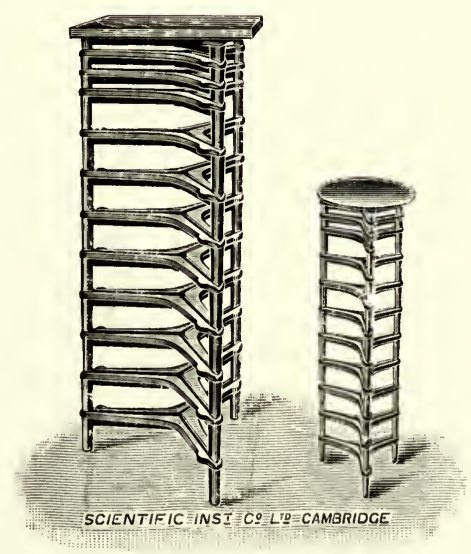

Fig. 13. Nos. 51, 52.

52. Distance from centre of tripod to centres of feet, $175 \mathrm{~mm}$., height $37 \mathrm{~mm}$. (Fig. 13). One tripod in each set of one dozen, has a wooden table $33 \mathrm{~cm}$. square fixed to it, on which apparatus may be placed $\quad \ldots \quad$ per doz. $\quad$ £1. 15 s. 0 d. Canonistic. 


\section{RECORDING AND TIME-MARKING APPARATUS.}

53. Kymograph. Ludwig's model, driven by clockwork. The surface speed of the cylinder can be varied by means of friction wheels from $100 \mathrm{~mm}$.

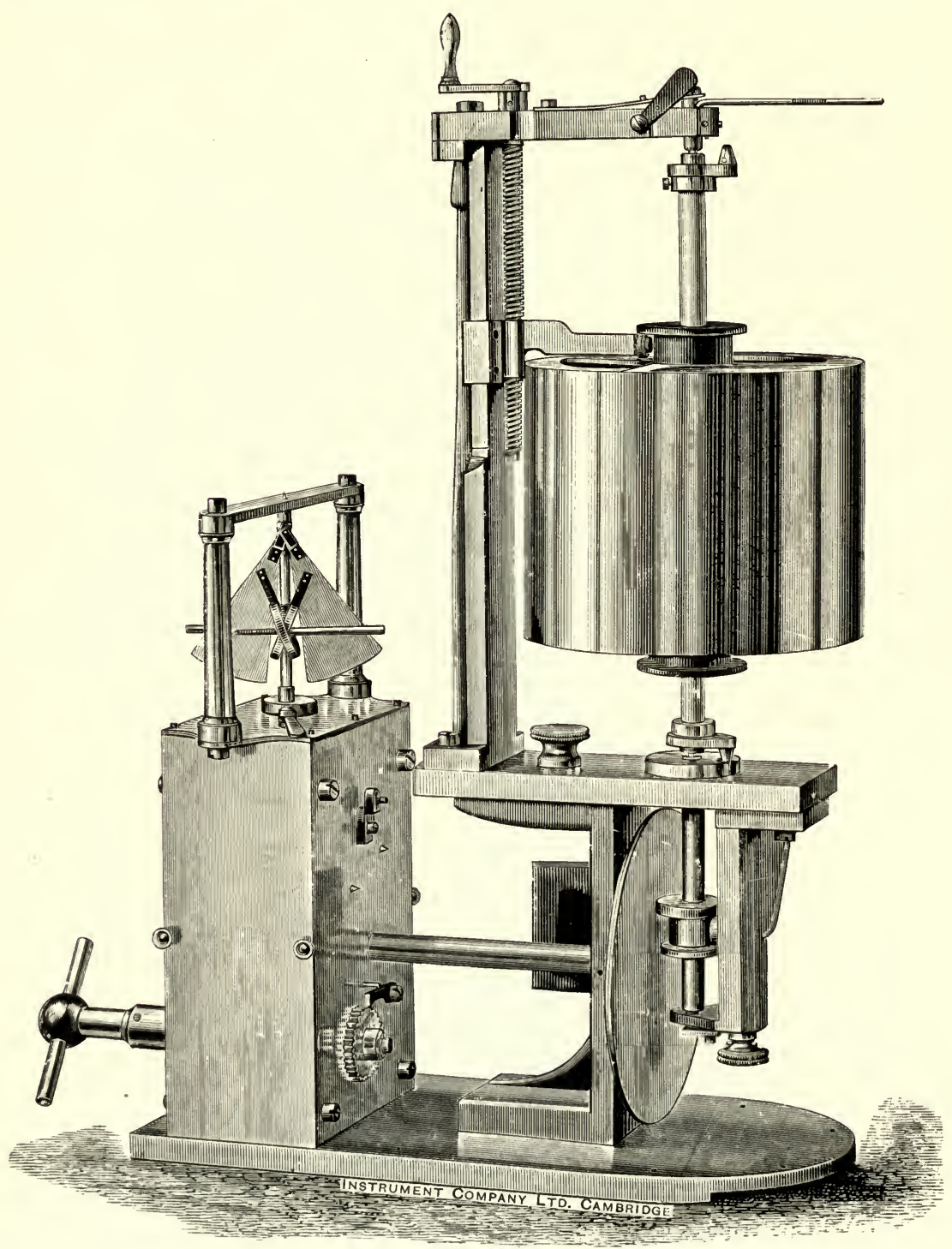

Fig. 14. No. 53. 
per second to $10 \mathrm{~mm}$. in about a minute. The brass cylinder is $130 \mathrm{~mm}$. high and $165 \mathrm{~mm}$. in diameter and can be used with its axis either vertical or horizontal. By turning a handle the cylinder can be moved along its axis through $165 \mathrm{~mm}$. without interfering with its rotation. The clockwork is driven by a spring and the

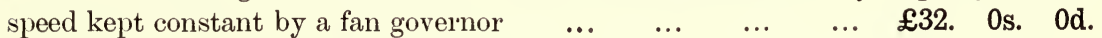

54. Do. with clockwork gearing to automatically move the cylinder laterally along its axis

Instruments similar to Nos. 53 and 54 , but driven by gearing and not by friction wheels, can be supplied at the same prices, but they have not such a variety of speeds as Nos. 53 and 54 .

55. Kymograph for use with a motor or quick running cord. The cylinder is $130 \mathrm{~mm}$. high and $165 \mathrm{~mm}$. in diameter and can easily be removed when it is required to attach and smoke the paper. The mechanism is so arranged as to give ten different velocities. The cylinder will rotate in either direction

£10. 10s. 0d. Abditory.

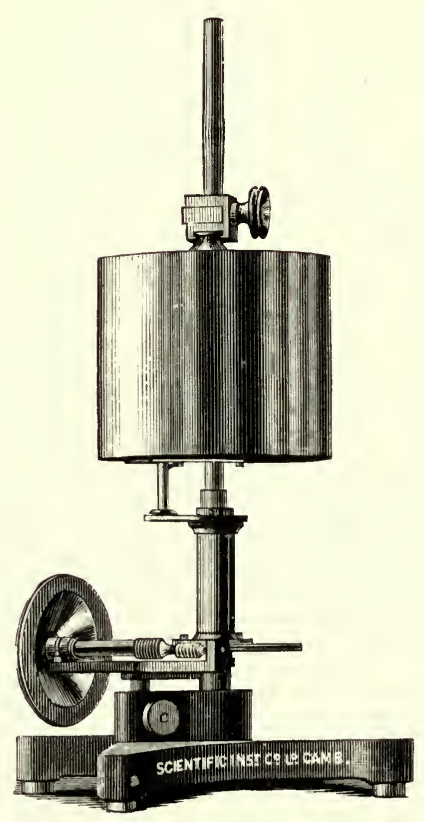

Fig. 15. No. 56.

56. Do. with vertical adjustment. Whilst the cylinder is rotating, it can be made to have a screw motion, thus giving a helical tracing. See Fig. 15.

$£ 13$. 0s. 0d. Abductor. 
Instruments Nos. 55, 56 can be supplied with an arrangement for carrying a long sheet of smoked paper at an additional cost of £3. 10s. 0d. or for continuous paper at an extra cost of £2. 10s. 0d.

57. Kymograph for recording on continuous paper. Similar in design to No. 55 except that it has fewer speeds, and umrolls the continuous paper, which, after passing the position for recording, is rolled up again in a separate roll. This instrument has no vertical movement to the cylinder (Fig. 16) $\ldots . \quad £ 17$. 0s. Od. Abhorrence.

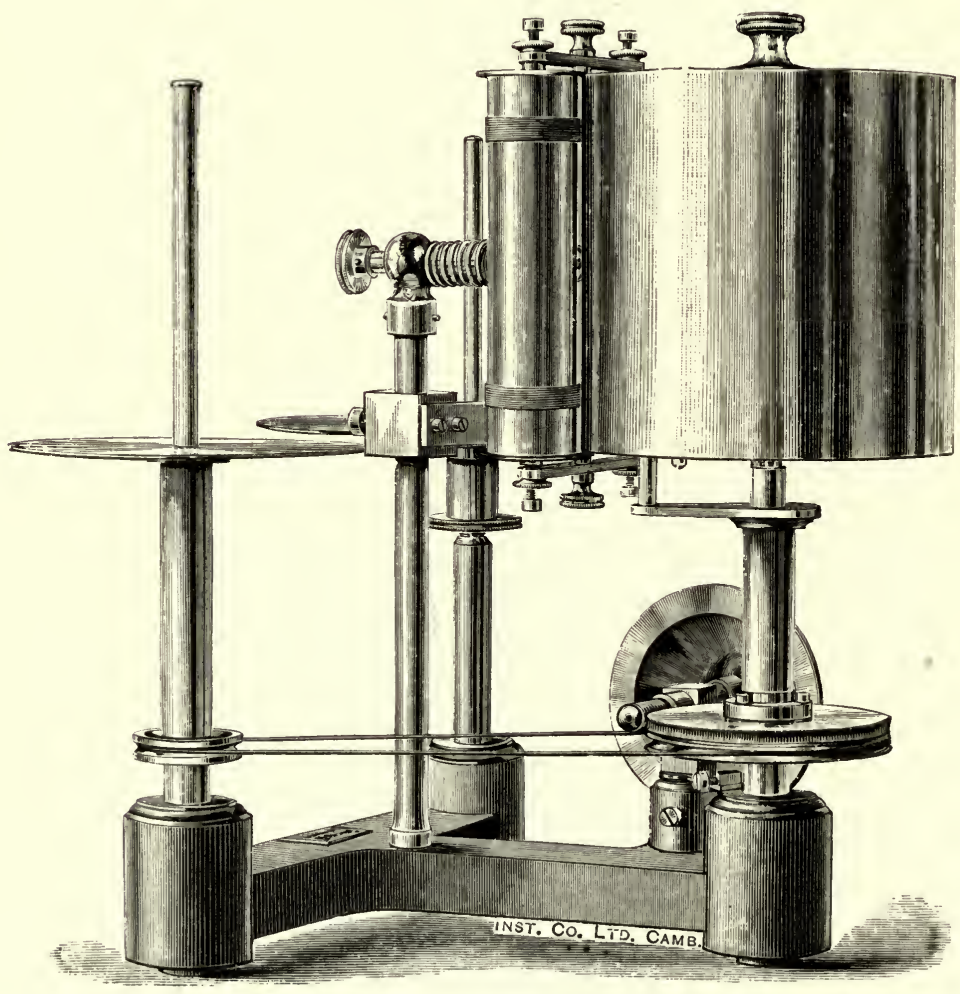

Fig. 16. No. 57.

58. Simple Clockwork Kymograph. A drum which is $130 \mathrm{~mm}$. high and $165 \mathrm{~mm}$. in diameter is made to rotate by means of clockwork placed inside it. By means of a clamping screw the drum may be made to rotate once in

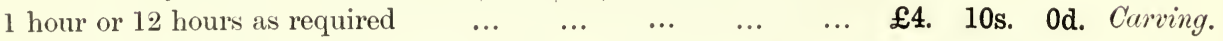

59. Large Drum. A cylinder $152 \mathrm{~mm}$. high and $610 \mathrm{~mm}$. in diameter mounted on a vertical axis. Any form of motor can be used to give the requisite rotation by means of a cord and pulley fixed to the cylinder

$£ 7$. 0s. 0d. Ablocate. 
60. Student's Drum. The cylinder is $130 \mathrm{~mm}$. high and $160 \mathrm{~mm}$. in diameter. It is fitted with a pulley, not shown in the illustration, for driving by a

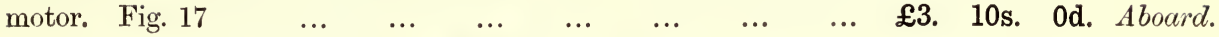

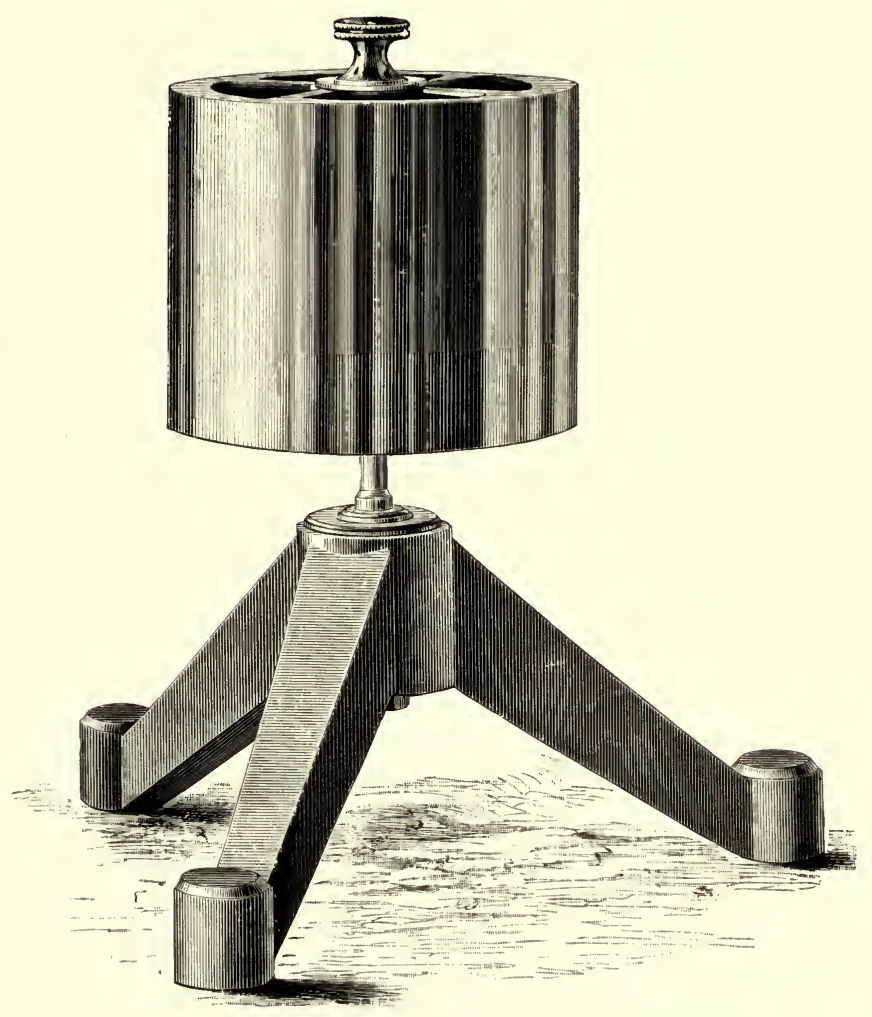

Fig. 17. No. 60.

61. Do. with weight driving arrangement $\quad \ldots \quad \ldots \quad$ \&5. $5 \mathrm{~s} . \quad 0$ d. Abolete.

62. Chronograph for Laboratory Use. A strip of Morse paper $12.5 \mathrm{~mm}$. wide is drawn by means of a motor under three small inking wheels attached to the armatures of three electromagnets. One of these can be connected to a clock making contact every second; the other two magnets are used for recording the physical quantities under observation. A simple arrangement is provided for starting or stopping the movement of the paper whilst the motor is running. A spare reel of paper is carried behind the one in use, and when the supply of paper on the first reel is nearly exhausted the end of the second reel is gummed to it without interrupting the record. This Chronograph was originally designed for Mr E. H. Griffiths, F.R.S., and is one that we warmly recommend for $\begin{array}{lllllllllll}\text { laboratory work. } & \text { Fig. } 18 & \ldots & \ldots & \ldots & \ldots & \ldots & \ldots & £ 25 . & 0 \text { s. } & 0 d .\end{array}$ 


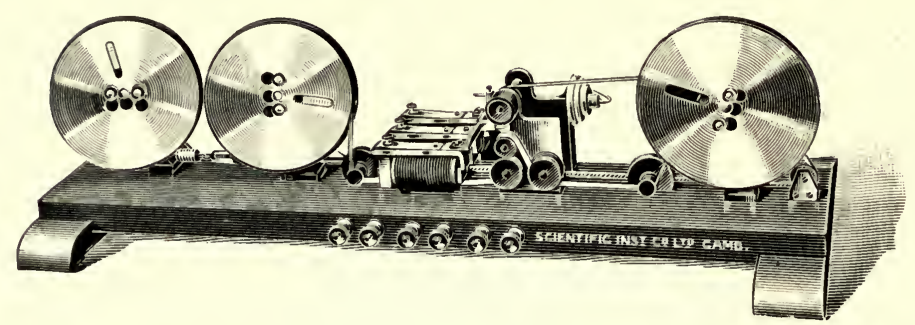

Fig. 18. No. 62.

63. Spare reels of Morse paper, $\quad \ldots \quad \ldots \quad \ldots$ each

1s. Od. Carpetbag.

64. Tube of special printing ink for use with above Chronograph $\ldots$...

2s. 6d. Carve.

65. Chronograph, Hough's Printing. As designed by Prof. G. W. Hough, of the Dearborn University, Evanston, Chicago.

The time of any given occurrence is automatically printed by means of type wheels. An observation may be made and printed to within $\frac{1}{100}$ th of a second. To order.

\section{ACCESSORIES FOR USE WITH KYMOGRAPHS OR RECORDING CYLINDERS.}

66. Specially Constructed Handle for holding the cylinder when smoking the paper

67. Stand for holding cylinder when not in use $\ldots \quad \ldots$

10s. Od. Aboriginal.

68. Shellac varnish for fixing the tracings, per kilo

5s. 0d. Aborsement.

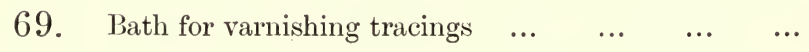

3s. 6d. Abortively.

70. Hürthle's Smoke-spray for smoking the sheets

12s. 0d. Abreast.

10s. 6d. Abricock.

Glazed paper accurately cut to size and one end gummed ready for use with our Kymograph cylinder $130 \mathrm{~mm}$. high and $165 \mathrm{~mm}$. in diameter :

71. 100 sheets... $\quad \ldots$

72. $500 \quad, \quad \ldots$

73. 1000 , 5s. 0d. Abroad.

17s. 6d. Absciss.

... $\quad$ 12s. 6d. Abscond.
Stouter and better quality.

6s. Od. Absolver.

£1. 1s. 0d. Abstrude.

£2. 0s. 0d. Abstruisty. 
74. Glazed paper for use with large recording cylinders $610 \mathrm{~mm}$. in diameter and $152 \mathrm{~mm}$. high.

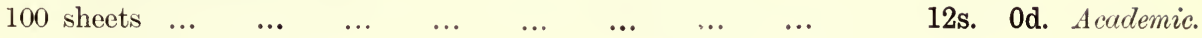

75. Unglazed paper for continuous paper Kymographs $127 \mathrm{~mm}$. wide, in rolls about 250 metres long, $\quad \ldots \quad \ldots \quad \ldots \quad$ per roll $\quad$ 5s. 6d. Accompany.

76. Unglazed paper $127 \mathrm{~mm}$. wide in rolls about 10 metres long, per roll 10d. Accomplish.

77. Do. do. $\quad \ldots \quad \ldots \quad \ldots . \quad$ per 100 rolls $£ 3$. 10s. 0 d. Accompt.

78. Glazed paper $127 \mathrm{~mm}$. wide in rolls about 10 metres long, per roll 1s. 0d. Accordable.

79. Do. do. $\quad \ldots \quad \ldots \quad \ldots \quad$ per 100 rolls $\quad$ £4. 4 s. 0 0d. Accordance.

80. Glass Recording Pen. For many years the want of an improved pen for use with recording instruments has been felt, more especially as a substitute for smoked paper and writing style.

The pen consists of a small vessel containing a fine tube, the capillarity of which is sufficient to maintain a minute drop of ink at the writing point of the tube. There is no difficulty in keeping ink at the point however quickly the pen may be moving. At the same time the pen requires no attention when once started. The fine tube referred to can be removed for cleaning. The clips by which the pen is attached to the style of the instrument are made in two forms, one for use when the pen is attached to the writing arm from the side, as in the "Richard" type of insiruments, and one when fixed from the top or bottom as in many recording gas and water meters. When ordering please state which form of clip is required.

2s. Od. Delving.

81. Bottle of aniline ink for use with Dittmar pens ...

6d. Chafewax.

82. Tuning-Fork Stand, for holding tuning-forks in which the vibrations are electrically maintained. Any of the tuning-forks can be fixed in the slot in the heavy cast-iron block.

The ebonite block supporting the electro-magnet and the mercury cup slides along a rod to suit the lengths of the various forks. The level of the mercury in the cup can be adjusted by means of a screw plunger. The mercury can be kept clean by passing a continuous stream of water over its surface. The amplitude of vibration of the fork can be varied by a lateral adjustment of the electro-magnet; a vertical adjustment also allows the electro-magnet to be fixed at an equal distance from each prong of the fork.

Suitable terminals are fixed to the instrument (Fig. 20) $\quad \ldots$ \&6. 15 s. $0 d . \quad$ Admixtion. 


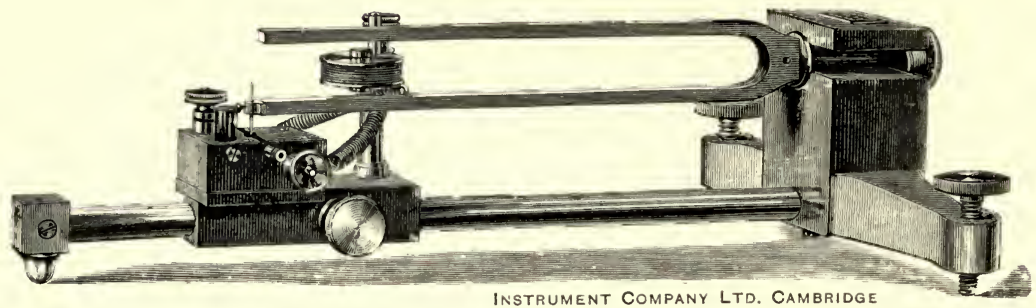

Fig. 20. No. 82 .

83. Tuning-Fork Stand. Cheap form. This is designed to hold the same forks as No. 82, the contact maker and its adjustments being of much simpler construction

Tuning-Forks to fit either of the above stands. These forks are most carefully adjusted and can be relied on for accurate work.

84. Fork making 50 vibrations per second
85.

If the forks are not accurately adjusted but have stamped on them the actual number of vibrations per second.

87. About 50 vibrations per second $\ldots \quad \ldots \quad \ldots \quad \ldots 2.0$ 0s. 0d. Cascarilla.

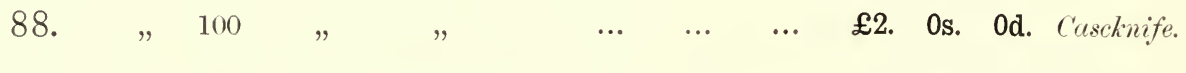

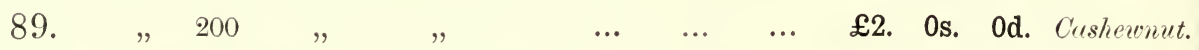

90. Simple Tetanus Spring, or Vibration Contact Maker. A long straight spring is gripped in a brass block which is clamped on to one of our Simple Stands. At each vibration of the spring a platinum wire fixed to its end dips into a mercury cup and completes an electric contact. This cup may be any small vessel standing on the table; and is not supplied with the instrument unless specially ordered. The instrument is used by deflecting the spring with the finger, and then freeing it, when it will vibrate for a short time giving an intermittent current. The speed of vibration can be varied within wide limits by gripping the spring at different

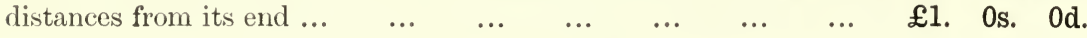

Adientory.

91. Do. do., with graduated scale, so that the spring may be set imme-

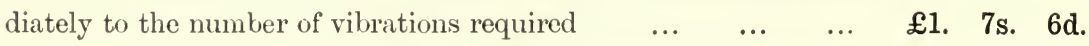

Adversity.

92. Electrically Maintained Tetanus Spring, or Vibrating Contact Maker. This is the same instrument as the above but with the addition of a mercury cup and a small electro-magnet by means of which the vibrations can 


\section{Cambridge, England.}

be maintained indefinitely. The electro-magnet can be adjusted either longitudinally or vertically. The instrument is similar in its action to an Electrically Maintained Tuning-Fork. At the slowest rate it will make about 5 contacts per second

£2. $15 \mathrm{~s}$. 0d. Advice.

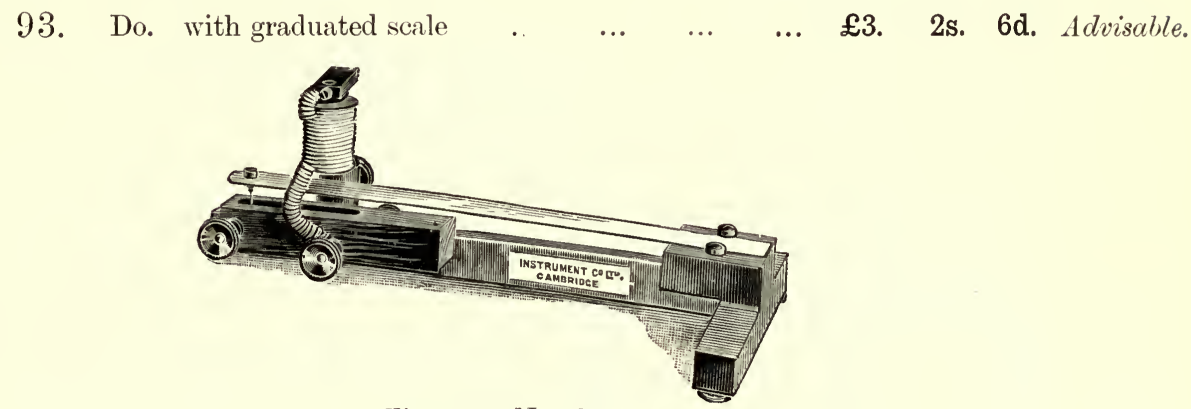

Fig. 21. No. 94 .

94. Contact Breaker to interrupt the current ten times per second; specially designed for students' use. A horizontal steel spring fixed to a cast.iron stand oscillates and completes contact by means of a wire dipping into a mercury cup. The intermittent current thus produced passes through an electro-magnet placed above the spring and keeps it vibrating (Fig. 21)

17s. 6d. Advolition.

95. Clock, for making an electric contact at each second.

It consists of an American Clock Movement modified to beat seconds. A mercury cup is provided, into which a platinum wire dips at every ribration of the balance

£2. 10s. 0d. Advorve.

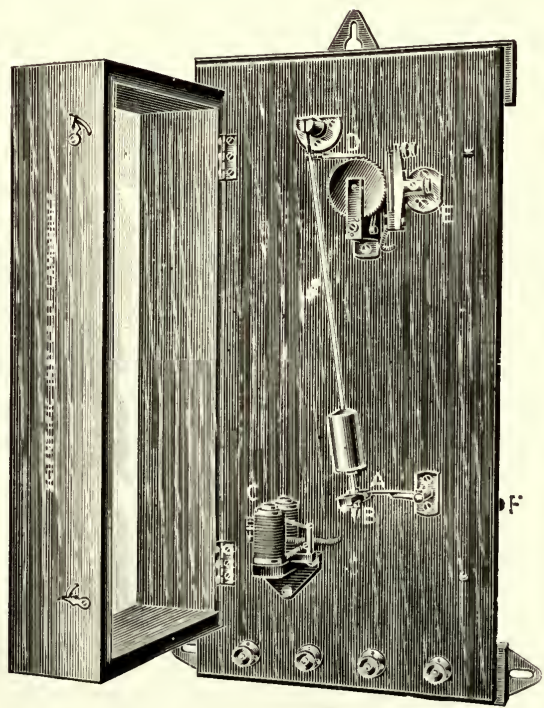

Fig. 22. No. 96. 
96. Brodie's Time Marking Clock. This clock makes an electric contact, every second, or, by a simple movement every two, ten, thirty, or sixty seconds. By an ingenious arrangement an electro-magnet gives an occasional impulse to the pendulum when it deviates from the normal beat. There is also a simple and effective device for starting and stopping the pendulum. An arrangement of ratchet wheels completes another electric contact which is very quick and therefore gives a good tracing with any suitable chronograph.

In polished mahogany case with glass front (Fig. 22) $\quad \ldots \quad £ 7$. Os. Od. Caskiering.

97. Laboratory Seconds Clock. This clock has been designed to fix on the walls of a laboratory where it

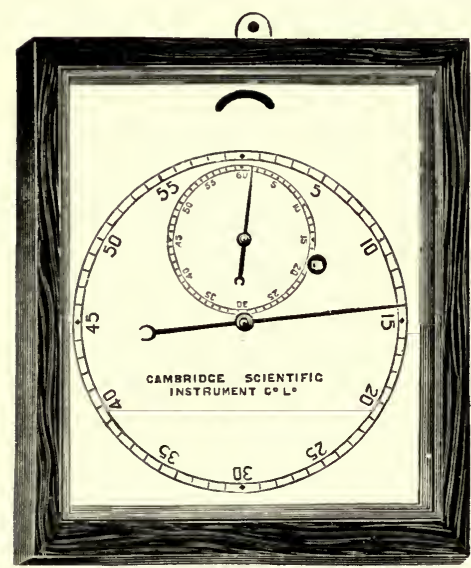

Fig. 23. No. 97 . is often useful to have a clock showing seconds. The large seconds dial is $150 \mathrm{~mm}$. in diameter. The clock can frequently be used instead of a stop-watch. In wooden case. (Fig. 23) ... $\quad \ldots \quad £ 1 . \quad 10$ s. 0 d.

Chainbolt.

\section{Time-Marker, to write} with Ink on Continuous Paper. The armature of a small electro-magnet moves a lever carrying a writing point which is pressed against the moving surface of paper on a recording instrument. When connected to a clock which makes contact at each second, a zigzag line is drawn recording the velocity of the paper. This is useful for analysing any other curve drawn at the same time by another instrument.

The pen is of the syphon form and is very reliable $\quad \ldots \quad \ldots l$...

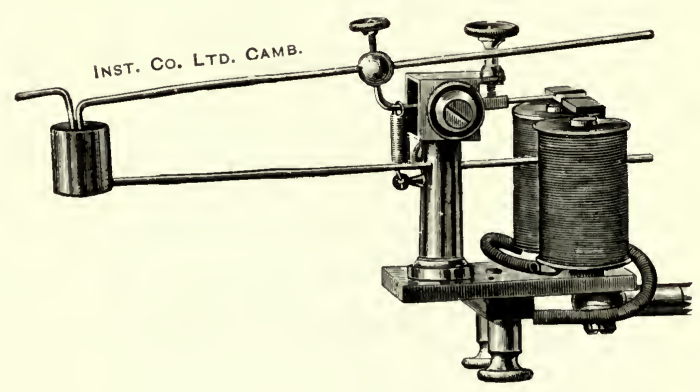

Fig. 24. No. 98 .

99. Do. do. fitted with an Adjustable Support by means of which the pen can be applied to the surface of the paper with great accuracy $\ldots \quad \& 4 . \quad$ 0s. $\quad$ Od. Afflecter.

10(). Time-Marker for Smoked Paper. This form can be used with the currents from an Electrically Maintained Tuning-Fork of slow vibration (Fig. 25) 
101. Do. do. fitted with Adjustable Support ... $\quad \ldots . . \quad$ £3. 0 0s. Od. Afford.

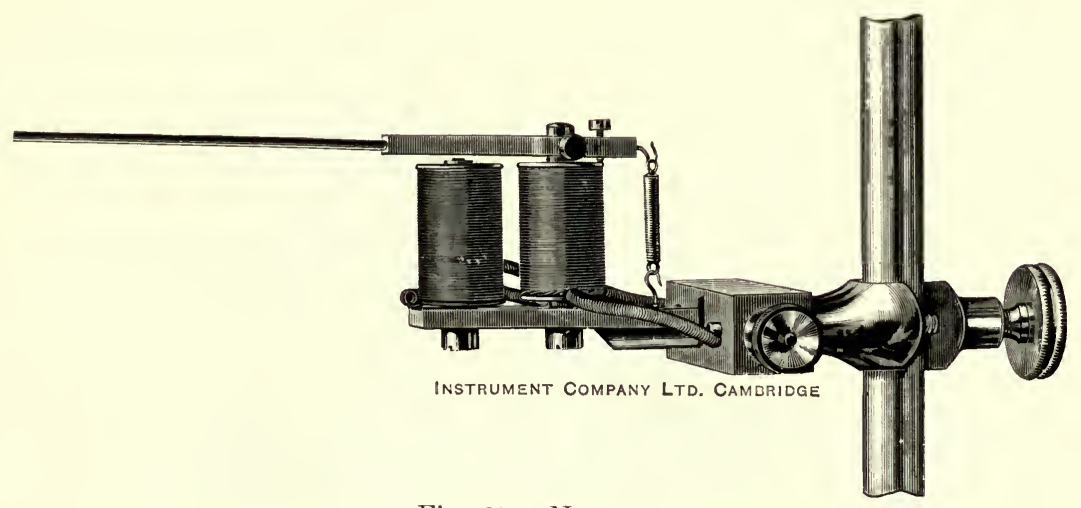

Fig. 25. No. 100.

103. Double Time-Marker for Smoked Paper. A combination of two Time-Markers on one frame, with the styles close together, one directly over the other. The marking points can be brought against the surface of the cylinder at the same moment, their relative positions remain constant, and very little space is taken up on the smoked paper

£3. 10s. Od. Affrap.

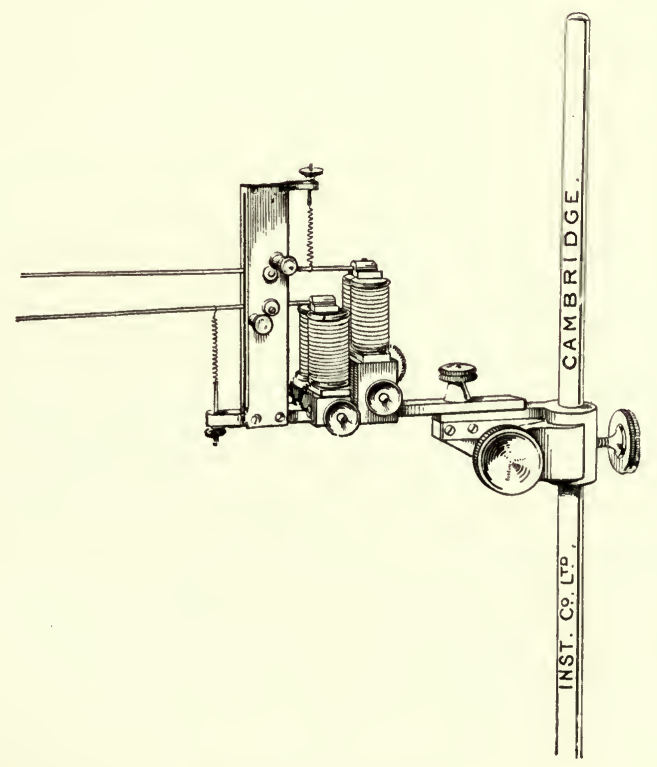

Fig. 26. No. 104.

104. Do. do. fitted with adjustable support (Fig. 26) \&4. 0s. 0d. Afret. 
105. Time-Marker, Deprez Signal. In this form the electromagnets are very small and the moving parts extremely light. It is useful for recording small intervals of time on smoked paper and for use with time-marking

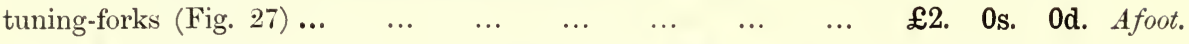

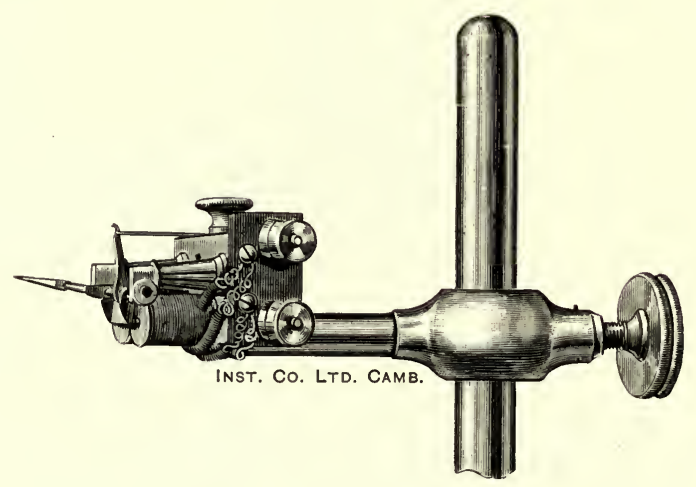

Fig. 27. No. 105.

106. Wo. do. fitted with adjustable support ... $\quad \ldots \quad £ 2 . \quad 10$ s. $0 d$. Iforehand.

109. Double Time-Marker, Deprez Signal. In this instrument two small electro-magnets are mounted close together, their styles writing in two

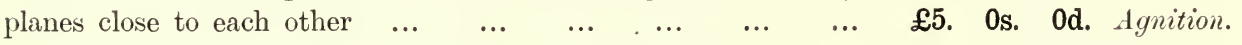

110. Do. do. fitted with adjustable support $\quad \ldots \quad £ 5 . \quad 10$ s. 0 d. Dabster.

For prices of stands for supporting the time-markers see p. 10. 


\section{MECHANICS.}

Instruments with the letter "E" placed after the number are of the form originally designed by Professor Ewing, F.R.S., for use in Mechanical and Engineering Laboratories.

Ewing's Extensometer for measuring the elastic extension and Modulus of Elasticity of specimens of metal under tensile tests. This instru-

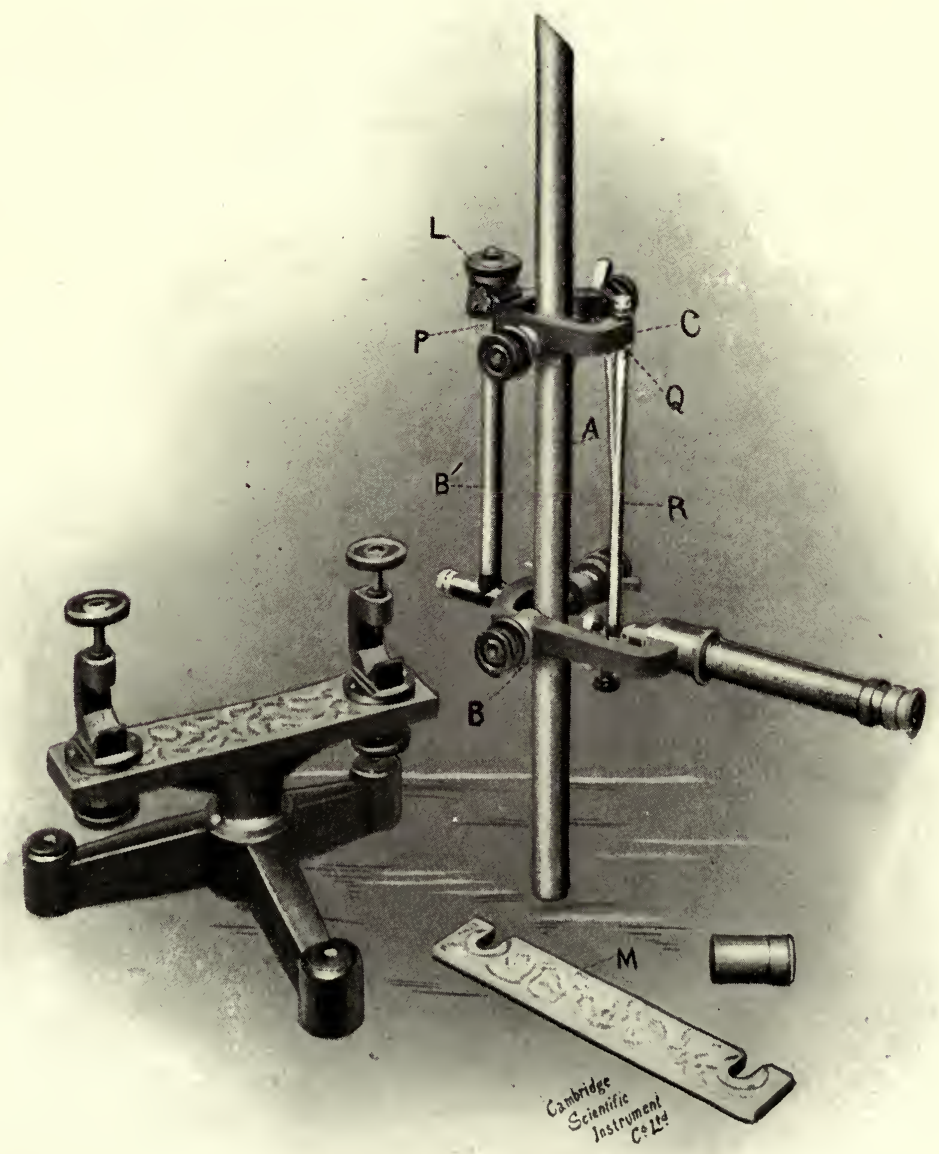

Fig. 28. Nos. 111, 112. 
ment can be quickly applied to any test-piece, and no part of it has to be touched whilst the test is being made.

Two clips $B$ and $C$ (Fig. 28) are attached to the test-piece $A$ by the points of two set-screws. The clip $B$ has a projection $B^{\prime}$ ending in a rounded point $P$ which engages with a conical hole in $C$; when the bar extends this rounded point serves as a fulcrum for the $\operatorname{clip} C$, and hence a point $Q$, equally distant on the other side, moves, relatively to $B$, through a distance equal to twice the extension. This distance is measured by means of a microscope attached to $B$. The microscope forms a prolongation of $B$ and the motion of $Q$ is brought into the field of view by means of a hanging rod $R$. The $\operatorname{rod} R$ is free to slide on a guide in $B$, and carries a mark on which the microscope is sighted. The displacement is read by means of a micrometer scale in the eye-piece of the microscope. The pieces $B$ and $B^{\prime}$ are jointed to one another in such a way that the bar may twist a little, as it is sometimes liable to do during a test, without affecting the engagement of $P$ with $C$. This also obviates any need of absolute parallelism in the axes of attachment of the two clips. But the joint between $B$ and $B^{\prime}$ forms a rigid connection so far as angular movement in the plane of the paper is concerned. This feature is essential to the action of the instrument : it is only then that $P$ serves as a fixed fulcrum in the tilting of $A$ by extension on the part of the specimen.

Fig. 28 is an illustration of the usual form of the complete instrument. The clips $B$ and $C$ are set at 8 inches (200 $\mathrm{mm}$.) apart.

Each division on the microscope scale corresponds to $\frac{1}{5000}$ inch of extension, so that by estimation of tenths of a division readings to $\overline{50000}$ inch may be taken.

The screw $L$ further serves to bring the sighted mark to a convenient point on the micrometer scale, and also to bring the mark back if the strain is so large as to carry it out of the field of view. In dealing with elastic strains there is no need for this, as the range of the scale is itself sufficient to include them, but it is useful when observations are being made on the behaviour of metals as the elastic limit is passed.

To facilitate the application of the Extensometer to any rod a clamping bar $\mathrm{M}$ (shown at the foot of Fig. 28) is added by which the clips $B$ and $C$ are held at the right distance apart with the axes of their set-screws parallel, while they are being secured to the test-piece. Such a clamping bar is especially convenient when the strain has been carried beyond the elastic limit and it is desired immediately to reset the clips to the standard distance apart after the length between them has materially changed by extension of the specimen. The clamping bar must of course be removed before a test begins.

On the left of Fig. 28 an apparatus is also shown for marking off on the specimen the 8-inch length to which the Extensometer is applied when in use. To use this the set-screws are turned back so that the bar rests in its $V$ 's, the upper screws are then tightened upon it; the lower screws are then tightened sufficiently to make their points indent the bar.

\section{E. Extensometer (Ewing's Patent Microscope type).}

This is the standard pattern of the above instrument, applicable to large or small test-pieces, for use on testing machines of either the vertical or the horizontal type, 
in mahogany case complete. The microscope lenses are by Zeiss. See The Strength of Materials, p. 78, Ewing, Univ. Press, Cambridge. (Fig. 28) ... £27. 10s. 0d. Demarcate.

112 E. Apparatus for marking off standard length on testpieces for measurements of elastic extension, for use with Extensometer. See

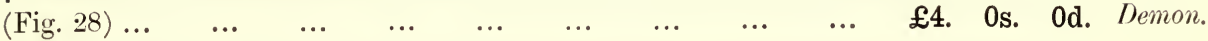

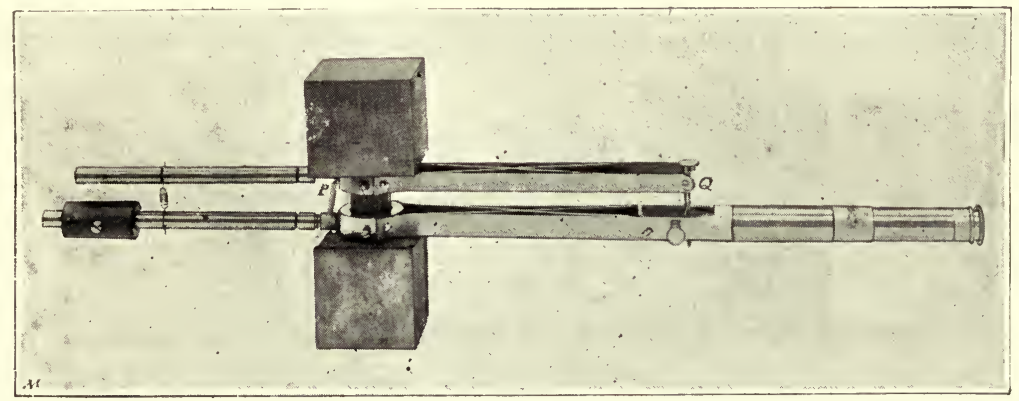

Fig. 29. No. 113.

113 E. Ewing's Extensometer. Special form for measuring the elastic compression of short blocks. See The Strength of Materials, p. 79.

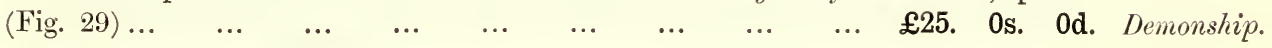

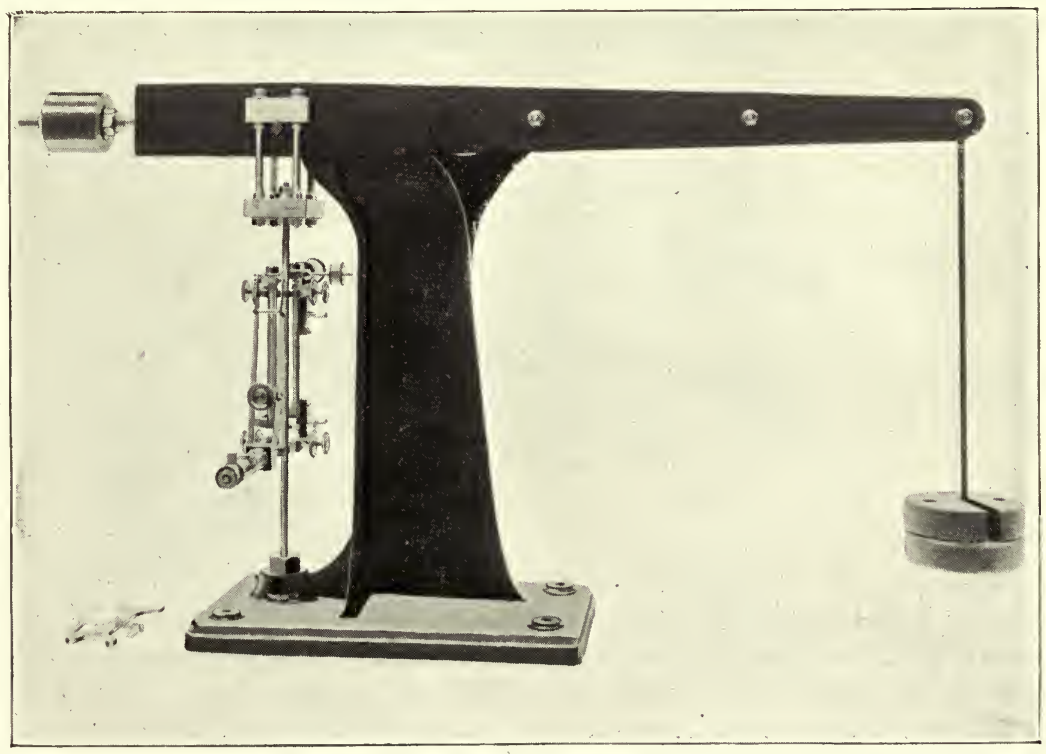

Fig. 30. No. 115 . 
114 E. Ewing's Extensometer for measuring the elasticity of metals in rods of $\frac{3}{8} \mathrm{in} .\left(10 \mathrm{~mm}\right.$.) or $\frac{1}{4} \mathrm{in}$. $(6 \mathrm{~mm}$.) in diameter, for use with the simple testing machine, No. 115

\section{E. Single lever testing machine for use with Extenso-}

meter in measuring modulus of elasticity in rods up to $\frac{3}{8} \mathrm{in}$. $(10 \mathrm{~mm}$.) diameter, with assortment of rods of various metals. Length of rods $50 \mathrm{cms}$. See The $\begin{array}{lllllllll}\text { Strength of Materials, p. 80. (Fig. 30) } & \ldots & \ldots & \ldots & \ldots & £ 20 . & \text { 0s. } & \text { Od. }\end{array}$

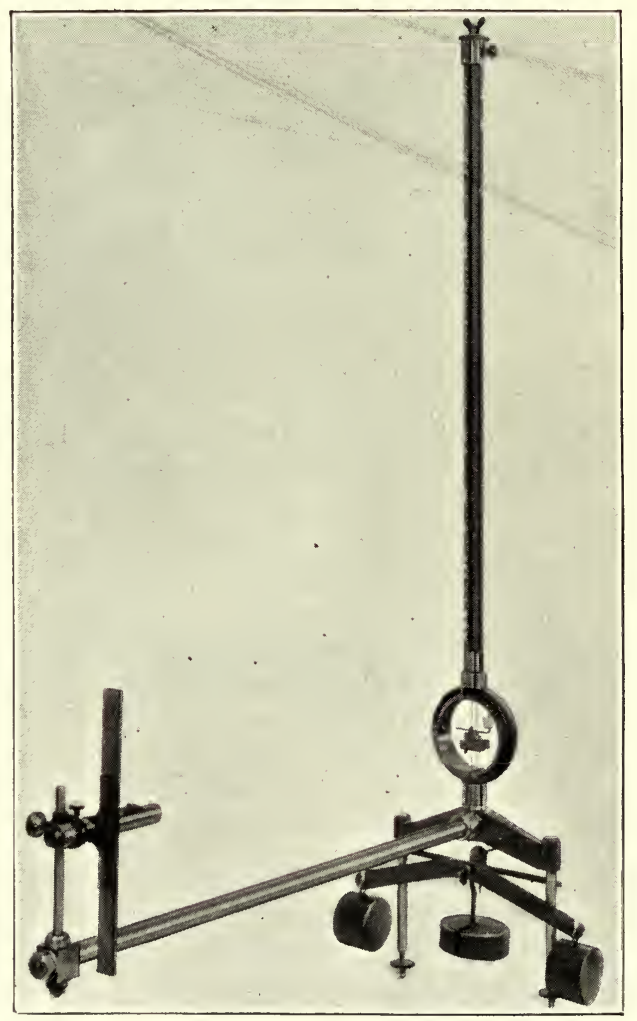

Fig. 31. No. 116.

116 E. Young's Modulus of wires, Tilting Mirror apparatus for accurately measuring, with reading telescope and scale. Length of wires $120 \mathrm{cms}$. By means of this apparatus the modulus of elasticity is accurately measured by the extension of a comparatively short length of wire. See The Strength of Materials, $\begin{array}{lllllllllllll}\text { p. } 82 & \ldots & \ldots & \ldots & \ldots & \ldots & \ldots & \ldots & \ldots & \ldots & £ 10 . & 0 \text { s. } & \text { 0d. Dentilave. }\end{array}$

The instrument has been improved in several details since the illustration, Fig. 31, was made. 
117. Young's Modulus of wires, Searle's Apparatus for determining, and also the deviations from Hooke's Law

The upper ends of two wires are securely fixed to a beam, and from the lower ends hang two brass frames supporting the two ends of a sensitive level. One end of the level is pivoted to one of the frames; the other end of the level rests upon the end of a micrometer screw.

A scale pan is attached to the side of the frame supported by the wire under observation, the position of the level has to be altered by means of the micrometer screw after any alteration has been made in the weights placed in the pan. Extensions in the length of the wire can be read to $001 \mathrm{~mm}$. See Proc. Camb. Phil. Soc., Vol. x. p. 318

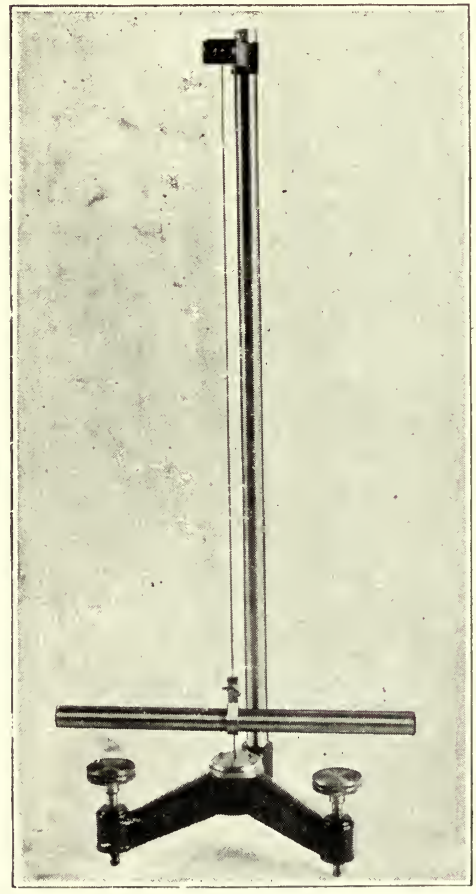

Fig. 32. No. 120.

$£ 5$. 0s. 0d. Catoptric.

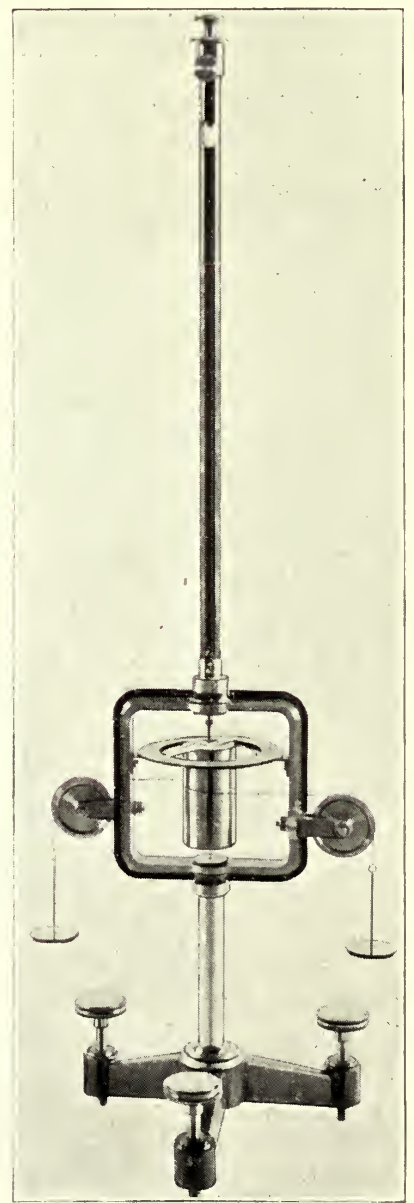

Fig. 33. No. 121. 
118. Young's Modulus of wires, Apparatus for determining. This instrument is similar to that shown in Glazebrook and Shaw's Practical Physics, It consists of : a scale, vernier reading to hundredths of a $\mathrm{mm}$. on the scale, scalepan, weight, and bracket to fix to wall for holding the wires at the top. This bracket is arranged so that wires varying greatly in size can be easily and

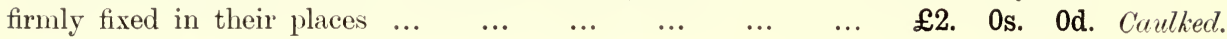

\section{Modulus of Rigidity of wires, Searle's Apparatus for} determining. This consists of two brass bars of square section weighing about 400 grammes each. They are suspended by means of hooks, the bars being connected by a known length of the wire whose modulus is required. Three wires of different rigidities are supplied with the apparatus

15s. 6d. Causator.

\section{E. Maxwell's Vibrating Needle for finding the Modulus} of Torsion of a wire. It consists of a horizontal brass tube into which four other equal tubes can slide, and thus fill up its whole length. Two of these tubes are

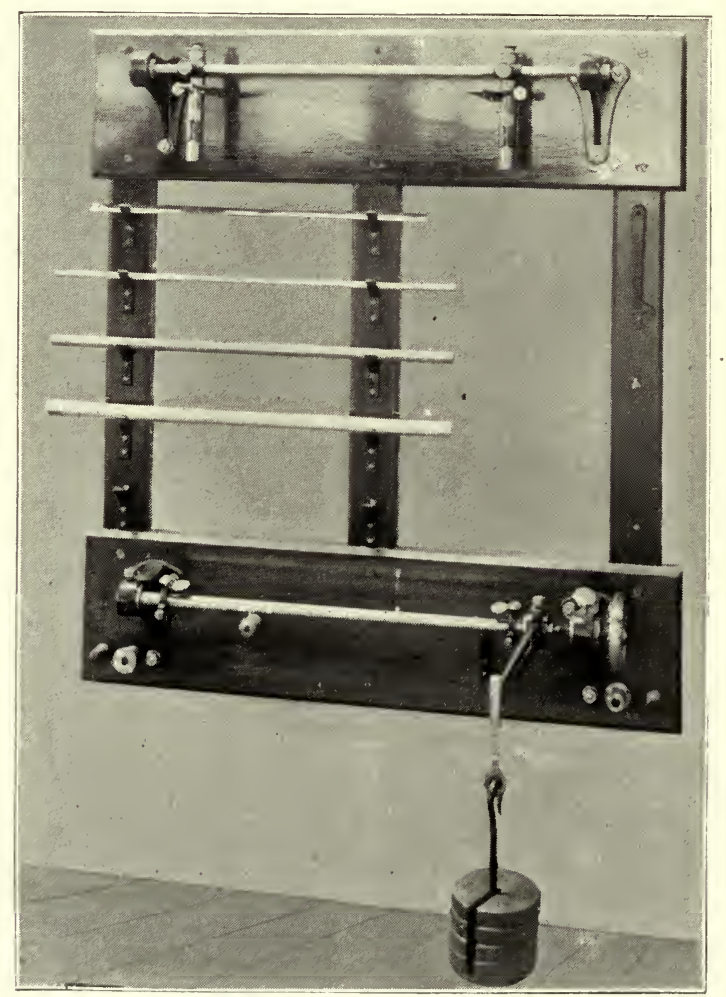

Fig. 34. No. 12.2. 
empty and two are full of lead. By placing the full or empty tubes nearest the centre the moment of inertia is changed, and observations of the corresponding periods of swing give the data required. Clamps for working with different wires are supplied (Fig. 32)

\section{E. Torsion of wires, Static observation of, also serving} for vibration experiment in measuring the modulus of torsion. The pulleys are mounted on ball bearings. See The Strength of Naterials, p. 86. (Fig. 33)

£12. 10s. 0d. Deposed.

$122 \mathrm{E}$. Apparatus for measuring modulus of torsion in rods up to $25 \mathrm{~mm}$. in diameter, and $64 \mathrm{~cm}$. long, with two reading telescopes and mirrors, for attachment to wall, complete with assortment of rods. See The Strength of

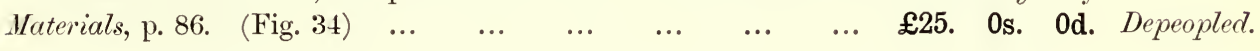

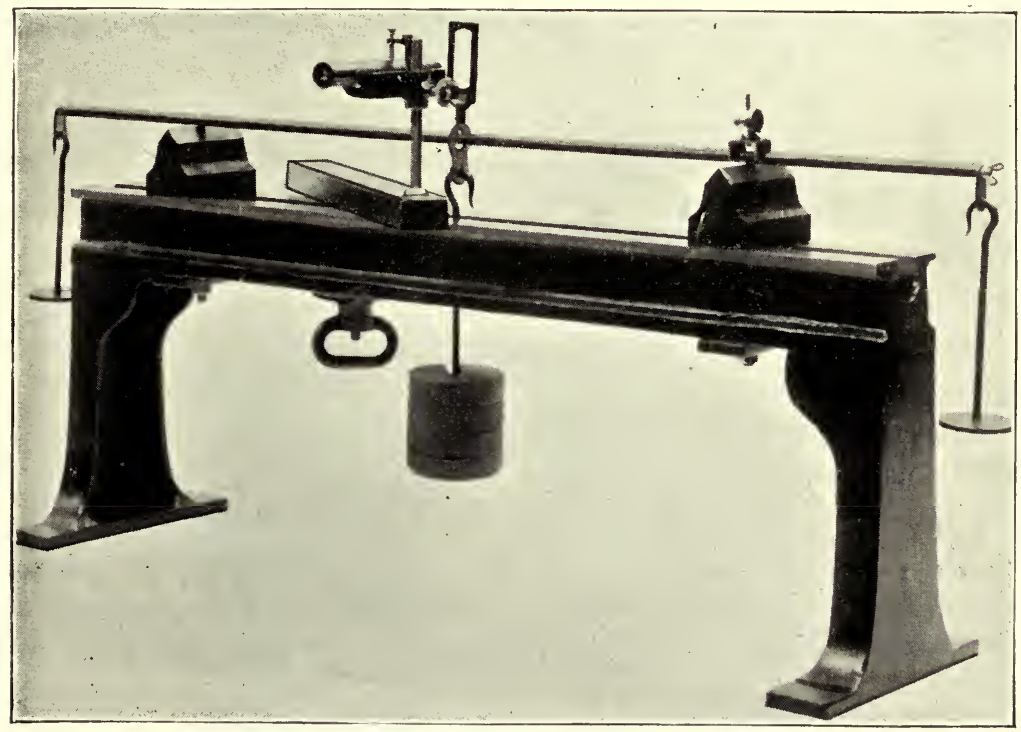

Fig. 35. No. 123.

\section{$123 \mathrm{E}$. Lathe-bed apparatus for experiments on the elastic}

bending of beams up to $125 \mathrm{cms}$. long, and for measurements of Young's Modulus by bending, fitted with reading microscope (Zeiss objective and micrometer eye-piece) and with jockey mirror for measuring the slope of the elastic curve, with assortment of beams. See The Strength of Materials p. 83. (Fig. 35)

£25. 0s. 0d. Denudation. 


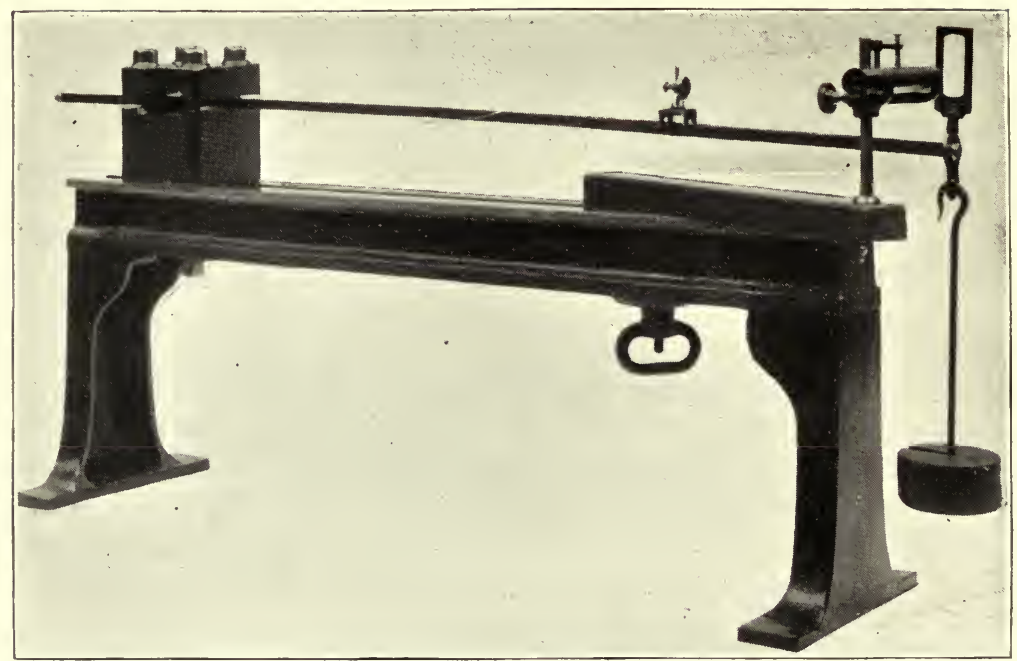

Fig. 36. No. 124 .

$124 \mathrm{E}$. Lathe-bed apparatus for experiments on the elastic bending of beams when arranged as cantilevers. The microscope and accessories are similar to those supplied with No. 123. (Fig. 36) $\quad \ldots \quad \ldots$

$£ 25$. 0s. 0d. Deoridized.

125 E. Lathe-bed apparatus. This instrument is a combination of Nos. 123 and 124.

The experiments which are usually: made on these two machines can be made on

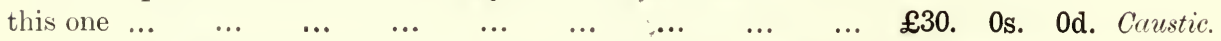

126. Apparatus for determining the Deflection of Beams. This consists of two cast-iron brackets which can be fixed to a wall; an iron bed, two movable supports with knife edges, cast-iron block for use with cantilever's, boxwood scale, stirrup, weight carrier, dial and pointer complete

See Perry's Applied Mechanics (Advanced) 1898 edition, p. 430.

£7. 10s. 0d. Celibacy.

$127 \mathrm{E}$. Apparatus for observing deflection of wooden rods about $110 \mathrm{~cm}$. long) loaded as beams, for attachment to wall £3. 10s. 0d. Detaglio.

$128 \mathrm{E}$. Beam with supports to show the re-actions at the ends under various arrangements of the load.

This consists of a graduated beam $100 \mathrm{cms}$. long resting on two knife edges supported by two spring balances. Weights are supported by stirrups which can be placed in any position on the beam

£4. 10s. 0d. Dinarchy. 
129 E. Continuous Beam Apparatus, with two platform balances, and loaded beam for experiments on the reaction at the supports of a continuous

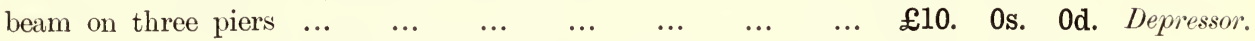

$130 \mathrm{E}$. Apparatus for measuring extension of wires to

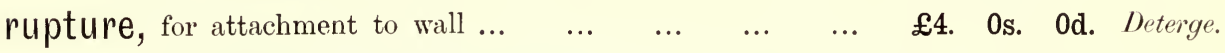

$131 \mathrm{k}$. Apparatus for observing extension and vibration of springs, with application to measure " $g$," with reading telescope, the whole being

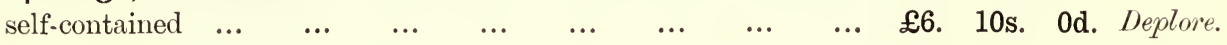

132. Spiral Springs, Apparatus for Demonstrating the Law of. This is similar to that shown in Perry's Applied Mechanics, 1898

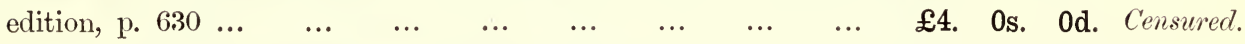

$133 \mathrm{E}$. Experimental determination of centre of gravity. This consists of a stand and clamp for suspending various shaped bodies for the experimental determination of their centres of gravity and moments of inertiabodies of various shapes are provided

£5. 0s. Od. Diacassia.

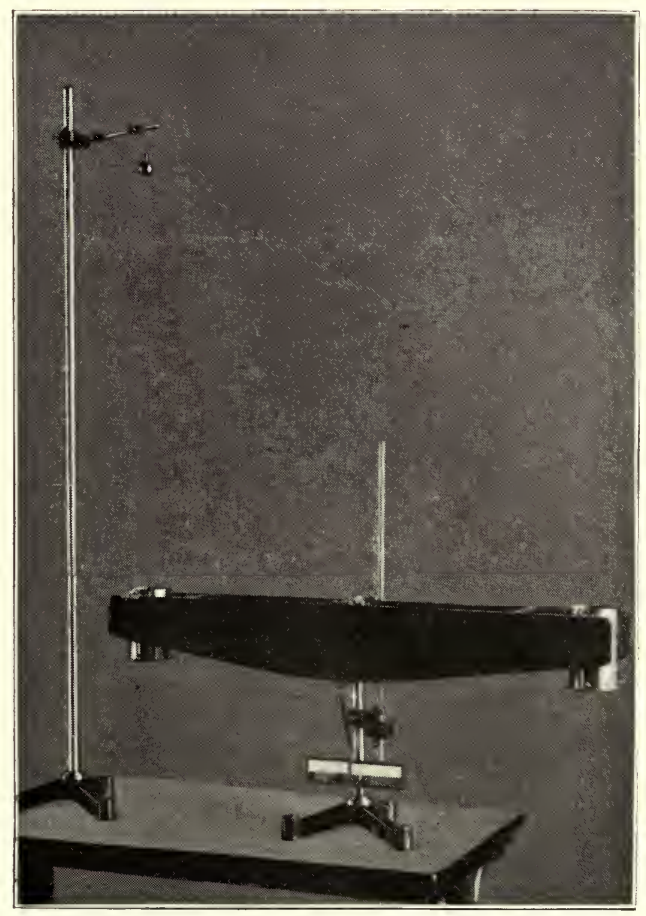

Fig. 37. No. 134. 
$134 \mathrm{E}$. Compound Ballistic Balance for determining the velocity of a body falling from a height by ballistic measurement. The body is suspended by a thread from a stand and hangs over one of the pans of the balance; the thread is then burnt, allowing the body to fall into the pan of the balance. (Fig. 3i) $\quad \ldots$

£15. Os. Od. Deprave.

135. Hicks' Ballistic Balance. (See Glazebrook's Mechanics, 1895 $\begin{array}{llllllllllll}\text { edition, p. } 80) & \ldots & \ldots & \ldots & \ldots & \ldots & \ldots & \ldots & \ldots & £ 3 . & 0 \text { s. } & \text { 0d. Cellar. }\end{array}$

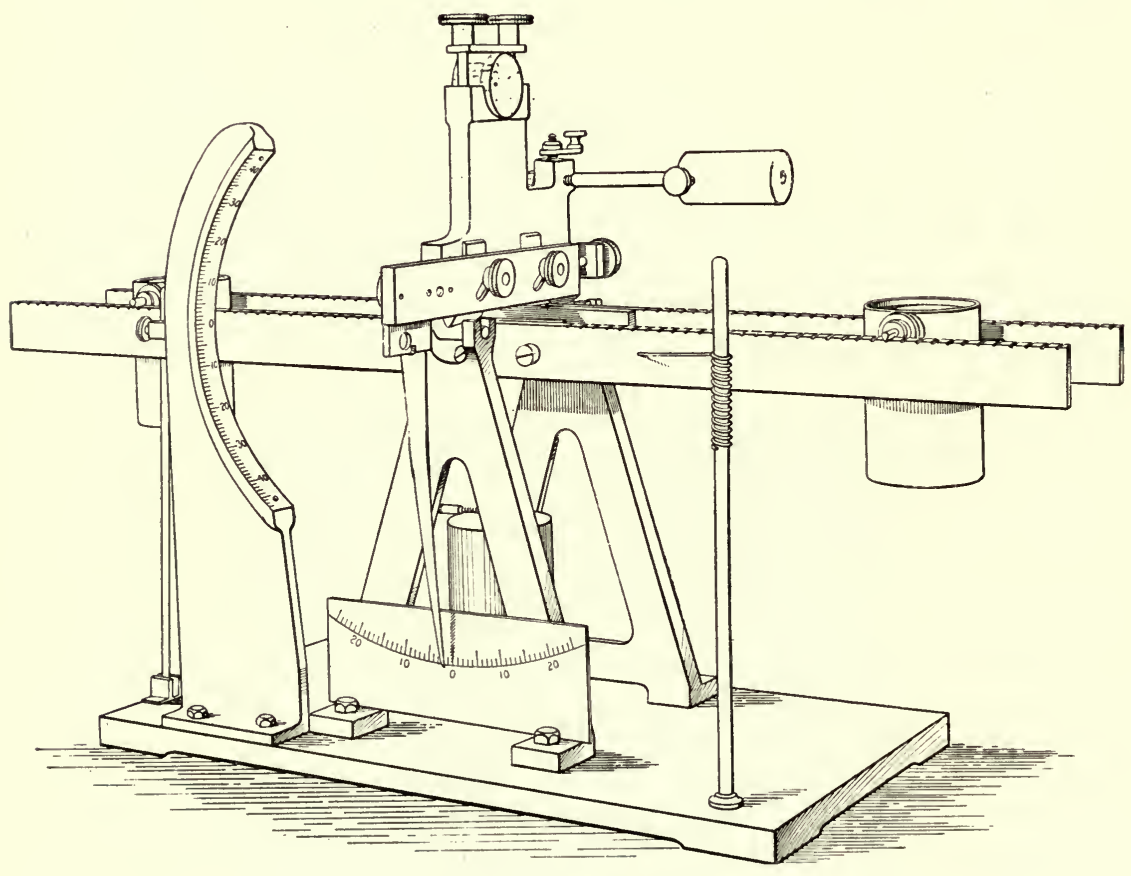

Fig. 38. No. 136.

136. Ballistic Pendulum. This is a modified form of that described in Glazebrook and Shaw's Practical Physics.

In this instrument an arrangement is provided in order that the momentum produced by a horizontal blow can be observed in addition to that given by a body falling from a height. The amplitude of swing can also be read by an arrangement of mirror and scale thus completing the analogy between observations with this instrument and those made with a ballistic galvanometer. (Fig. 38) $\quad . . \quad \ldots$

£13. 10s. 0d. Cellipore

137 E. Heavy Fly wheel on ball bearings for acceleration experiments, with tuning fork attachment. An arrangement is fitted for adjusting the pressure exerted by the writing style, and also for moving the fork laterally in order 
that several traces may be taken on the same strip of smoked paper. The design of the fork fitting has been improved in the more recent instruments, and is different

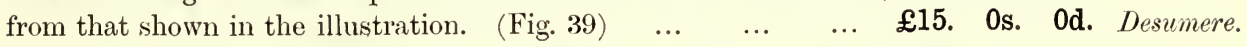

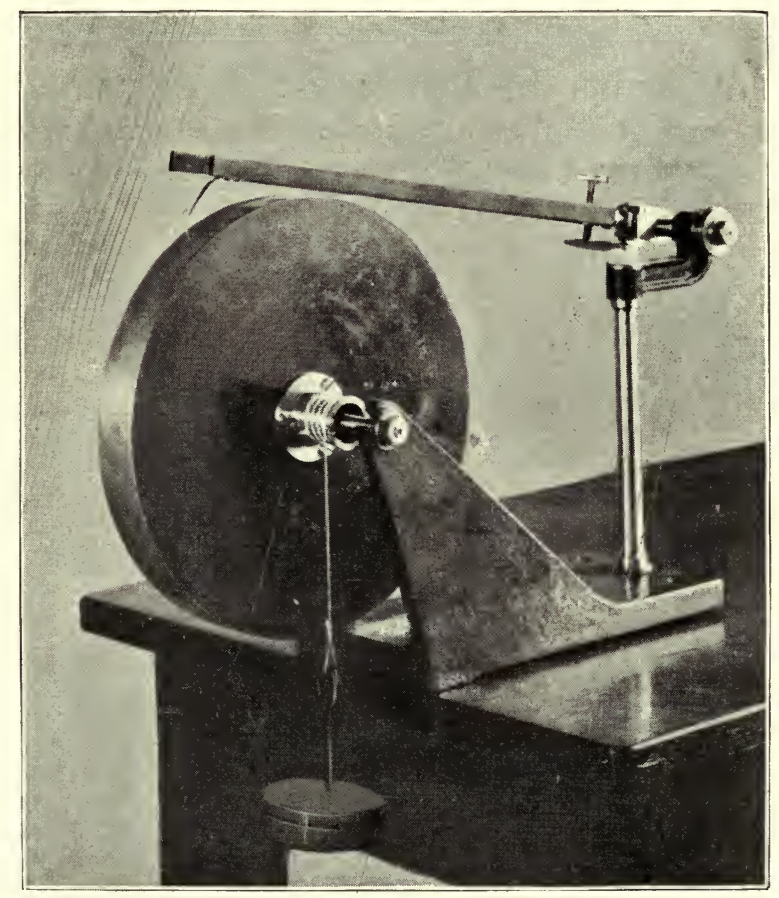

Fig. 39. No. 137 .

138 E. Rolling-ball Apparatus for experiments on Uniform Acceleration. The ball rolls down a grooved railway: the distance the ball rolls and the inclination of the railway may be altered at will. The water clock shews electrically the interval of time the ball has taken to roll down a given distance. With water

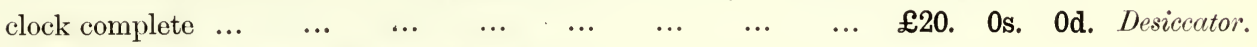

139. Atwood's Machine. Polished mahogany frame with levelling screws, large pulley running on friction wheels, automatic release, graduated scale,

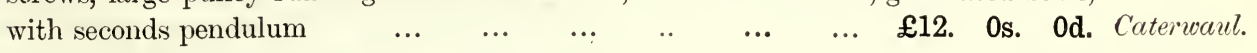

140. Atwood's Machine. Pulley and friction wheels are supported at the top of a strong steel tube about 2 metres long fixed to a heavy cast iron tripod, with three levelling screws. A millimetre scale is attached to the tube, and the platforms have slow motion screws. The trap door supporting the weight is

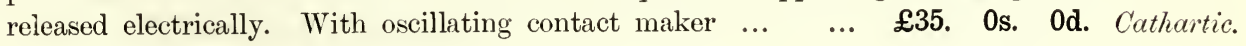


141. Morin's Machine, a modified form for demonstrating the laws of falling bodies. In this instrument the falling body is a cylinder to which a motion of rotation about its axis can be given by means of a handle and gearing. The cylinder falls rotating and a pencil fixed in a suitable position describes a parabola

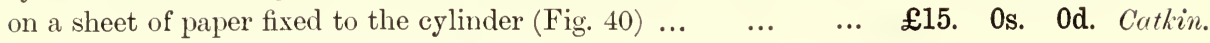

\section{Apparatus for Torricellian Experiments. This consists} of a tall glass ressel provided with three tubulures at different heights so that jets of water can be used under different pressures. The holes can be closed by means

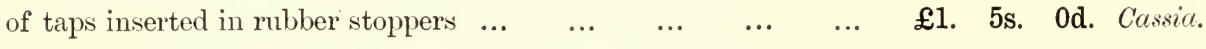

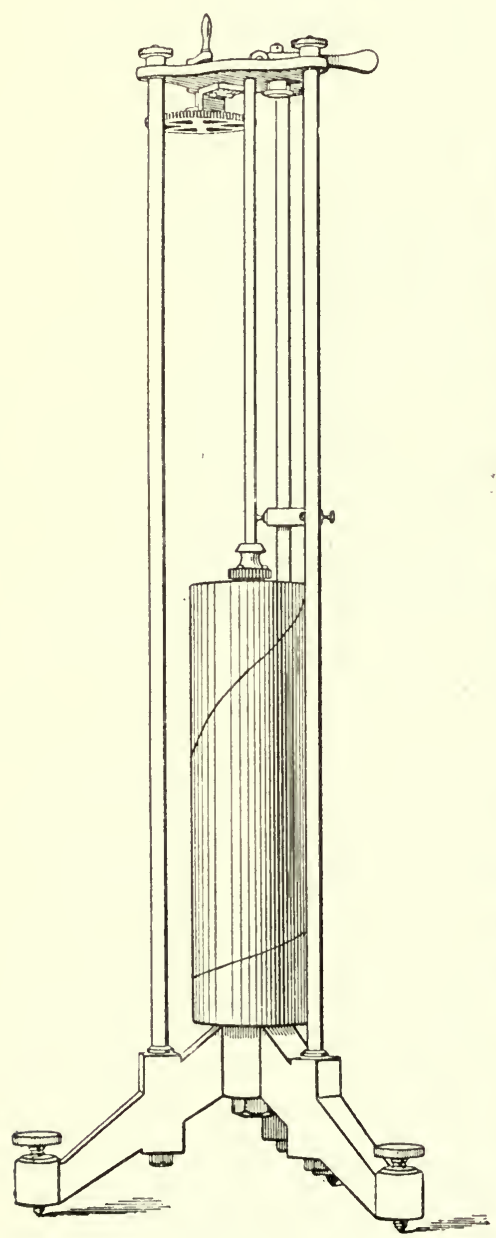

Fig. 40. No. 141.

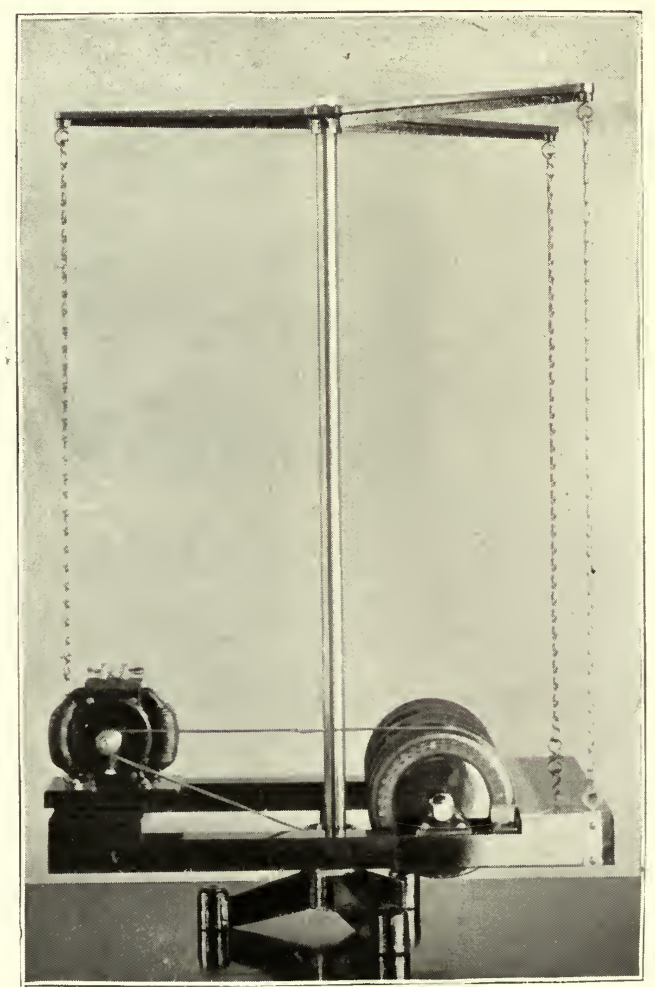

Fig. 41. No. 143. 


\section{$143 \mathrm{E}$. Apparatus for experiments on the balance of re-} volving machinery. This consists of a suspended frame with shaft carrying 5 discs, which can be loaded at pleasure, and which is driven by an electric motor. The distances of the dises from one another may be varied, as well as their angular positions. The relative positions of the discs are adjusted until the whole apparatus remains steady when running at a high speed. Complete with electric motor. (Fig. 41) ...

$144 \mathrm{E}$. Optical lever for measuring the thickness of plates, etc.

£10. 0s. 0d. Desperado.

$145 \mathrm{E}$. Bifilar suspension, Apparatus for experimental investigation

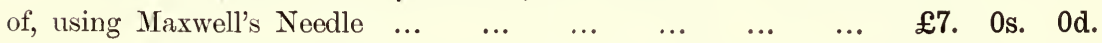

Diamondize.

146 E. Trifilar suspension, apparatus for finding experimentally the

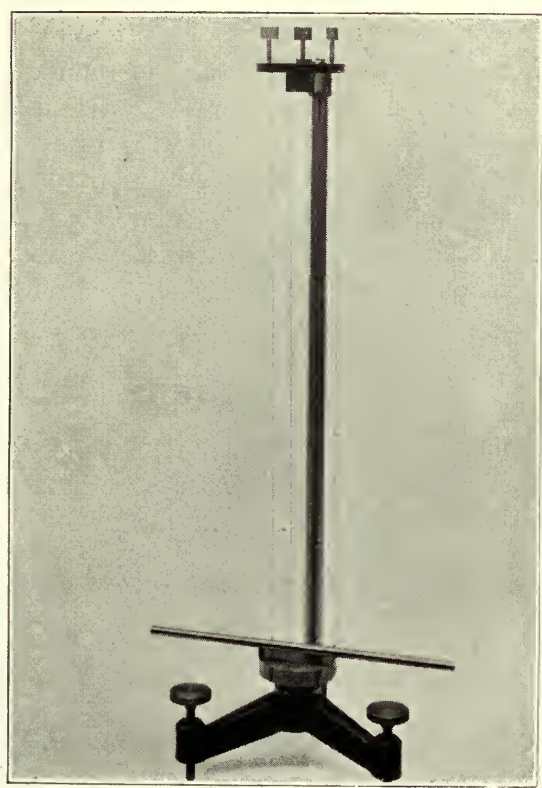

Fig. 42. No. 146. moment of inertia of rods, with assorted rods. (Fig. 42)

£7. 10 s. 0d. Diluvium.

147 E. Rod pendulum, with adjustable knife edge and stand complete, for experiments on the relation of the period of swing to the position of the axis of suspension ...

£4. 10s. 0d. Diatribe.

\section{E. Compound Pen-} dulum, Kater type, with adjustable bob, and fixed knife-edges, and with simple pendulum on the same stand $\ldots \quad \ldots \quad £ 5 . \quad 10$ s. $0 \mathrm{~d}$.

Deputize.

\section{E. Friction of a} cord on a pulley, self-contained apparatus for experiments on the. The arc of contact can be varied; the magnitude of the angle is found by help of squared paper mounted on a board behind the pulley, by use of which the inclination of the cord is read off ...

£5. 0s. 0 d.

Didactical.

150 E. Composition of moments, self-contained apparatus for experiments on the. Consisting of a horizontal table with freedom to revolve about a vertical axis, which takes up a position of equilibrium under the action of three moments produced by adjustable forces

£5. 0s. 0d. Dieresis. 
151 E. Funicular Polygon. Self-contained apparatus for examining the form assumed by a hanging cord under any distribution of loads

£4. 0s. 0d. Dietdrink.

152 E. Triangle and polygon of forces, Self-contained apparatus for experiments on the...

£5. 0s. 0d. Digital.

153. Parallelogram of forces, Apparatus for demon-

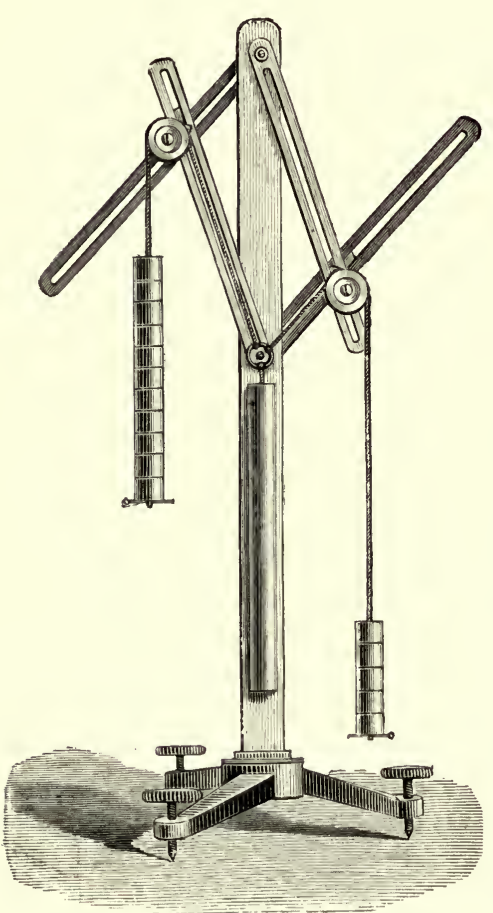

Fig. 43. No. 153. strating the, in brass. See Aldous's Physics, p. 61 (Fig. 43) ... £4. 0s. 0d.

Cemental.

\section{E. Centrifugal force Ma-} chine, for quantitative measurements of centrifugal force.

A brass weight is attached by means of a steel rod and lever to an iron diaphragm forming one side of a mercury reservoir. The system carrying the weight and reservoir is made to ratate by means of a pulley and hand wheel. As the speed of rotation is increased the mercury rises in the glass tube owing to the centrifugal force exerted by the brass weight. The distance of this weight from the centre can be varied as desired. A counter shows the number of revolutions made by the system $\quad \ldots \quad £ 15$. 0s. 0 d. Dilater.

\section{$155 \mathrm{E}$. Inclined plane for re-} solution of forces and for experiments on friction. The inclined surface is made of glass

£5. 10s. 0d. Dilatorily.

\section{$156 \mathrm{E}$. Inclined plane for ex-} periments on the velocity of a rolling cylinder, with cylinder and scale of distances ... £4. 0s. 0d. Dillisk.

157. Jolly's Balance, for determination of specific gravities. Mounted on tripod stand with levelling screws and arrangement for raising and lowering, with mirror scale

$£ 3.0$ s. 0 d.

158. Sprengel Air-Pump. This pump may be used with or without a mechanical pump. The auxiliary pump is attached immediately above the air trap. The ends of the three fall tubes dip into self-contained tubes of mercury, thus preventing the suspended column from rising, should it be necessary to leave the pump with the vacuum on.

A degree of vacuum equal to two millionths of an atmosphere can be obtained

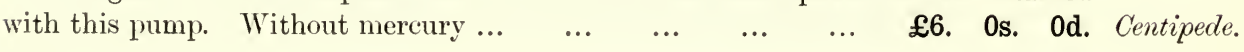


159. Fleuss' Patent Vacuum Pump, Single cylinder, with lever "No. 1 size."

160. Do. do. with two cylinders and heavy flywheel "Duplex A"

$£ 20$. 0s. Od. Gaol.

It is sometimes advisable to have a $\mathbf{V}$-shaped groove cut in the fly-wheel for $\begin{array}{llllllllll}\text { driving with a motor } \ldots & \ldots & \ldots & \ldots & \ldots & \ldots & \ldots & \text { Extra } & 7 \mathrm{~s} . & 6 \mathrm{~d} \text {. }\end{array}$

\section{Humphrey's Apparatus for Recording Variations in} the Speed of a Gas-Engine. This consists of a drum 165 mms. in diameter which is connected by means of a universal joint, especially designed to avoid backlash, to the shaft of the Gas Engine under trial. A time marker which is electrically connected to a tuning fork is carried along the face of the drum by means of a screw. From the records obtained the variations in speed can be determined with great accuracy.

$\begin{array}{llllllll}\text { Price with time marker complete } & \ldots & \ldots & \ldots & \ldots & £ 20 . & 0 \text { s. } & 0 \text { d. }\end{array}$

For prices of tuning forks and stands see p. 18. A fork of 100 vibrations per sec. will be found suitable for this experiment.

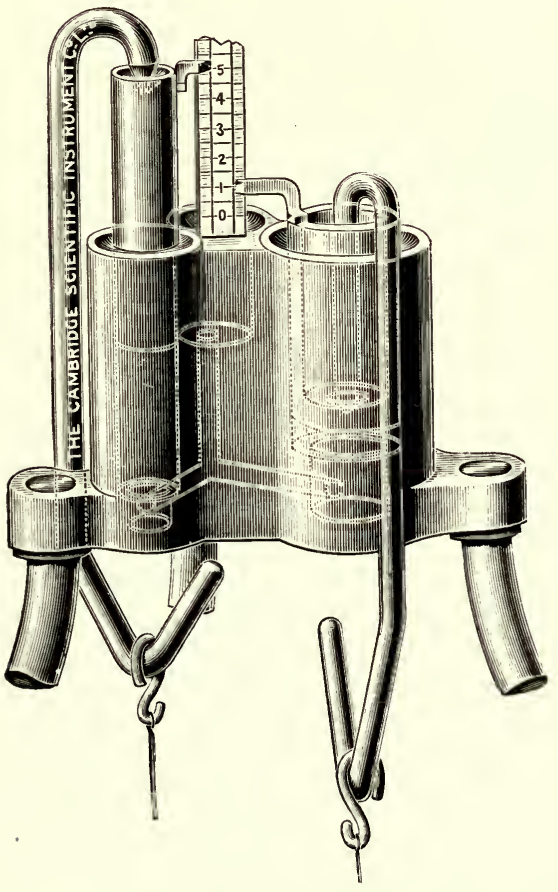

Fig. 44. No. 163.

162. Inertia Solids. These consist of masses of brass and gun metal of various accurate geometrical shapes, such as spheres, discs, tubes, etc., so arranged that a small clamp may be fixed to various parts of them, they may thus be suspended, each in turn, from the end of a fine wire. Torsional oscillations being then set up, the moments of inertia may be compared by noting the periods of oscillation $\quad \ldots \quad \ldots \quad £ 10.0$. 0 s. 0d. Gardyloo.

\section{Hydrostatic Para-}

dox. Apparatus to illustrate and to prove the Transmissibility of Fluid Pressure. It consists of two cylinders into which two pistons fit, the face area of one being four times that of the other. Whatever total pressure acts on the smaller is exerted fourfold on the larger piston if the fluid transmits the pressure equally to all parts. An index on each piston shows its rise or fall on a scale. The apparatus is supported by means of a tripod stand (Fig. 44). See Aldous's Physics, p. 165.

£6. 10s. 0d. Cessment. 


\section{Motors.}

164. "Thirlmere" Patent Water Motors, for pressures orer $20 \mathrm{lbs}$. per square inch. For efficiency it is essential that the motors should run at the speed given in the list (Fig. 45) :--

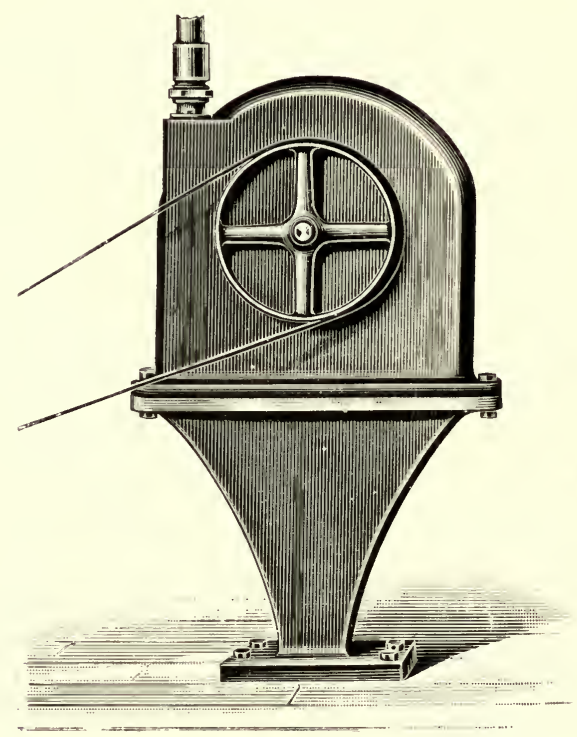

Fig. 45. No. 164 .

\begin{tabular}{|c|c|c|c|c|c|c|c|c|}
\hline $\begin{array}{l}\text { No. } \\
\text { Size. }\end{array}$ & $\begin{array}{l}\text { Approxi- } \\
\text { mate } \\
\text { B.H.p. at a } \\
\text { pressure of } \\
40 \text { lbs. per } \\
\text { sq. inch. }\end{array}$ & $\begin{array}{l}\text { Approxi- } \\
\text { mate } \\
\text { Consump- } \\
\text { tion in } \\
\text { Gallons } \\
\text { per } \\
\text { minute. }\end{array}$ & $\begin{array}{c}\text { Revolutions } \\
\text { per minute. }\end{array}$ & $\begin{array}{c}\text { Diameter } \\
\text { of } \\
\text { driving } \\
\text { Pulley } \\
\text { in } \\
\text { mm. }\end{array}$ & $\begin{array}{l}\text { Size } \\
\text { of } \\
\text { Inlet } \\
\text { Pipe } \\
\text { in } \\
\mathrm{mm} .\end{array}$ & Price. & $\begin{array}{l}\text { Extra } \\
\text { for Re- } \\
\text { gulating } \\
\text { Valve } \\
\text { and } \\
\text { Lever. }\end{array}$ & \\
\hline 000 & $\frac{1}{80}$ & $\cdot 8$ & 2000 & 32 & 12 & £1. 10 s. 0 d. & 10s. $0 \mathrm{~d}$. & 1 fteract. \\
\hline 00 & $\frac{1}{40}$ & $1 \cdot 1$ & 1900 & 32 & 12 & $£ 2 . \quad 2$ s. 0 d. & 10s. $0 \mathrm{~d}$. & Igainst. \\
\hline 0 & $\frac{1}{16}$ & $2 \cdot 75$ & 1200 & 54 & 16 & £3. 3s. 0 d. & 12s. $6 \mathrm{~d}$. & Agarick. \\
\hline 1 & $\frac{1}{8}$ & $5 \cdot 5$ & 800 & 76 & 19 & £5. $5 \mathrm{~s} . \quad 0 \mathrm{~d}$. & $15 \mathrm{~s} . \quad 0 \mathrm{~d}$ & Agazed. \\
\hline 2 & $\frac{1}{4}$ & 11 & 600 & 82 & 25 & £8. 10 s. 0 d. & 20 s. 0 d. & Agency. \\
\hline 3 & $\underset{1}{1}$ & 22 & 400 & 108 & 38 & $£ 12.10$ s. 0 d. & 30s. 0 d. & Aggrate. \\
\hline $3 \mathrm{D}$ & $\overline{1}$ & 44 & 400 & 108 & 51 & £16. 0s. 0d. & 40s. 0 d. & Aggressor. \\
\hline $3 \mathrm{~T}$ & $1 \frac{1}{2}$ & 66 & 400 & 152 & 51 & $£ 22 . \quad 0$ s. 0 d. & 50s. $0 \mathrm{~d}$ & Agnate. \\
\hline
\end{tabular}

The above prices are subject to fluctuations in the metal market.

The first four sizes are fitted with grooved pulleys for cord driving; the larger sizes have flat pulleys for belt. 
165. Electric Motors. Lundell Pattern. These motors are suitable for driving Recording Drums, etc., they are compact and practically noiseless. Those of $\frac{1}{16}$ th and $\frac{1}{8}$ th H. P. can be driven by a small battery. The motors develop their maximum efficiency when driven at 115 volts (direct current) but they will work well between 90 and 140 volts (Fig. 46).

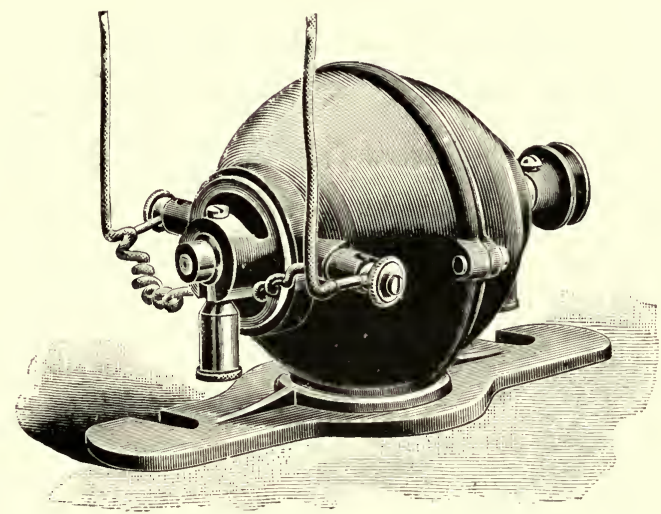

Fig. 46. No. 165 .

$\begin{array}{cccc}\text { H.P. } & \text { Volts. } & \begin{array}{c}\text { Revolutions per } \\ \text { minute. }\end{array} & \begin{array}{c}\text { Diameter of } \\ \text { Pulley in } \mathrm{mm} .\end{array} \\ \frac{1}{16} & 115 & 1900 & 2.5 \\ \frac{1}{8} & 115 & 1800 & 38 \\ \frac{1}{6} & 115 & 1800 & 38\end{array}$

Price.

£5. 10s. 0d. Action Motor. £6. 10s. 0d. Acuity Motor. £8. 0s. Od. Acutely Motor.

Motors above $\frac{1}{4}$ H. P. inclusive, require self-oiling bearings and a starting switch.

$\begin{array}{cc} & \begin{array}{c}\text { Ampères } \\ \text { at 115 }\end{array} \\ \text { H. P. } & \text { Volts. } \\ \frac{1}{4} & 2 \cdot 2 \\ \frac{1}{2} & 4 \cdot 3 \\ 1 & 8 \cdot 7\end{array}$

$\begin{array}{ccc}\begin{array}{c}\text { Revs. per } \\ \text { minute. }\end{array} & \begin{array}{c}\text { Diameter } \\ \text { of Pulley } \\ \text { in mms. }\end{array} & \begin{array}{c}\text { Price } \\ \text { of } \\ \text { Notor. }\end{array} \\ 1700 & 70 & £ 13 \\ 1500 & 89 & £ 20 \\ 1300 & 114 & £ 23\end{array}$

Price of starting switch.

£1. 15s. 0d. Adalite Motor. $£ 1.15 \mathrm{~s}$. 0d. Aduunt Motor. £3. 0s. 0d. Addice Motor. 


\section{SOUND.}

166. Kymoscope for demonstrating Wave Motion. This instrument was designed by Professor Anderson Stuart. A metal tube is coiled into the form of the thread of a horizontal screw and glass manometer tubes with their upper ends open are connected to the highest points of each coil ; they are close together and the level at which a coloured liquid stands in them shews the pressure in each coil. By compressing either of two indiarubber balls connected with the apparatus the coloured liquid forms a wave-shaped curve which moves forward. By compressing both together the interference of two waves can be shown.

For greater precision a pump without valves can be used in place of the indiarubber balls. The construction of the pump is such that both the phase and the amplitude of the waves can be altered absolutely and relatively.

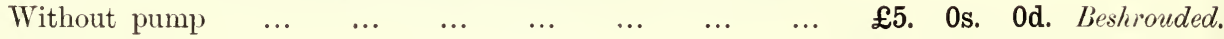

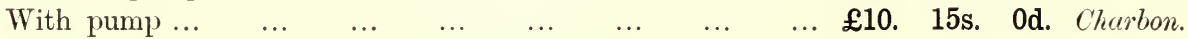

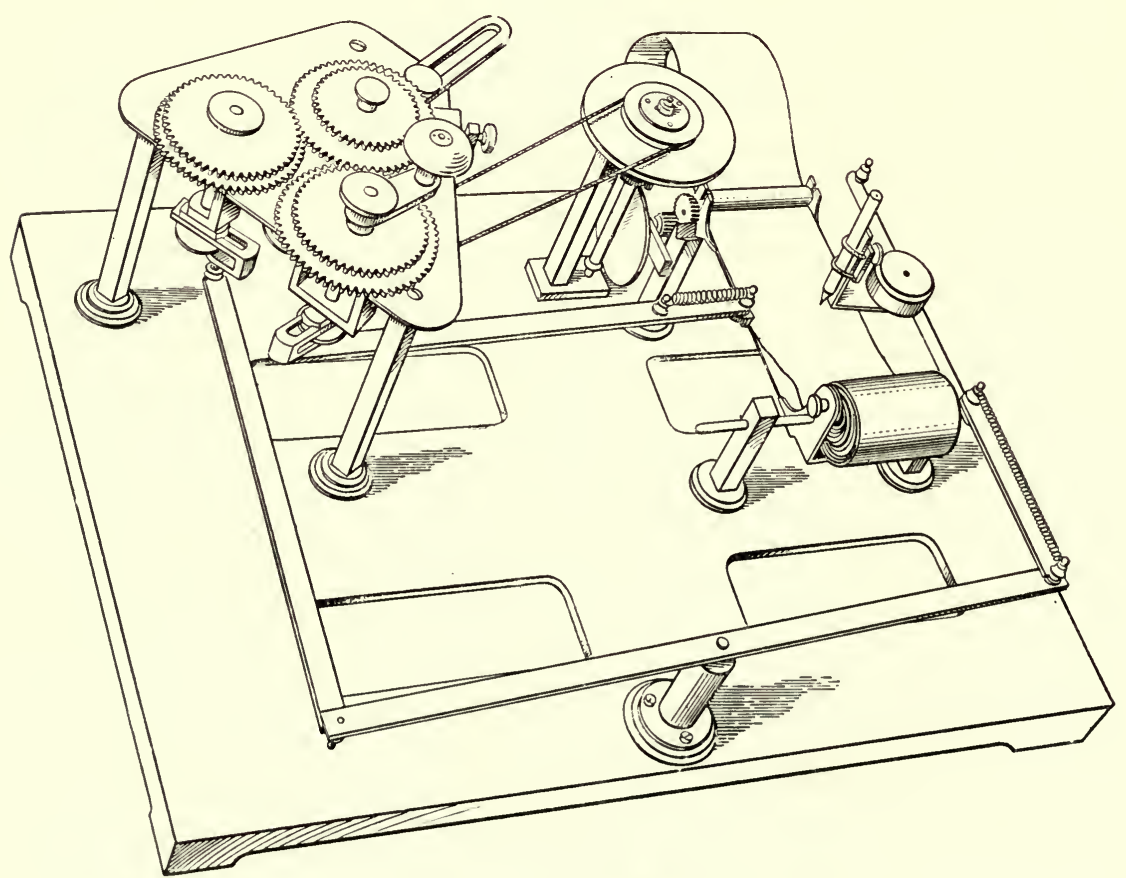

Fig. 47 . No. 167 . 
167. Harmonograph. This instrument draws a curve compounded of two simple harmonic motions on a moving strip of paper. It is similar to Donkin's Harmonograph, see Proc. Royal Soc. Vol. 22, p. 196.

Motion is communicated to the pencil by means of two adjustable cranks and long connecting rods. The speed of the paper can be varied at pleasure and sets of toothed wheels are supplied which enable various ratios in the speed of the two cranks to be obtained. Wheels are also provided to illustrate the beats produced

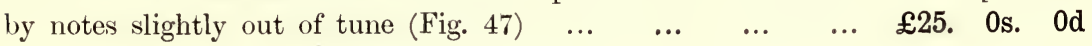

Chargeship.

168. Monochord. Made of polished mahogany and mounted on iron feet. There are 4 strings, two of which can be strained by means of weights

£4. 10s. Od. Charlock.

169. Phoneidoscope. The invention of Mr Sedley Taylor for observing the coloured figures which are reflected from thin liquid films in sonorous vibration. It consists of three metal discs, pierced respectively by triangular, square and circular apertures across which flat soap-sud films can be easily formed. See Proceedings of the Royal Society, Vol. xxvir. No. 189, pp. 71--76 and Nature for March 28th, 1873

170. Resonance Tubes of Adjustable Length. Two vertical glass tubes about one metre long are fixed to two boards with their open mouths upwards. These can slide up and down in a wooden upright and can be clamped in any position. Their lower ends are connected together by an indiarubber tube wbich does not interfere with their independent movement. When the tubes are partially filled with water their effective length can be readily altered by raising or lowering one of them. A scale is fixed behind each tube, in order that the distance of the surface of the water from the open mouth of the tube can be obtained

£3. 15s. 0d. Chatoyant.

171. Galton's Whistle. This consists of a whistle of very small bore with an arrangement for varying its length by an adjustable plug. It is sounded by squeezing air out of a small indiarubber bag. An ivory scale of wedge shape is supplied for measuring the length of the whistle corresponding to a given note.

£1. 5s. 0d. Belauded.

The whistle can also be arranged for laboratory use, the air being forced from an air-bag at a constant pressure by means of weights. The length of the whistle is varied by means of a long lever, and the pipe-length read off' on a magnified scale.

172. Apparatus complete with bellows, long lever and whistle

£6. 10s. 0d. Belfires.

\section{Tuning Fork Apparatus for Producing Lissajou's}

Curves. This consists of two tuning forks, one horizontal and the other vertical, both carrying small mirrors. The forks are mounted as shown in Fig. 48 and are maintained in vibration by means of electro-magnets.

Stand without forks, but including electro-magnets ... $\quad .$.

Apparatus complete with two calibrated forks carrying mirrors

£5. 5s. 0d. Chatwood. £8. 8s. Od. Chebako. 
Tuning Forks for use with the above apparatus, for producing Lissajou's curves of various differences of phase:--Seven forks giving phase differences of $1: 2,1: 3$,

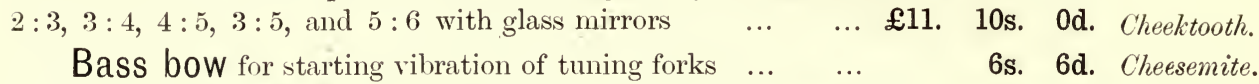

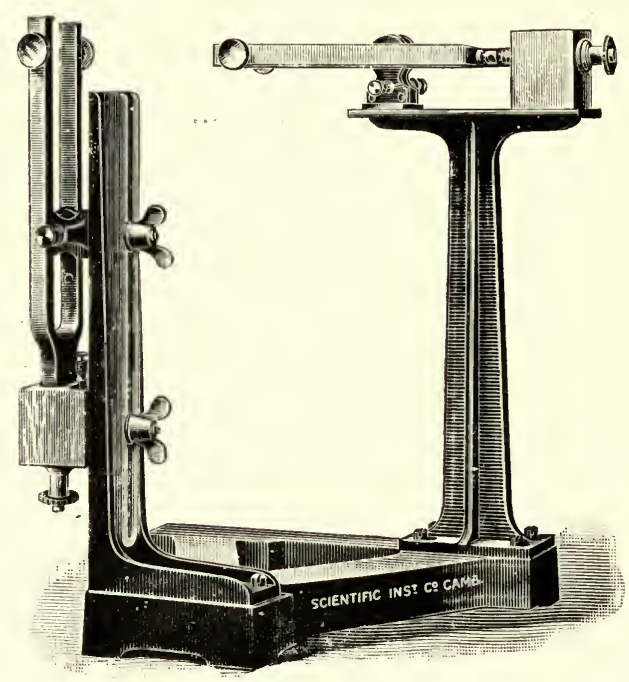

Fig. 48. No. 173.

174. Adjustable Tuning Fork Stand. The vibration of the tuning fork is electrically maintained, and the instrument is suitable for producing Lissajou's Curves and for many other experiments. The vertical adjustment makes it convenient for recording on the smoked paper of a Recording Cylinder. A gum metal block is clamped by a screw to a vertical rod fixed to a heavy cast iron tripod foot, giving vertical adjustment. The metal frame, carrying the tuning fork and electro-magnet, can be fixed in three different positions by means of a milled head screw. The fork can be fixed horizontally or vertically. The contact is made by a platinum wire fixed to one prong of the fork striking against the platinum faced head of a screw. A mercury cup is supplied which can be used instead of the platinum contact when the fork is horizontal. With mirrors fixed to the forks, a pair of these instruments are most suitable for making Lissajou's

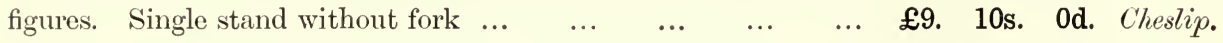

175. Melde's Apparatus. A gut string is made to vibrate under the influence of a tuning fork, the vibrating segments of the string being distinctly visible. The instrument is mounted on a mahogany base $\quad \ldots \quad £ 2 . \quad$ os. $\quad$ od.

Cheesevat.

176. Melde's Apparatus provided with a powerful electrically driven tuning fork to which a platinum wire is attached. This wire can be made incandescent by means of an electric current thus rendering the vibrations visible $\begin{array}{llllllll}\text { to a large audience. } & \text { Platinum wire, extra } \ldots & \ldots & \ldots & \ldots & £ 6 . & 0 \text { s. } & \text { 0d. }\end{array}$ 


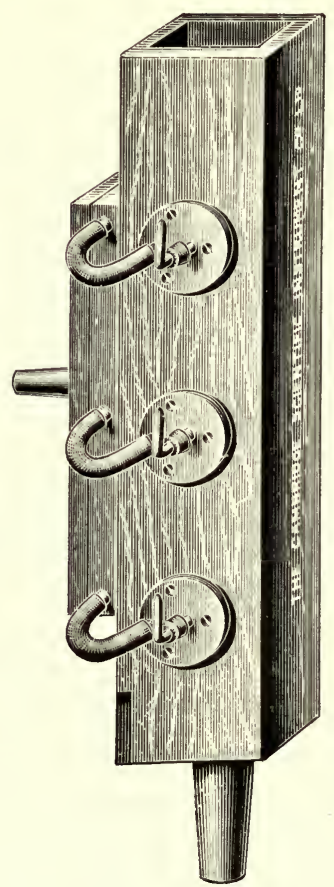

Fig. 49. No. 177.

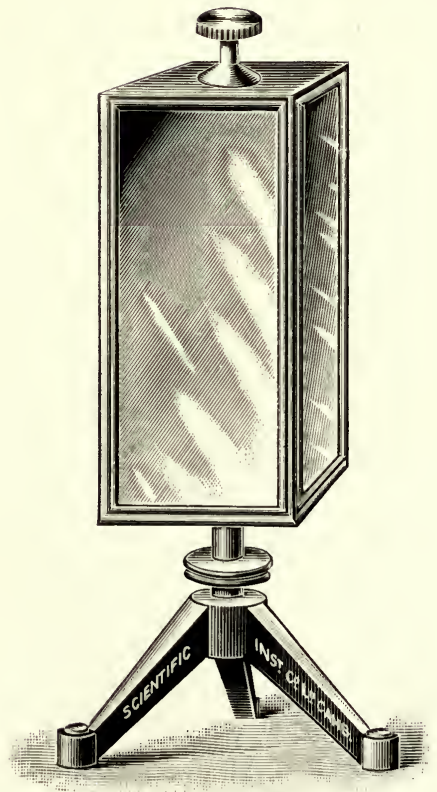

Fig. 50. No. 178.

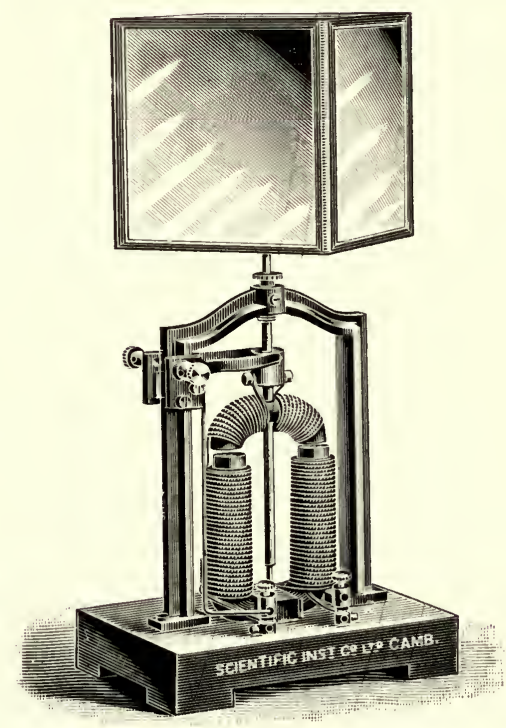

Fig. 51. No. 179. 
177. Koenig's Pipe for showing the nodes of vibrations. It is provided with three gas flame manometers (Fig. 49)

£2. 10s. 0d. Chevying.

\section{Rotating Mirror on Stand (Fig. 50) f. $\quad$ \&2. 0 0s. Od. Chidingly.}

179. Do. Do. With electric motor for giving rotation (Fig. 51)

£3. 10s. 0d. Chiliagon.

180. Syren. For measuring the number of vibrations made by a given note

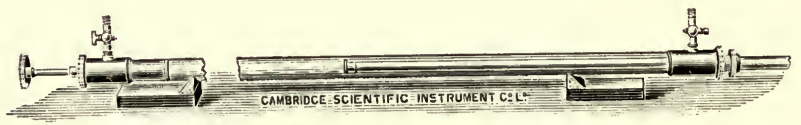

Fig. 52. No. 181.

181. Kundt's Apparatus. For producing dust figures in a glass tube to show the nodes and loops. It may also be used for finding the velocity of sound.

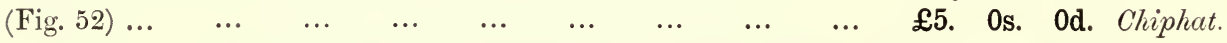

\section{Tuning Fork and Resonator with Adjustable Mouth.} This consists of a glass vessel on the top of which is placed a brass plate with an aperture the size of which can be varied. A scale showing the width of aperture in $\mathrm{mm}$. is provided. The vessel can be filled with water thus varying the length of

12s. 6d. Girrock. 


\section{LIGHT}

183. Bunsen Photometer. This instrument is designed for laboratory use. It consists of a horizontal bar of mahogany resting on supports and carrying a boxwood scale. A sight box mounted on a carriage carrying a pointer is moveable along the bar. Carriers are provided for a standard candle, an electric lamp, and a gas burner. Two shade screens are provided

£6. 10s. 0d. Chirurgeon.

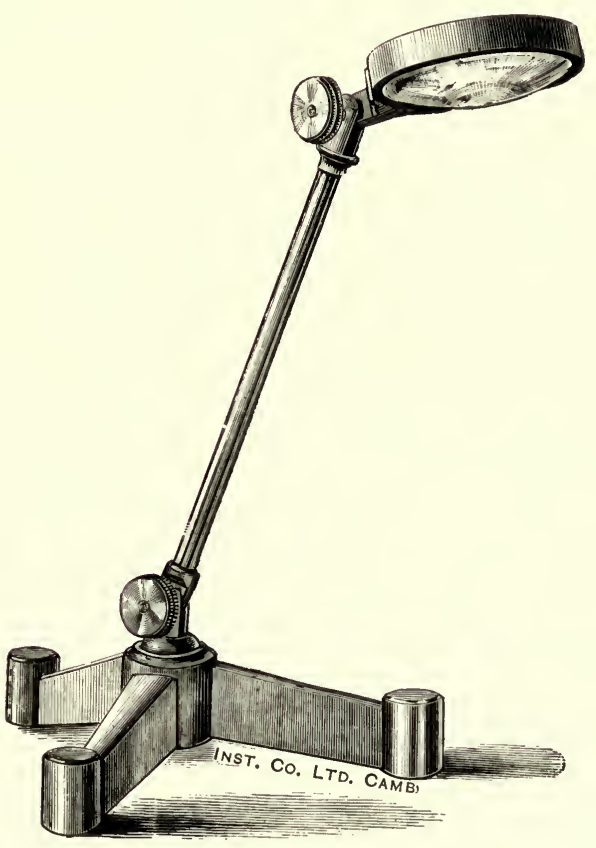

Fig. 53. No. 184.

184. Condensing Lens. A double convex lens, $75 \mathrm{~mm}$. in diameter and $75 \mathrm{~mm}$. in focal length, is supported by a flexible arm, giving great freedom of movement. The lens can be fixed in any required position by clamping the joints in the arm. The base consists of a heavy cast-iron tripod $\quad \ldots \quad £ 1 . \quad 15 \mathrm{~s}$. 0d. Gastromyth

The instrument supplied is an improved form to that shown in Fig. 53.

185. Optical Lantern. This consists of a Russian iron lantern fitted with $102 \mathrm{~mm}$. condenser and achromatic projection lens.

The lamp supplied with the lantern is a hand-fed arc lamp of specially strong and rigid construction. The type of clamp holding the carbons enables them to

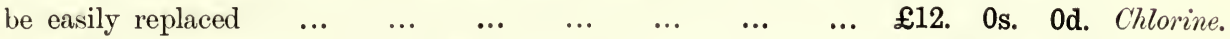

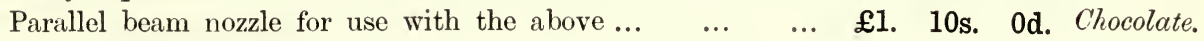


186. Wheel of Lenses, for analysing the oscillations of an electric spark. The wheel consists of a brass disc

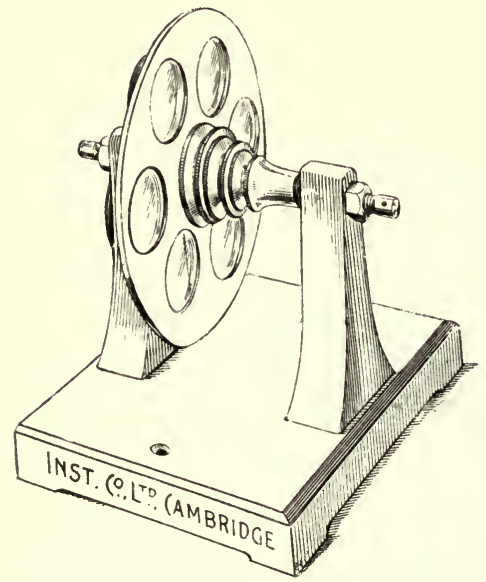

Fig. 54. No. 186. containing six achromatic lenses of about $150 \mathrm{~mm}$. focal length. The lenses are in the plane of the disc and are arranged in pairs thus : one pair are equidistant from the axis and are at opposite sides; the next pair are again equidistant but are slightly further from the axis, and the third pair are a little further away still. The wheel is mounted on a horizontal spindle and is carefully balanced. A cord from a suitable motor drives it at a very high speed. The oscillating spark is formed on one side of the wheel, and the image is focussed on a screen or a photographic plate on the opposite side. When the wheel rotates the image of the spark is drawn out into a beaded band, but as it is possible to turn the disc so fast that it has moved through nearly half a turn during the existence of the spark, each lens projects a beaded arc of nearly half a turn in extent. As the lenses are displaced slightly the separate ares clear each other. Therefore if the plate is large enough to take an arc of $60^{\circ}$, the whole record of the spark will be found upon it. See "Notes on the Oscillating Electric Spark," by C. V. Boys, F.R.S., in the Phil. Mag. of Sept. $1890 \quad \ldots \quad £ 5$. 15s. Od.

187. Colour Mixer. Coloured dises of cardboard are supplied with the instrument. The light from the different colours can be mixed in varying proportions

\section{Laws of Reflection and Refraction, Apparatus for}

demonstrating. This consists of a vertical graduated metal circle with two movable arms which can be set at any angle. One arm carries a mirror which reflects light from a source on to either another mirror, or on to a liquid placed in a glass trough which can be fixed at the centre of the divided circle. Two horizontal scales are also attached to the instrument in order that the sines of the incident and refracting angles can be compared. The instrument is mounted on a cast-iron

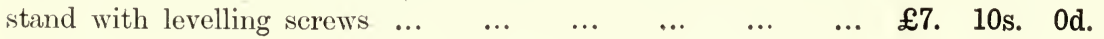

Choheberry.

189. Optical Bench. The bed of this instrument is similar to that used with Melloni's Apparatus (p. 63). It has a finely-divided scale and carries three pillars, the blocks of which have geometrical bearings upon the bed surfaces. Each of the pillars has a rack and pinion for vertical adjustment, and one is capable of movement at right angles to the bed. All three are provided with 
verniers. Two pillars are capable of slow motion round a horizontal axis. The third pillar carries a Fresnel Micrometer Eye-piece. The bench is supplied with 1 slit, 7 slides for diffraction experiments, lens holder, electric incandescent lamp, gas burner, extra pillar carrying lens and Fresnel bi-prism ... £57. 10s. 0d.

Prices for accessories for use with the above quoted on application.

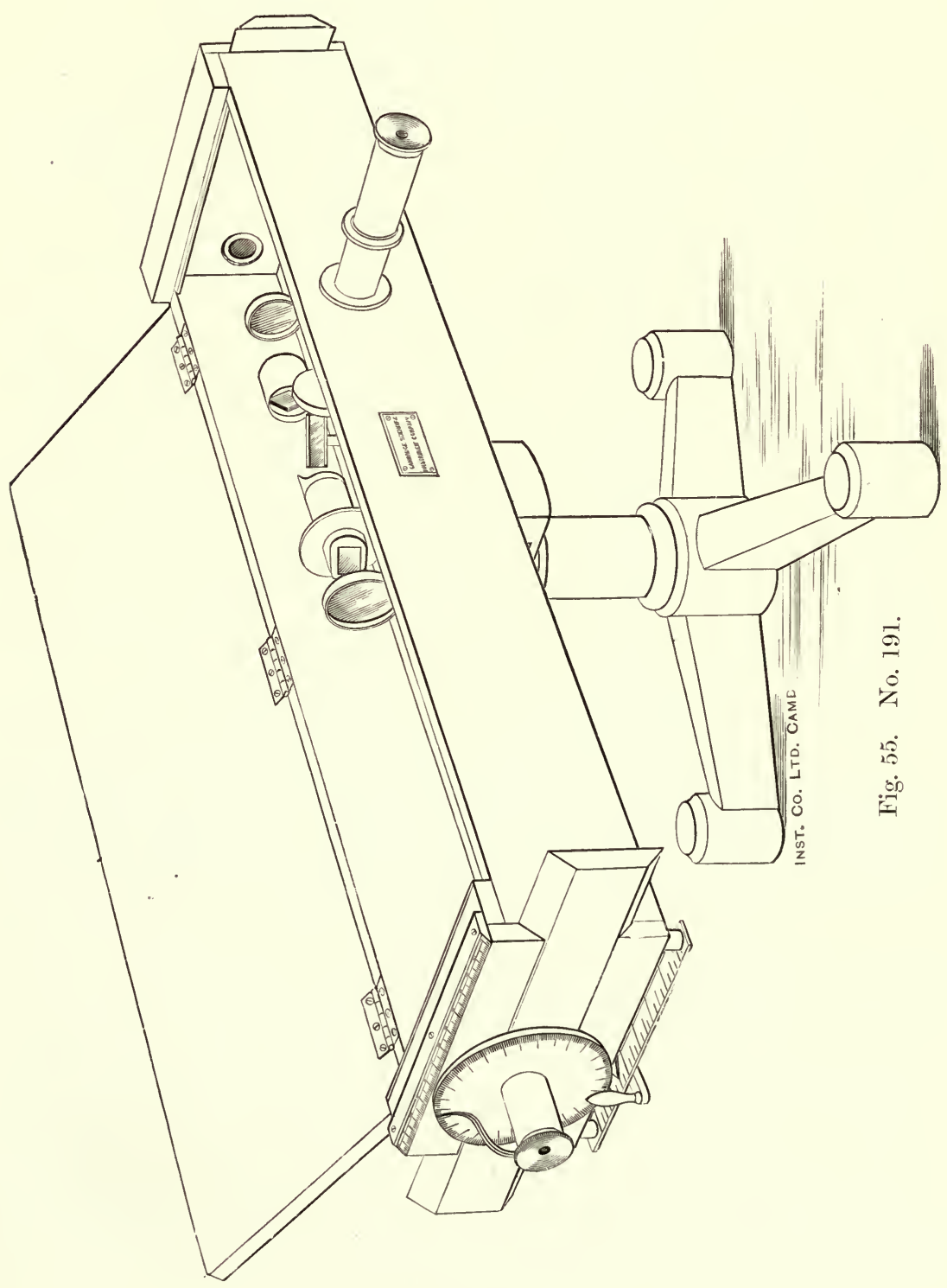


190. Optical Bench. Students' pattern. The bed is made of mahogany and the scale of boxwood. Three carriers are provided. The apparatus is supplied with an eye-piece with cross wires, a wire screen, opaque and ground glass screens, a lens holder, gas burner and a set of lenses $\ldots$ £5. 10s. 0d.

Gelable.

191. Spectrophotometer. A modification of the colour-box of Clerk Maxwell which may be used for three purposes of physical and physiological interest.

I. As a Spectrophotometer. By means of an appropriate arrangement of prisms, lenses, and slits, two superposed polarised spectra are produced, of which a portion of any desired colour may be observed through an eye-piece. By rotating the Nicol prisms which produce the polarisation, the brightness of these portions of the spectra may be widely varied and thus the intensity of the light which has passed through any given absorbing media may be directly compared.

II. As a means of detecting and estimating colour-blindness The light which yields one of the spectra falls, before passing through the prism, upon a mirror which can be rotated about a vertical axis. By rotating this mirror any one portion of one spectrum can be placed vertically below, and in juxtaposition with any portion of the other spectrum, and hence the colour-perception of an observer can be at once tested if he matches the hues of the strips of the two spectra.

III. Is a means of matching mixed spectral colours with any one colour of a pure spectrum. For this purpose a doubly refracting prism is placed in the path of the light which gives one spectrum. By a proper adjustment of this prism any two colours of this spectrum can be seen as mixed, and by rotating the revolving mirror, any portion of the other spectrum can be compared with the mixed colours until an exact match is obtained. (See an article in Nature, Nov. 17, 1881, by Lord Rayleigh, and in the Journal of Physiology, Vol. v. part 6, by Dr Sheridan Lea.)

The instrument now supplied is an improvement on that shown in Fig. 55.

$£ 15$. 0s. 0d. Barberry.

192. Polariscope, Stand for, as used at the Cavendish Laboratory. It is used for holding any piece of optical apparatus, and for rotating it about the line of vision through angles which can be accurately read to a minute of are by means of verniers. It stands on a heavy tripod foot, and can be adjusted vertically

£10. 0s. 0d. Chokepear.

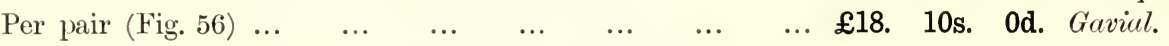

\section{Nicol Polarising Prisms.}

Length of one of

the end edges.

In. $\mathrm{mm}$.

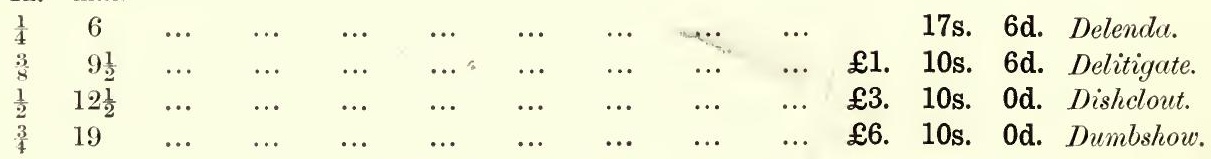




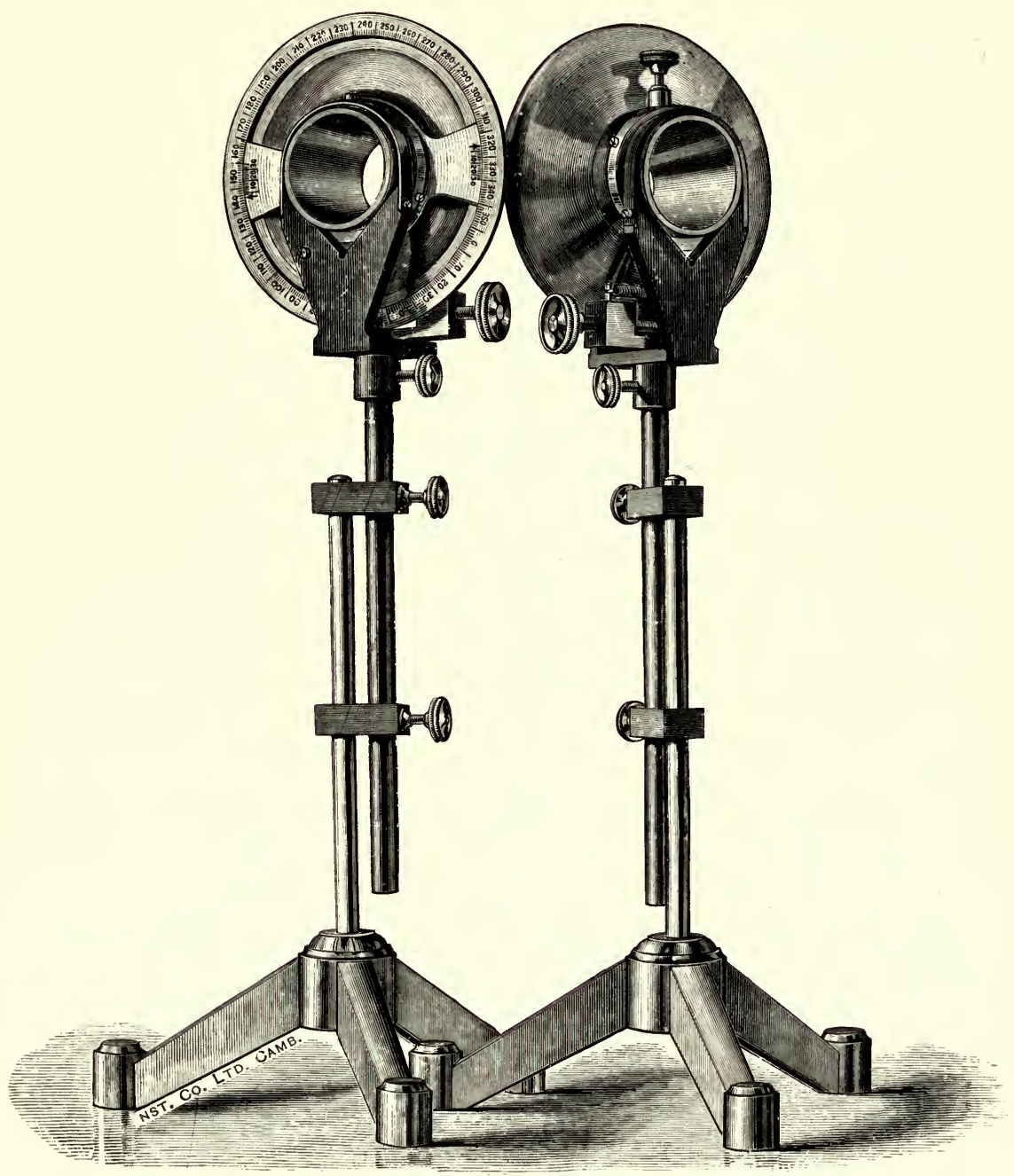

Fig. 56. No. 192.

\section{Student's combined Spectrometer and Spectroscope.}

The divided circle is $126 \mathrm{~mm}$. in diameter divided to half degrees and read by means of a rernier to $1^{\prime}$ of arc. The prism is placed upon a table fitted with an arrangement for setting it vertical. The table rotates and is fitted with tangent screw motion and vernier. The collimator has an adjustable slit and is fitted with a protective cap.

The objectives of both telescope and collimator are $25 \mathrm{~mm}$. clear aperture, the telescope having a magnifying power of 12. The spectroscope is mounted on a strong iron tripod stand 


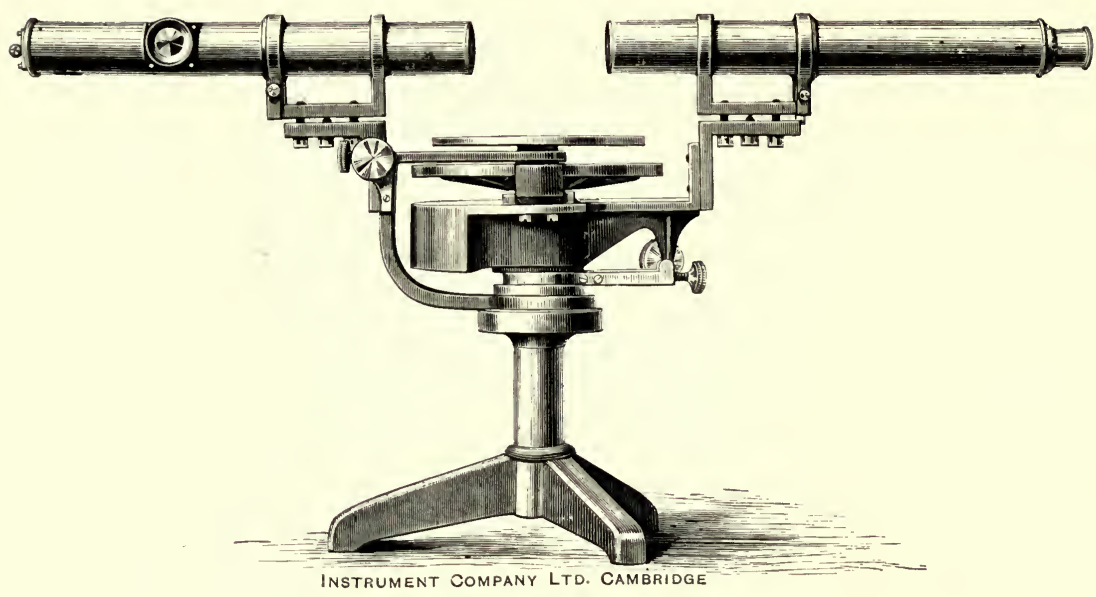

Fig. 57. No. 195 .

195. Laboratory Spectrometer. The circle of $152 \mathrm{~mm}$. diameter is graduated into divisions of $20^{\prime}$ the verniers reading to $20^{\prime \prime}$. It is arranged so that the divisions are in the same plane as those of the verniers attached to the moving parts, thus securing accuracy in reading. The angular movement of the telescope is read by two verniers from the divisions on the outer edge, and the angular movement of the table supporting the prism by two verniers from the inner edge of the divided circle. Readers are provided for reading the verniers.

The telescope and collimator have apertures of about $30 \mathrm{~mm}$. and focal lengths of about $300 \mathrm{~mm}$.

The width of the slit can be accurately adjusted by a fine threaded screw. A levelling table is provided for holding the prism. The cast iron tripod is provided

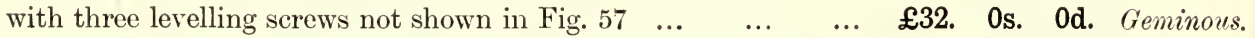

196. Spectroscope Charts. These are useful for mapping absorption spectra and consist of printed charts showing the principal Fraunhofer's lines

$$
\text { per doz. } \quad 3 \text { s. } 6 \text { d. Castlery. }
$$

197. Right Angle Prisms, Best Quality. Optical Crown Glass.

$$
\begin{aligned}
& \text { Length and breadth } \\
& \text { of non-reflecting } \\
& \text { surfaces. }
\end{aligned}
$$

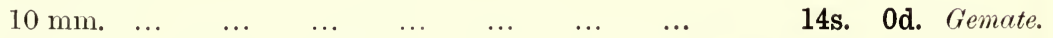

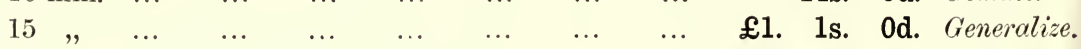

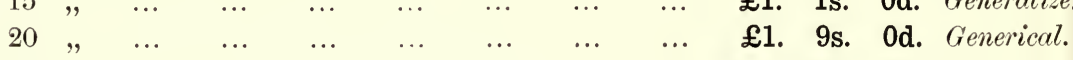

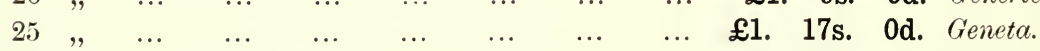

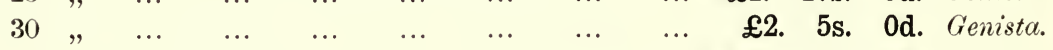

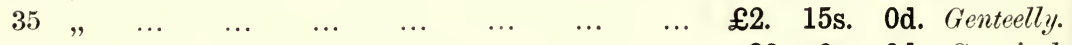

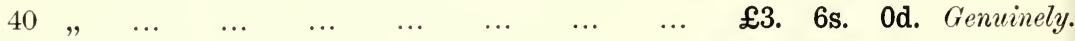

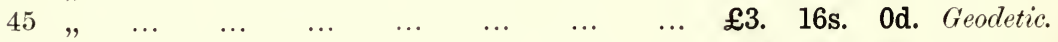

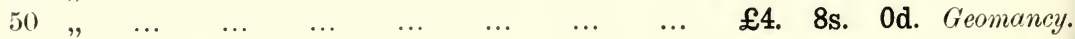

$$
\begin{aligned}
& \begin{array}{llllllllllll}
55 & , & \ldots & \ldots & \ldots & \ldots & \ldots & \ldots & \ldots & £ 5 . & 0 \mathrm{~s} . & 0 \mathrm{~d} . \text { Geoponical. }
\end{array}
\end{aligned}
$$

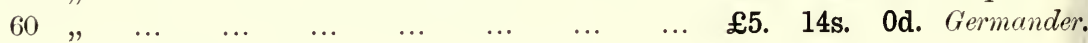




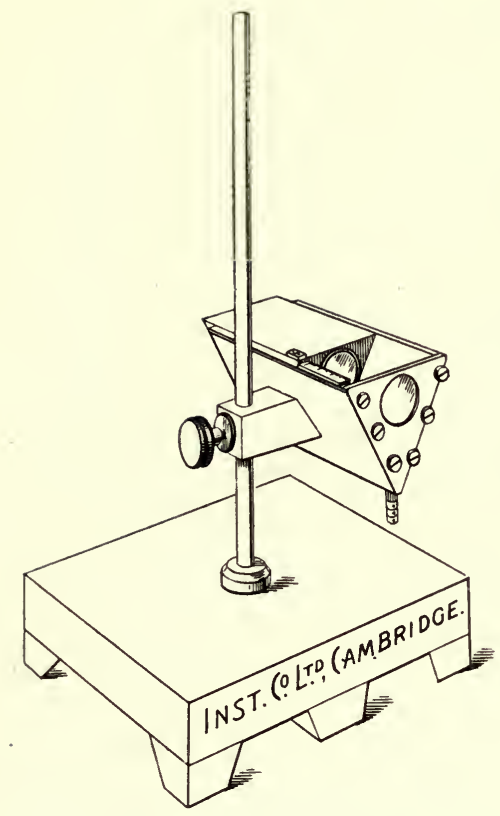

Fig. 58. No. 198.

Special mountings for gratings, large prisms; Spectroscope Slits etc., made to order.

\section{Spectroscope Cell or}

Absorptiometer, for changing the thickness of fluids under observation before the slit of the spectroscope. The instrument is arranged to clamp on one of our Simple Stands (p. 10). The depth of fluid through which the light passes can be varied at pleasure, and made as small as desired; with stand

£3. 18s. 6d. Barbellate.

\section{Hollow Glass Prisms} of $60^{\circ}$ refracting angle or with plane parallel sides, as desired.

Diameter of

Price with Plane cylindrical hole. Parallel glass Plates.
In. $\mathrm{mm}$.
$\begin{array}{lllllll}\frac{1}{2} & 12 \frac{1}{2} & \ldots & \ldots & £ 2 . & 5 \text { s. } & \text { Od. Duunvir. }\end{array}$
$\begin{array}{lllllll}\frac{3}{4} & 19 & \ldots & \ldots & £ 3 . & 10 \text { s. } & \text { Od. Effigies. }\end{array}$
$1 \quad 25 \quad \ldots \quad \ldots \quad £ 4 . \quad 16$ s. Od. Encradling.
$1 \frac{1}{4} \quad 31 \frac{1}{2} \quad \ldots \quad \ldots \quad £ 6.10$ s. 0 d. Excluding.

200. Virtual Images, Convex Half-Lens for experiments on, with needles, etc.

10s. Od. Glabrous

201. Cardinal Points of Lens Systems, Apparatus for the deter-

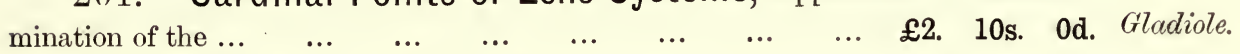

202. Focal Lines formed by Lenses, Apparatus for experiments on

£1. 1s. 0d. Gladwin. 
203. Expansion of a heated metal bar, Apparatus for showing the.

This consists of a stand supporting the metal bar the expansion of which is to be determined, and levers for magnifying this expansion. An index is moved over the face of a vertical scale.

Two rods, one of ordinary steel and the other of non-expansible nickel steel are supplied with the instrument.

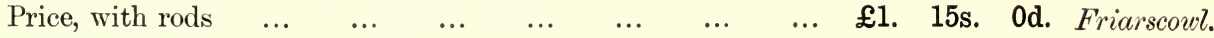

\section{Linear Coefficient of Expansion of a metal bar, Appa-} ratus for determining, by Roy and Ramsden's method.

The bar, the coefficient of expansion of which it is wished to determine, is placed in a copper trough and surrounded by water. Two iron troughs in which are placed standard bars of iron surrounded by ice are arranged parallel to and on either side of the copper trough. The centre bar carries on small vertical supports the object glasses of two telescopes, the eyepieces are carried by one of the iron bars and cross wires by the other iron bar. The bar under examination is mounted on rollers and the amount of its expansion is measured by means of a delicate micrometer screw. See Watson's Text-book of Physics, p. 215 (Fig. 59) $\quad \ldots \quad \ldots \quad \ldots 20.0$.

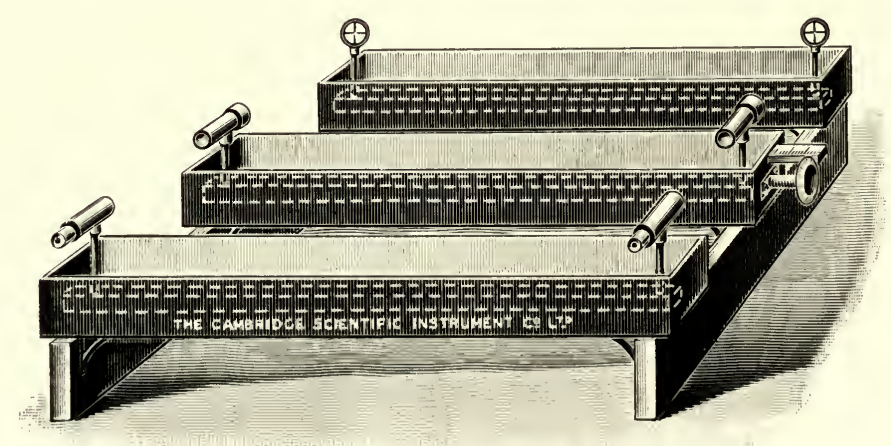

Fig. 59. No. 204. 
205. Steel Gas Regulator, new design (Fig. 60), for maintaining various pieces of apparatus, Incubators, Baths, Sterilisers, etc. at a constant temperature.

The whole of this Regulator is made of steel. The following are some of its advantages over the older types of regulators.

1. It is adjusted with ease to maintain the required temperature.

2. As no glass vessel is used the risk of breakage is reduced to a minimum.

3. Direct metallic connection to the gas supply is readily made, thus aroiding the use of rubber tubing and consequent risk of fire.

Small size without mercury $\quad \ldots \quad \ldots \quad \ldots \quad \ldots 1 . \quad 10$ s. 0 d. Exclaim.

Fig. 60 .

No. 205 .

Large size without mercury

$\begin{array}{lllllll}\ldots & \ldots & \ldots & £ 1 . & 10 \mathrm{~s} . & 0 \mathrm{~d}\end{array}$

0d. Exclamation.

206. Bi-metallic Electric Regulator, consisting of two dissimilar metals in a tube, which on being heated or cooled make or break an electric circuit. The temperature at which this occurs can be regulated by means of a screw

207. Page's Gas Regulator ... $\quad \ldots \quad \ldots \quad \ldots \quad$ _... $\quad$ 6d. Bedagat.

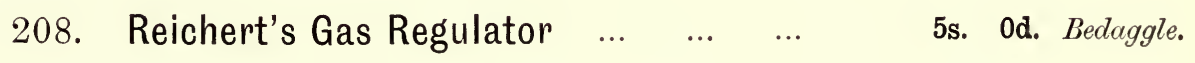

209. Constant Temperature Apparatus. This consists of electric lamps or resistances which are switched in or out of circuit by an electrical control working in connection with a platinum thermometer.

The apparatus can also be arranged to control steam heating coils or gas jets. To order

210. Calorimeter, for use by the method of mixtures. This is similar to that used at the Cavendish Laboratory, and described in Glazebrook

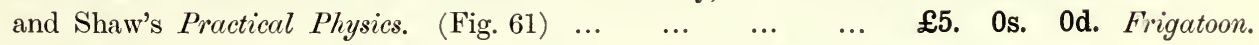

With Shaw's electric heating arrangement instead of steam jacket

£5. 10s. 0d. Frills.

211. Lavoisier's Ice Calorimeter. This consists of three copper vessels placed one inside the other, the substance whose specific heat it is required to determine being placed in the innermost ressel. The two outer ones are packed with ice. The specific heat of the substance can be calculated from the quantity of

£3. 0s. Od. Fringetree. 


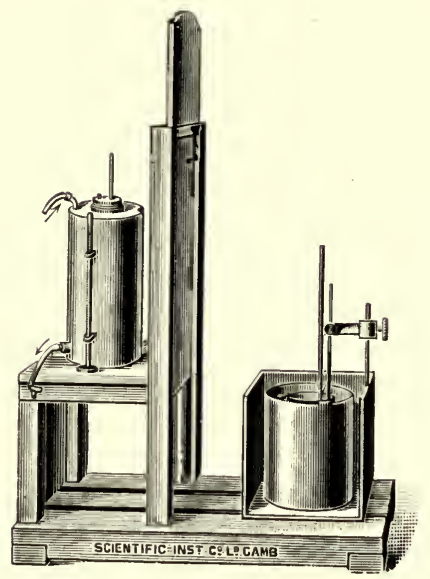

Fig. 61. No. 210.

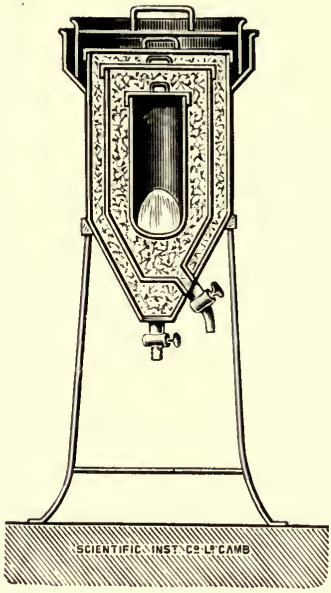

Fig. 62. No. 211.

212. Calorimeter. Dulong and Petit's form for determining the specific heat by the method of cooling. The apparatus consists of a copper vessel placed inside another which is surrounded by a water jacket. The calorimeter is closed by a cork through which a thermometer is passed ...

£1. 15s. 0d. Frippery.

213. Rosenhain's Coal Calorimeter, for determining the calorific value of coal. It consists of a glass vessel surrounded by water, which is placed in a polished brass ressel enclosed in a wooden box to prevent radiation. The coal is

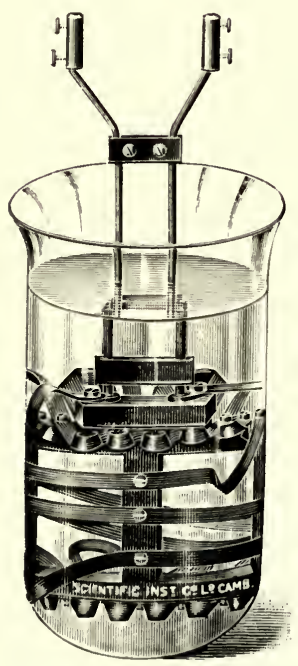

Fig. 63. No. 214. placed inside a crucible in the inner vessel, oxygen is admitted, and fired electrically. The heat produced by the combustion is communicated to the water in the outer vessel, whose temperature is indicated by a delicate thermometer. The calorific value of the coal can be determinet from the mass of water, rise in temperature, \&c. The glass vessel consists of a lamp chimney in order that the renewals may be as inexpensive as possible $\quad \ldots \quad £ 7 . \quad 10$ s. 0 d.

Cheap form $\quad \ldots \quad \ldots \quad \ldots \quad \ldots \quad \ldots \quad £ 5.10$ s. 0 d.

For accessories see Special Pamphlet describing this instrument.

\section{Heat equivalent of Electric Energy.} Apparatus for measuring. It consists of a glass vessel in which is placed a resistance formed of a broad strip of manganin. The resistance is immersed in water whose temperature is indicated by a thermometer. An electric current heats the manganin strip, and from the rise in temperature of the water the heat equivalent of the electric energy expended can be determined (Fig. 63)

£3. $15 \mathrm{~s}$. 0d. Frockcoat: 


\section{Mechanical equivalent of Heat. Apparatus for deter-} mining the. A vertical spindle suitably mounted can be rotated by means of

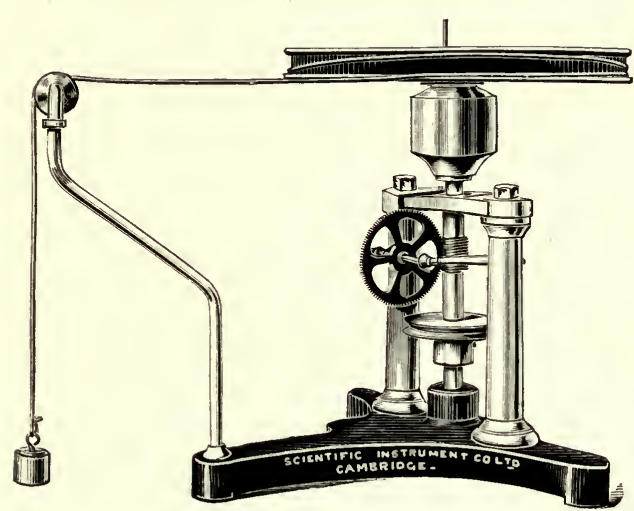

Fig. 64. No. 215. a driving pulley. A brass cup lined with cork is fixed to the top of the spindle. A thin brass vessel in the shape of a hollow truncated cone fits tightly into the hollow in the cork and within this again another brass vessel of a similar shape fits. This last vessel is provided with two pins which fit into a horizontal wooden wheel, so that when the wheel is turned the vessel is turned also. A string wound round the edge of the wooden wheel, passes over a smooth pulley, and supports a weight of about 250 grammes. When the bottorn cup and spindle are rotated the friction between the two cups is sufficient to keep the weight supported, in addition to producing heat which is communicated to a known quantity of water placed inside the inner cup. A counter shows the number of revolutions made by the spindle and bottom cup, and a thermometer inserted in the water gives the corresponding rise of temperature. From these data the mechanical equivalent of heat can be determined.

The instrument now supplied is modified in several details to that shown in

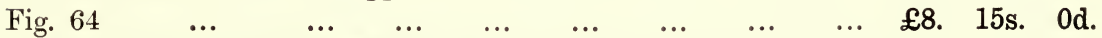

See Griffiths' Thermal Measurement of Energy, p. 125, and Glazebrook and Shaw's Practical Physics.

\section{Callendar and Griffiths' Patent Platinum Thermometer.}

This instrument consists of a coil of fine platinum wire wound on a mica frame and inserted in a glass or porcelain tube. The increase of the resistance of this platinum coil with rise of temperature is a measure of that temperature. By making the coil form part of a Wheatstone Bridge any change in resistance, and consequently of temperature, can be measured with great accuracy.

Owing to an arrangement of compensating leads, no error is introduced by the variation of the temperature of the wires connecting the thermometer with the indicator or recorder. The thermometer can thus be placed in positions where it would be impossible to read or use a mercury thermometer. At the same time a series of thermometers distributed over a considerable area can be read from one central station by means of an indicator and switchboard. Temperatures as high as $1200^{\circ}$ C. can be measured without difficulty, and consequently these thermometers are specially suitable for indicating the temperatures of furnaces, superheaters, etc.

When used in conjunction with Callendar's Electric Recorder a continuous record of temperatures may be obtained. 
For further information regarding the prices of Callendar Recorders, thermometers especially suitable for commercial work, temperature indicators and accessories, see special list which will be sent post free on application.

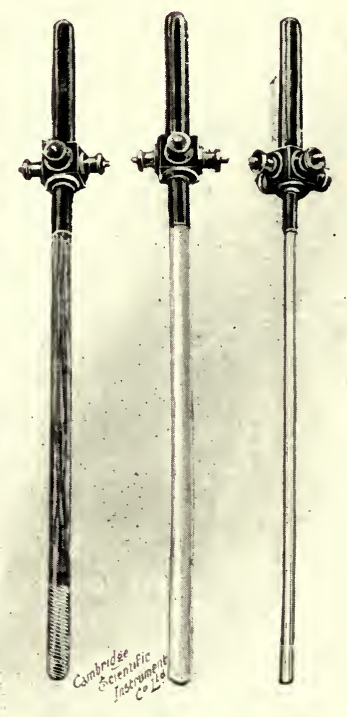

Fig. 65. Nos. 216-223.

\section{Thermometers especially suitable for use in Laboratories.} Fig. 65.

216. Glass Tube $33 \mathrm{~cm}$. long, $9 \mathrm{~mm}$. in diameter with copper leads, resistance in ice approximately $2 \cdot 6 \mathrm{ohms}$, F.I. $1 \mathrm{ohm}$, suitable for temperatures of $300^{\circ} \mathrm{C}$.

£2. 12s. 6d. Effodient.

217. Glass Tube $33 \mathrm{~cm}$. long, $9 \mathrm{~mm}$. in diameter with copper leads, resistance in ice approximately $5 \mathrm{ohms}$, F.I. $1.8 \mathrm{ohms}$. Suitable for temperatures of $500^{\circ} \mathrm{F}$.

£2. 12s. 6d. Effulging.

218. Porcelain Tube, $33 \mathrm{~cm}$. long, $14 \mathrm{~mm}$. in diameter, resistance in ice approximately $2 \cdot 6 \mathrm{ohms}$, F.I. $1 \mathrm{ohm}$, for temperatures up to $700^{\circ} \mathrm{C}$. £3. 0s. 0d. Electively.

219. Porcelain Tube, $33 \mathrm{~cm}$. long, $14 \mathrm{~mm}$. in diameter, resistance in ice approximately $5 \mathrm{chms}$, F.I. $1.8 \mathrm{ohms}$, for temperatures up to $1300^{\circ} \mathrm{F} . \quad £ 3 . \quad 0$ s. 0d. Electuary.

220. Porcelain Tube, $33 \mathrm{~cm}$. long, $14 \mathrm{~mm}$. in diameter, resistance in ice approximately $2.6 \mathrm{ohms}$, F.I. $1 \mathrm{ohm}$, for measuring temperatures up to $1200^{\circ} \mathrm{C}$.

£5. 5 s. 0d. Elegiac. 
221. Porcelain Tube, $33 \mathrm{~cm}$. long, $14 \mathrm{~mm}$. in diameter, resistance in ice approximately $5 \mathrm{ohms}$, F.I. $1.8 \mathrm{ohms}$, for temperatiures up to $2200^{\circ} \mathrm{F}$.

£5. 5s. 0d. Elegiast.

222. Porcelain Tube, $40 \mathrm{~cm}$. long, $12 \mathrm{~mm}$. in diarneter, resistance in icc approximately $2 \cdot 6 \mathrm{ohms}$, F.I. $1 \mathrm{ohm}$, with plàtinum leads throughout

£5. 10s. 0d. Elevator.

This pattern has been employed by Messrs. Heycock and Neville in their investigations on the melting point of metals.

223. Porcelain Tube, $30 \mathrm{~cm}$. long, $7 \mathrm{~mm}$. in diameter, resistance in ics approximately $2.6 \mathrm{ohms}$, F.I. $1 \mathrm{ohm}$. Specially designed for measuring the tempera-

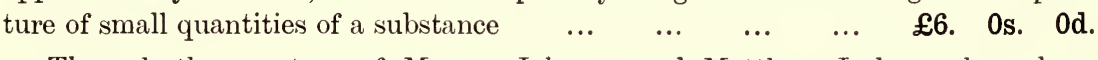

Through the courtesy of Messrs. Johnson and Matthey, Ltd., we have been enabled to lay in a large stock of especially pure platinum wire. This is from the same melting as the platinum wire supplied to the British Association and selected by them for the manufacture of Standard Platinum Thermometers. If desired the resistance coil of any of the above thermometers will be made of this wire at an extra charge of $7 \mathbf{s} .6 \mathbf{d}$.

The above Thermometers can be fitted with 2 yards of flexible leads and tangs without terminals on the thermometer head, thus avoiding the risk of thermal effects at the thermometer head, at an additional cost of $5 \mathrm{~s}$.

Small copper cups can also be fitted in place of terminals on the heads of the thermometers. Leads can then be attached by means of a fusible alloy placed in the cups. Extra, including sufficient alloy, 10s.

For the accurate measurement of temperature by means of platinum thermometers the resistance boxes shown on pp. $84-87$ must be employed. A special catalogue devoted to platinum thermometers will be sent post free on application.

\section{Callendar and Griffiths' Patent Temperature Indicator.}

This instrument may be used in conjunction with any of the above thermometers where an accuracy of not more than $0.5 \%$ is required.

It consists of a portable Galvanometer combined with a Wheatstone Bridge, and so arranged that by turning a couple of milled heads at the top of the Indicator the temperature of the thermometer may be read in degrees Centigrade or Fahrenheit.

The electrical resistance of the coil of wire constituting the thermometer changes proportionally with its temperature. The resistance of this coil is balanced against the fixed resistances in the instrument, the galvanometer showing when a balance has been obtained by the pointer remaining at rest opposite the index mark.

In the Centigrade Indicator ten resistance coils each of $1 \mathrm{ohm}$ are arranged in series with a bridge wire also having an equivalent resistance of $1 \mathrm{ohm}$ and the thermometer is adjusted so that a change in temperature of $100^{\circ} \mathrm{C}$. causes a change in its resistance of $1 \mathrm{ohm}$. The small ebonite milled head at the top of the instrument moves a travelling contact round the bridge wire, while another milled 
head just beneath the first moves a switch over a series of studs connected to the coils previously mentioned. A divided scale is carried round by the travelling contact which shows in degrees Centigrade the amount of resistance in use on the bridge wire. This added to that indicated by the pointer attached to the switch gives the temperature of the thermometer.

The Fahrenheit Indicator is similarly arranged but the thermometer is adjusted so that a change in its temperature of $180^{\circ}$ Fahrenheit makes a change in its resistance of $0.9 \mathrm{ohms}$.

The readings of the temperatures obtained with this instrument are on the Platinum Scale. It is sometimes convenient to know what the readings would have been if an air thermometer had been used instead. A table of corrections is supplied with every thermometer by means of which these values can be obtained.

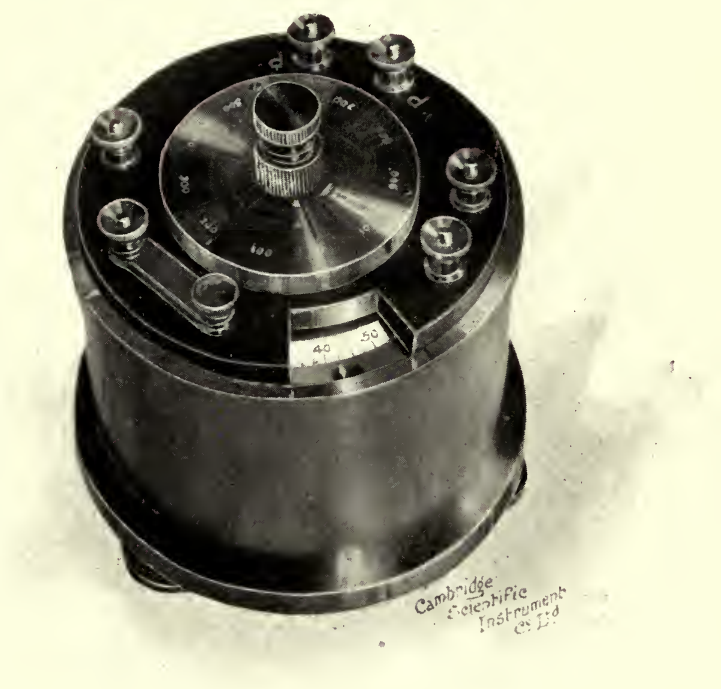

Fig. 66. No. 224-228.

Instruments with the following ranges are not infrequently in stock but special ranges will be made to order:

224. $0^{\circ}$ to $100^{\circ} \mathrm{F}$. or C. (especially suitable for Meteorological work).

$£ 20$. 0s. Od. Endecagon.

225. $\quad 0^{\circ}$ to $200^{\circ}$ F. or C. $\quad \ldots \quad \ldots \quad \ldots \quad \ldots \quad \ldots \quad \ldots \quad \ldots 20.0$ 0s. 0 d. Endocarp.

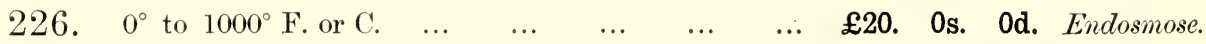

227. $\quad 0^{\circ}$ to $2200^{\circ}$ Fahr. $\quad \ldots \quad \ldots \quad \ldots . \quad \ldots \quad \ldots \quad \ldots 20.0$ 0s. 0d. Engendrar.

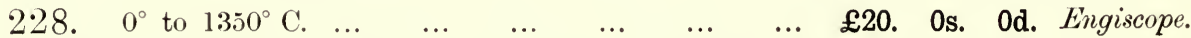

Full instructions are sent with the instrument. Unless ordered to the contrary an instrument reading in degrees Centigrade will be supplied. 
229. The Indicator can be supplied in a travelling case with battery complete

Price complete £22. 0s. Od. Englad.

230. For marine work it is mounted in gimbals with a specially designed $\begin{array}{llllllllllll}\text { galvanometer } & \ldots & \ldots & \ldots & \ldots & \ldots & \ldots & \ldots & \ldots & £ 35 . & 0 \text { s. } & 0 d . \text { Engraft. }\end{array}$

This form of mounting was adopted in the Instrument supplied to the Naval Boilers Committee of the Admiralty.

\section{Whipple's Patent Gas Scale Temperature Indicator.}

This instrument has been designed to avoid the trouble and risk of error in converting temperatures obtained with a platinum thermometer into temperatures on the gas scale. Temperature measurements are almost universally given on the latter scale. With this instrument no table of corrections is required as the temperatures are given directly on the gas scale. Temperatures which are changing rapidly can also be followed more closely than with the Indicators mentioned above.

The instrument is extremely portable and is fitted in case with batteries complete.

$\begin{array}{llllllllllll}231 . & 0^{\circ} \text { to } 2000^{\circ} \mathrm{F} . & \ldots & \ldots & \ldots & \ldots & \ldots & \ldots & £ 20 . & \text { 0s. } & \text { 0d. Excoriated. } \\ 232 . & 0^{\circ} \text { to } 1400^{\circ} \text { C. } & \ldots & \ldots & \ldots & \ldots & \ldots & \ldots & £ 20 . & \text { 0s. } & \text { 0d. Foundry. }\end{array}$

233. Pyrometer (Thermo-Electric Pattern) for measuring temperatures from $0^{\circ}$ to $1600^{\circ} \mathrm{C}$; ; adapted for smelting, distilling, foundry work, etc., consisting of an accurate milli-voltmeter and a platinum-iridium thermo-electric couple $33 \mathrm{~cm}$. long enclosed in a porcelain tube ... $\quad \ldots \quad$ Complete $£ 12 . \quad 10$ s. Od. Frogfish.

The indicator is a voltmeter of the d'Arsonval type, the temperature readings being shown directly on a scale.

Owing to the high internal resistance of the instrument it may be set up at a considerable distance from a furnace without the necessity of making allowance for the resistance of the leads or the temperature of the voltmeter.

234. Thermo-Couples. These are constructed of platinum, platinumrhodium, the couple being fused together and protected in a double porcelain tube $33 \mathrm{cms}$. long, $14 \mathrm{~mm}$. diameter, with head and terminals ... $\quad \ldots \quad £ 1 . \quad 10 \mathrm{~s} .6$ 6. Enable.

Do. Do. with handle fitted with reels of wire to replace the thermo-junction if damaged. See Mesure des Temperatures Elévées, H. Le Chatelier,

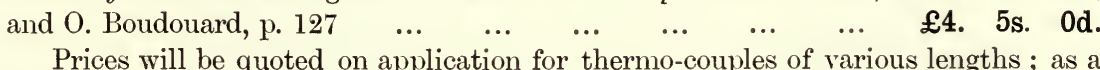
rough rule the cost is about $\mathbf{7 s}$. $6 \mathrm{~d}$. per linear foot exclusive of tube and head.

All the above prices are subject to the variations in the market price of platinum and rhodium.

235. Jena Glass Thermometers. Divided on stem to degrees reading $0^{\circ}$ to $100^{\circ} \mathrm{C}$. Specially made for the Instrument $\mathrm{Co}$.

each

3s. 0d. Chromium.

$\begin{array}{lllllll}\text { Divided to half. degrees } & \ldots & \ldots & \ldots & \ldots & \ldots & \text { each }\end{array}$

4s. 6d. Chronicled. 
236. Calibration of mercury thermometers. The apparatus consists of two micrometer microscopes suitably mounted and sliding along a horizontal scale. The length of the thread of mercury in the thermometer may be read over the whole length of the thermometer. (See Guillaume's Thermometrie de Precision.)

237. Thermo-Pile. Of 56 couples, mounted on brass pillar and base. The pile cell is hinged and can be raised or lowered, with two cones in case

£4. 4s. 0d. Fiontless.

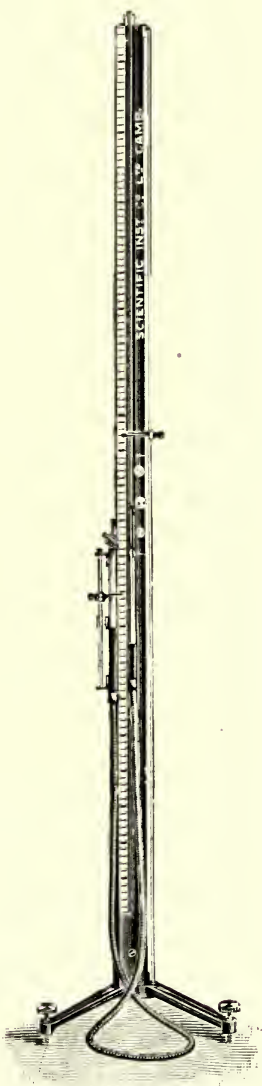

Fig $67 . \quad$ No. 238 .

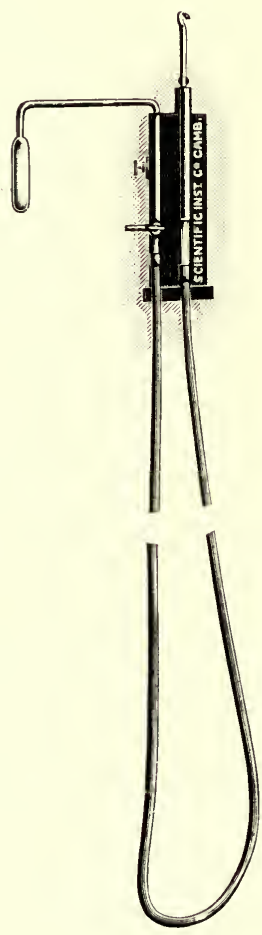

Fig. 68. No. 238.

238. Boyle's Law Apparatus. Large pattern (Fig. 67), with glass vessel and accessories (Fig. 68) enabling the apparatus to be used as an air-thermometer . 


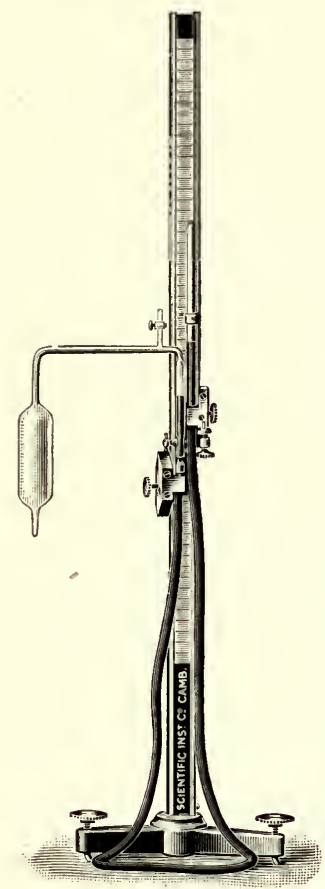

Fig. 69. No. 242.
239. Boyle's Law Apparatus (Cheap form $) \quad \ldots \quad \ldots \quad \ldots \quad \ldots \quad \ldots \quad £ 1 . \quad 10$ s. 0 d. Froth.

240. Standard Gas Thermometer; very similar to that used at the National Physical Laboratory. Described in Watson's Physics, p. $230 £ 70 . \quad$ 0s. Od. Frozenness.

Porcelain and Jena glass tubes for use with the above, to order.

\section{Constant Volume Air Ther-} $\begin{array}{lllllllll}\text { mometer } & \ldots & \ldots & \ldots & \ldots & £ 2 . & \text { 0s. } & \text { Od. Fruitful. }\end{array}$

242. Jolly's Air Thermometer, with scale of mirror glass (Fig. 69) $\quad \ldots \quad £ 10$. 0s. 0d. Fuchsia.

\section{Expansion of gases at constant} pressure. This apparatus consists of a bulb for containing the gas experimented on, a mercury manometer with graduated tube surrounded by a jacket, connecting tubes and the necessary stopcocks, the whole being fixed on a stand with levelling screws. A hypsometer is also provided for heating the gas, the apparatus can be supplied without this if desired.

With hypsometer complete (Fig. 70) £10. 0s. 0d. 'Fucoidal. Without hypsometer $\quad \ldots \quad \ldots \quad £ 7$. 10s. 0 d. Fugue.

244. Coefficient of expansion of Mercury, Apparatus for determining. This is a modified form of Dulong and Petit's apparatus. It consists of two long vertical glass tubes connected together by a cross tube. The vertical tubes are surrounded by iron cylinders which can be filled with ice or steam. The whole arrangement is mounted on a substantial base board. Special arrangements are adopted for making the measurements of the heights of the mercury columns convenient and accurate

$£ 14.0$ s. 0d. Fulmineous.

245. Hypsometer. Regnault's form made of copper, with gas burner

£2. 10s. 0d. Ethnic.

246. Hypsometer. Special form designed by Dr Guillaume for ascertaining the boiling point with great accuracy. The thermometer may be placed in both vertical and horizontal positions. Complete with reading microscope, manometer and condenser (Fig. 71). (See Thermométrie de Précision by Guillaume, and

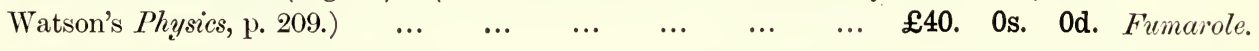

246 a. Ice Vessel, Regnault's form made of copper, for determining freezing points ...

£1. 0s. 0d. Etiology. 


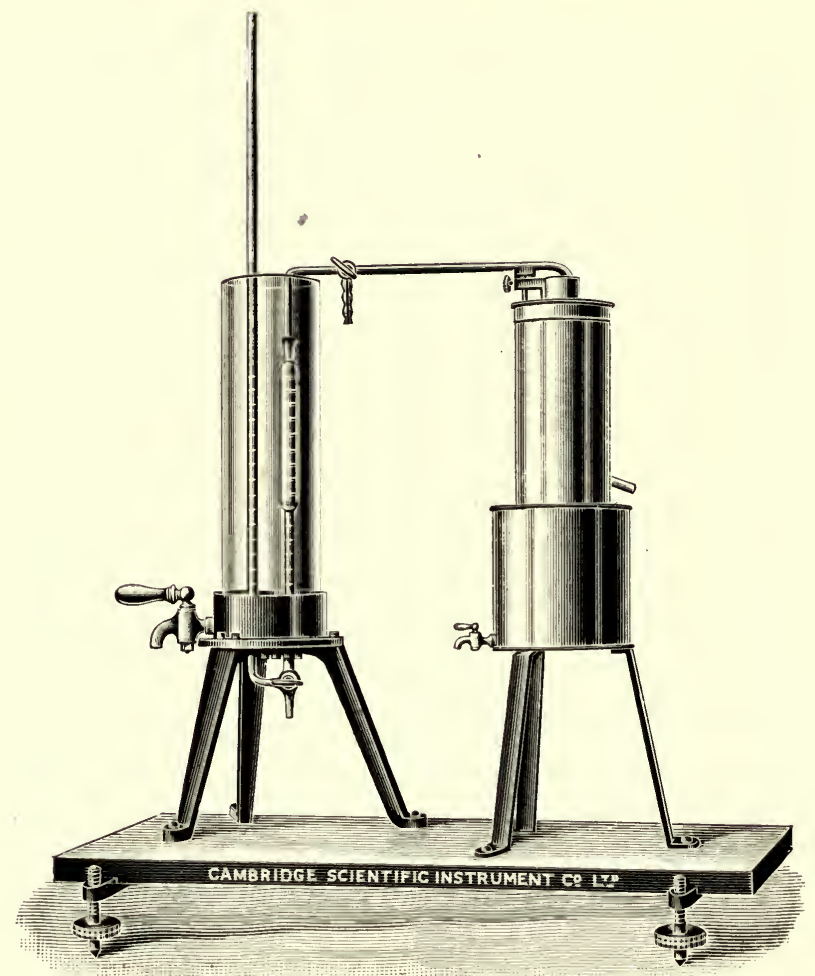

Fig. 70. No. 243.

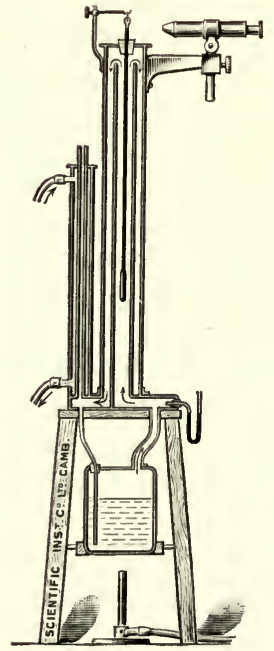

Fig. 71. No. 246.

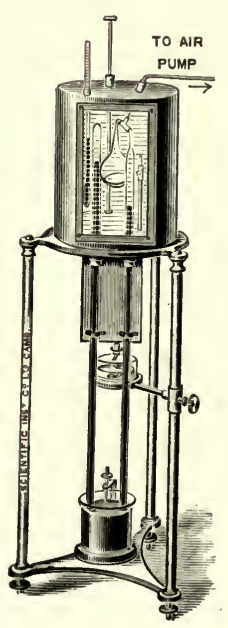

Fig. 72. No. 247. 


$$
\text { Cambridge, England. }
$$

247. The Saturation Pressure of Vapours, Regnault's Apparatus for determining, from $0^{\circ} \mathrm{C}$. to $50^{\circ} \mathrm{C}$. Two glass tubes dip into the same glass vessel, their upper parts being surrounded by a metal box into which a plate-glass window is fitted (Fig. 72). (See Deschanel's Natural Philosophy.) $£ 10.0$ os. 0 d.

248. Vapour densities, Apparatus for determining, by Dumas' Method. Outer metal vessel, bulb tube. thermometer, stirrer, and supports ...

£1. 10s. 0d. Fumigation

249. Do. do. by Victor Meyer's Method. Inner glass tube with branch

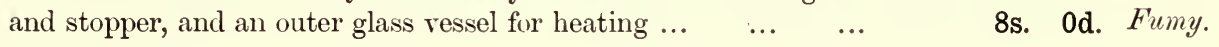

250. Hope's Apparatus for determining the temperature at which water has its maximum density. This consists of a glass cylinder with a jacket surrounding the middle part of it. Tubulures are provided in order that thermo-

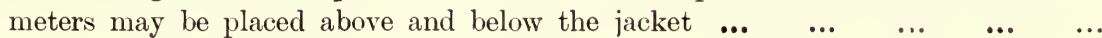
Price without thermometers £1. 0s. 0d. Functiona.

251. Wet and Dry Bulb Hygrometer. Mason's standard form, consisting of two mercury thermometers on a stand, and divided on stem, the bulb of one being kept moist by means of a cotton wick, one end of which dips into a

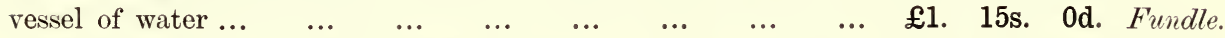

Wet and Dry Bulb Hygrometers are also made with platinum thermometers used in conjunction with a Callendar Recorder. This arrangement is in use at the Khedival Observatory at Cairo.

For prices see special List of Platinum thermometers, \&c.

\section{Daniell's Hygrometer ... $\quad \ldots \quad \ldots \quad \ldots \quad £ 1$. 10s. 0d. Fungiform.}

\section{Dines' Hygrometer $\quad \ldots \quad \ldots \quad \ldots \quad \ldots \quad$ 22. 10 s. 0 d. Fungous.}

254. Melloni's Apparatus for studying the reflection, refraction, absorption, and polarization of radiant heat. The bed of this apparatus is made of cast iron $120 \mathrm{cms}$. in length, and is very rigid. It is carried on four levelling screws, and the supporting surfaces for the carriers are $\mathrm{V}$ and a plane respectively. Three hemispheres are fixed underneath each of the four pillar blocks, thus ensuring geometrical contact. The accessories supplied comprise a Locatelli lamp, thermopile, cube with radiating surfaces of four different substances, thermometer, single, double, and revolving screens.

A radial arm is supported by one of the pillars fixed to the bed, and this arm also carries three sliding pillars, and is fitted with a divided circle $\ldots \ldots \ldots \ldots$

£60. 0s. 0d. Funicle. 


\section{Accessories for use with above Melloni Apparatus:}

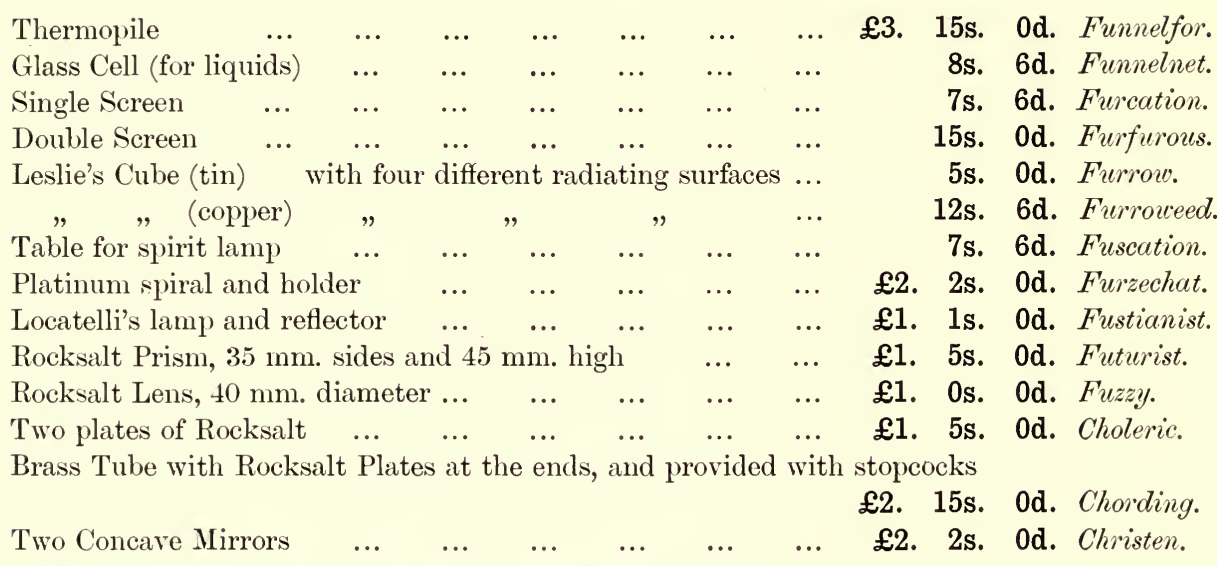

256. Boys' Radio-Micrometer. The radiation is received on a piece of blackened copper foil $4 \times 2 \mathrm{~mm}$. to the upper edge of which two exceedingly fine bars of strongly thermo-electric alloy are soldered. The other ends of the bars are connected by a fine copper or silver wire stirrup, thus forming a complete electrical circuit. This circuit is hung in a magnetic field produced by permanent magnets, and the deflection, which is produced when the junction is heated, is measured by a mirror and a spot of light in the usual manner. The mirror and circuit are made very light and have an extreinely small moment of inertia, and are suspended by a delicate quartz fibre.

The instrument is far more delicate than a thermopile and galvanometer ; it is dead-beat in its action, the spot of light moves up to a definite point on the scale and comes to rest without oscillation: its indications are proportional to the radiation received: it is not affected by the magnetism of objects near it: it is very insensitive to changes of temperature other than in its very limited cone of vision, as the circuit is suspended in a narrow hole in a mass of metal. An armature is provided, by means of which the strength of the magnetic field, and hence the sensibility of the instrument, can be reduced by sliding it nearer the pole pieces, or the pole pieces themselves may be altered in position so that the sensibility or logarithmic decrement may be changed at will. They may be placed with either their narrow or their broad ends facing one another according to circumstances.

Complete instructions and certificate are sent with the instrument.

See "Preliminary note on the 'Radio-Micrometer,' a new instrument for measuring the most feeble radiation." By C. V. Boys, Proc. Roy. Soc. Vol. 42, p. 189. Also see Nature, April 7, 1887, p. 549. Also see Proc. Roy. Soc. Vol. 44, p. 96 . Also Phil. Trans. Vol. 180, 1889, p. 159, and Cantor Lectures, Soc. Arts, 1889.
Price with one Suspension ...
-.. $\quad \cdots \quad \ldots$
1.. £17. 10s. 0d. Chrysalid.
Extra Suspensions ... $\quad \ldots$
£2. 10s. 0d. Churchwork.

For lampstands and scales see p. 77 . 


\section{Conductivities of Gases, Apparatus for Comparing.}

This consists of two vertical glass tubes $125 \mathrm{~mm}$. long and $5 \mathrm{~mm}$. diameter, having platinum wires of equal length and resistance fixed inside them. One of the tubes is filled with hydrogen and sealed up, the other is provided with two stopcocks so that any gas can be admitted for comparison with hydrogen.

The same electric current is passed through both the platinum wires. The wire in the tube containing hydrogen only glows faintly owing to the conduction of the heat by the gas ; the amount of incandescence in the other wire depends upon the gas under examination.

The apparatus is mounted on a stand provided with terminals $£ 3.10$ s. 0d. Churnstaff.

\section{Freezing Point of Solutions, Beckmann's Apparatus}

for determining. This consists of a glass tube containing a delicate thermometer and a stirrer; this tube is placed inside a wider tube which serves as an air jacket. The whole is enclosed in a larger outer vessel in which a freezing mixture can be placed. See Glazebrook and Shaw's Practical Physics.

£2. 5s. 0d. Cicatrized.

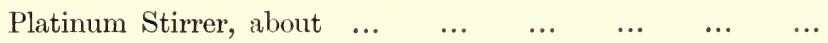

15s. 0d. Autograph. 


\section{MAGNETISM.}

259. Magnetometer. Unifilar, Kew pattern, for observations of deflection, vibration, and declination. The instrument is provided with collimator magnet, deflection magnet with mirror, inertia bar, thermometers, vibration box, deflection bar, plummet, etc. The magnets are of the dimensions approved by the National Physical Laboratory. The telescope is fitted with irory scale as suggested by Professor Rücker. Packed in mahogany travelling case with the exception of the deflection bar and tripod which are packed in a separate case $\quad \ldots \quad \& 70 . \quad$ Os. $\quad$ Od.

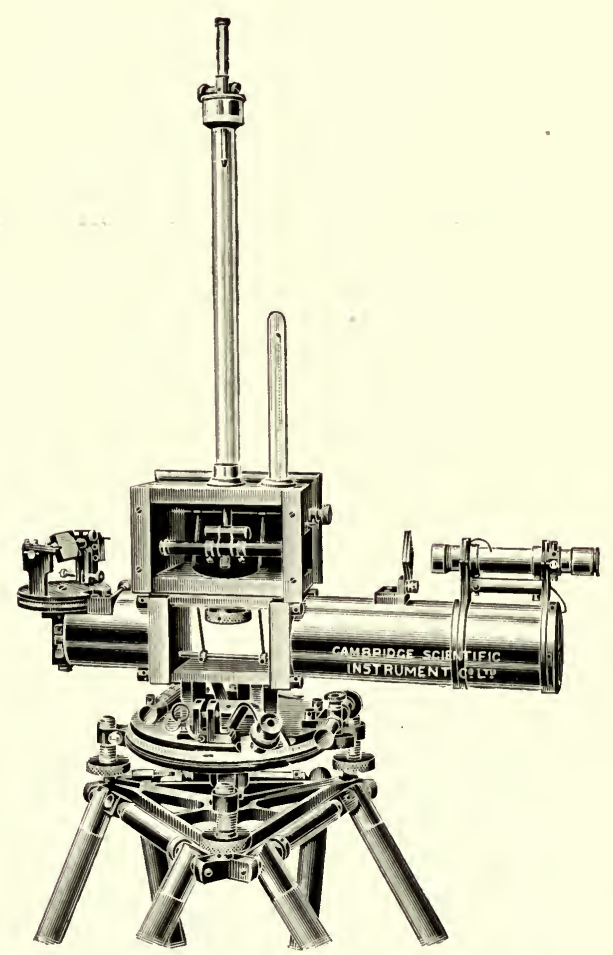

Fig. 73. No. 259.

260. Students' Magnetometer. This consists of a circular brass box supported on three levelling screws and containing a circular scale whose centre coincides with the centre of the bottom of the box. Two boxwood scales, each about $40 \mathrm{cms}$. long and divided to mms. are attached to the box. The carriers for the external magnets are provided with spring clips to keep them firmly in any desired 
positions on the scale, and also with a pointer for reading their positions. The tube carrying the suspension is fastened directly to the glass top of the magnetometer box proper and the entire upper part can be removed by unscrewing two set screws. The magnets are cylindrical in shape and are supported in a brass stirrup, an aluminium pointer being fixed below, just over the scale. The suspension can easily be replaced if damaged. A mirror is also provided so that the instrument can be used with a reading telescope and scale if desired $\quad \ldots \quad £ 5 . \quad 0$ s. 0 d.

261. Magnetographs, as designed by Professor W. Watson, F.R.S.

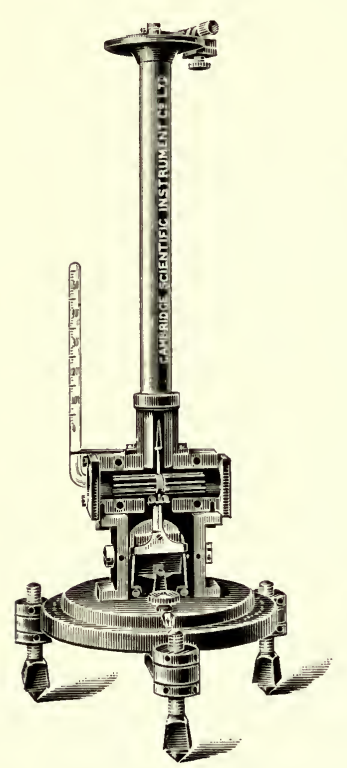

Fig. 74. No. 261. The magnets of these instruments, in the case of the Horizontal Force and Declination, each consist of a group of magnetised steel wires $50 \mathrm{~mm}$. long and $1.5 \mathrm{~mm}$. in diameter, supported in an aluminium mounting which also carries a mirror. (The vertical force magnets are $100 \mathrm{~mm}$. long.) The horizontal force magnet is suspended by means of a quartz fibre whose suspension is provided with a graduated head and screw motion. The construction of this instrument is shown in Fig. 74 . The drums carrying the photographic paper are placed in boxes which can be closed, in order that they may be removed to the dark room, thus avoiding the necessity for darkening the room in which the instruments are placed. The drums are rotated by clockwork. By moving the slit, two days' record can be taken on the one sheet of paper.

Instruments of this type are being used in the Indian Magnetic Survey. See Terrestrial Magnetism, W. Watson, Vol. vi., p. 187.

For recording horizontal force and declination. Complete $\quad \ldots \quad \ldots \quad \ldots \quad \ldots \quad \ldots \quad \ldots \quad £ 150.0$ 0s. 0 d. Cinque.

For recording horizontal and vertical forces and declination. Complete $\ldots . \quad \ldots \quad \ldots . \quad £ 230$. 0s. 0d. Cithara.

\section{Horizontal Force Magnetograph, with instrument similar} to that shown in Fig. 74, with recording drum and clockwork complete

£87. 10s. Od. Aversevely.

263. Declination Magnetograph, with instrument similar to that shown in Fig. 74, with the exception that there is no thermometer, with recording drum and clockwork complete

£87. 0s. 0d. Averted.

264. Vertical Force Magnetograph, with recording drum and

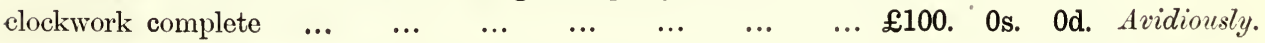

Quartz Fibres for suspending magnets, see p. 75.

265. Dip Circle. Kew pattern, on brass tripod with levelling screws. The instrument is capable of slow motion round a vertical axis, the vernier reading 
to minutes. The needle is enclosed in a glass air-tight case, and when in use its pivots rest on agate knife edges. Reading microscopes are provided for reading the inclination.

The vertical circle reads by verniers to $30^{\prime \prime}$ of are. The horizontal axis carries microscopes, two verniers and fine adjustment arrangement.

Two bar magnets and apparatus to hold magnet for magnetising are supplied.

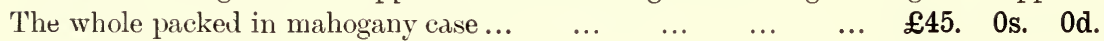

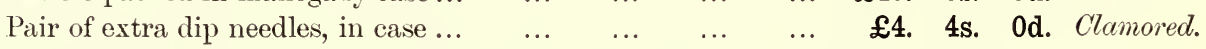

If provided with coil for reversing the magnetism by means of an electric

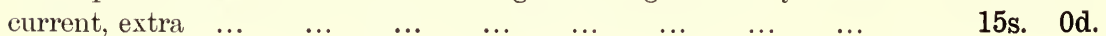

266. Dip Circle. This is contained in a circular brass case with glass front and back. It is mounted on a circular base provided with levelling screws, and with a slow motion round the vertical axis. The needle is $10 \mathrm{cms}$. long and delicately pivotted in agate centres. Silvered circles divided to degrees

£8. 10s. 0d. Claptrap.

\section{Distribution of Magnetism in a Steel Bar, Apparatus}

for Measuring the. This is similar to that described in Ayrton's Practical Electricity, 1900 edition, p. 64.

Mahogany base board, graduated scale, dial, and pointer complete £3. 0s. 0d. Clasplock.

268. Do. do. Rowland's Method, with long soft iron'bar, magnetising bobbin, induction coil and supports. See Stewart and Gee's Practical Physics, Vol. II.

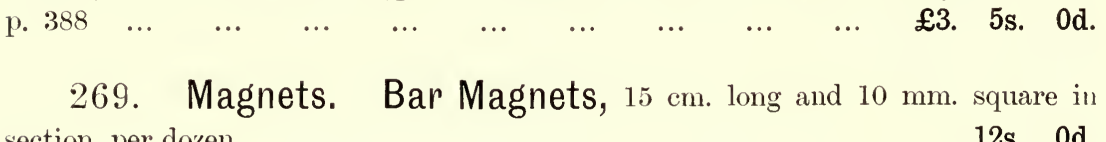

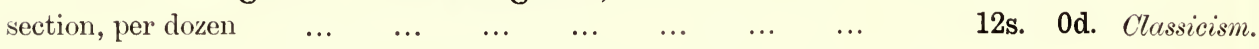

270. Pair of Bar Magnets, $330 \times 25 \times 6 \mathrm{~mm}$., in box with keepers $\ldots$

£1. 0s. 0d. Claudicant.

271. Ball-ended Magnets for demonstrating the positions of the

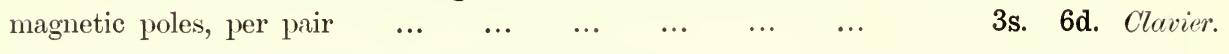

272. Suspended Magnet for plotting magnetic fields, or for use as a magnetometer. The magnet with aluminium pointer is suspended by means of a silk fibre from a brass stand. Complete $\quad \ldots \quad \ldots \quad \ldots$

6s. 6d. Claystate.

273. Delezenne Circle, for showing the inductive effect of the earth's magnetism. Provided with brass divided circle, and clamp for fixing the coil at any

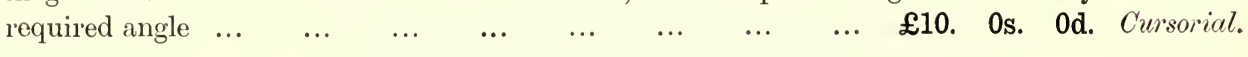




\section{ELECTRICITY.}

274. Insulating Stands. Maxwell's design. See Elementary Treatise on Electricity, by J. Clerk Maxwell, p. 14 ... $\quad \ldots \quad \ldots \quad \ldots \quad \ldots 1 . \quad 10$ s. $0 d$. Admirer.

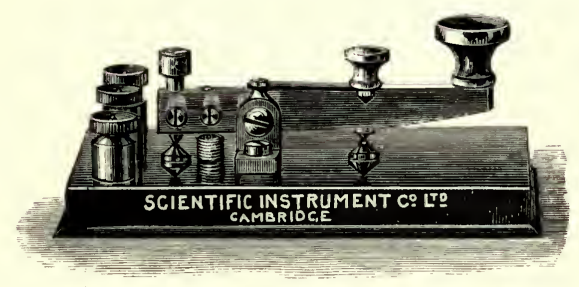

Fig. 75. No. 275 .

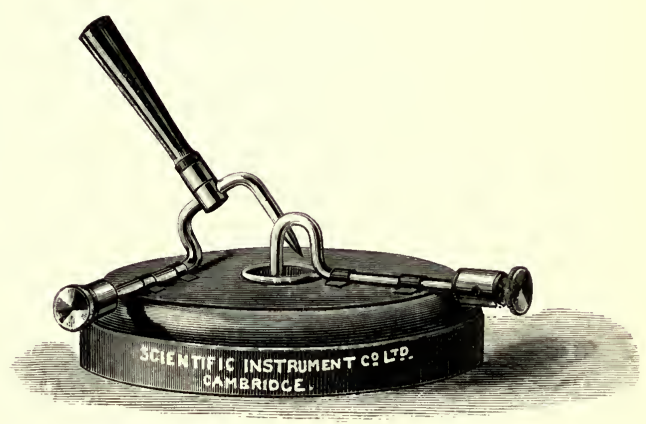

Fig. 76. No. 276 .

275. Morse Key. This is of the usual design, on ebonite base with platinum contacts. By the movement of a spring eatch the circuit can be kept closed (Fig. 75) ...

£2. 7s. 6d. Arsenious.

276. Mercury Key (Fig. 76) 15s. 0d. Artesian.

\section{Du Bois-Reymond's Friction Key.}

Without table clamp

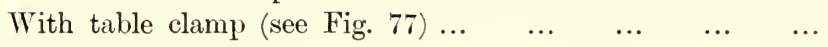

Cheap form ...

278. Single Contact Key, with spring lever on ebonite base and platinum contacts

Ditto with lever

279. Spring Key, cheap form $\ldots \quad \ldots \quad \ldots \quad \ldots$

£1. 1s. 0d. Artistic.

£1. 6s. 0d. Artlessly. 15s. 0d. Artspun.

280. Reversing Key, on ebonite base with platinum contacts (Fig. 78)

£2. 10s. 0d. Escartel.

281. Ditto mounted on ebonite pillars $\ldots \quad \ldots \quad \ldots \quad \ldots 3 . \quad 10$ s. 0d. Cleavable.

28:. $, \quad, \quad, \quad$, with cams for keeping circuit closed

$£ 4$. 0s. 0d. Clergyable.

283. Ditto with upper cross bar divided and fitted with plug so that the

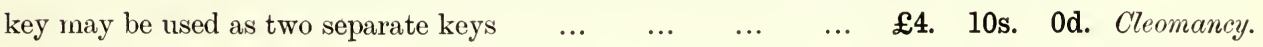


284. Short Circuiting Key, with locking arrangement

£1. 15s. 0d. Clewgarnet.

285. Ditto with contacts mounted on ebonite pillars ... $22 . \quad 15$ s. 0 d. Climatical.

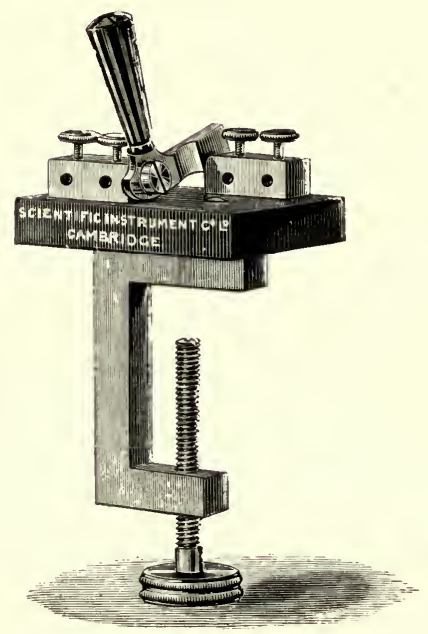

Fig. 77 . No. 277.

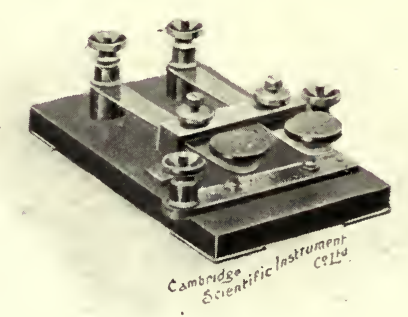

Fig 78. No. 280 .

286. Lambert's Discharge Key, for capacity testing £2. 10s. Od. Clog.

287. Do. do. with extra contact and cams for holding down levers

£3. 15s. Od. Clothespin.

288. Webb's Discharge Key with lever and contacts mounted on $\begin{array}{llllllllllll}\text { ebonite pillars } & \ldots & \ldots & \ldots & \ldots & \ldots & \ldots & \ldots & \ldots & £ 3 . & 10 \text { s. } & 0 d .\end{array}$

Galvanometer and Bridge Key, for measuring resistances. It is arranged to complete both the battery and galvanometer circuits in one operation. This is done in the right order to prevent the sudden throw in the galvanometer due to self-induction. With platinum contacts.

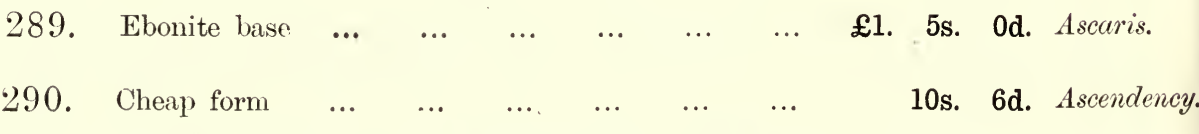

291. Griffiths' Thermo-Electric Key. When measuring low resistances thermo-electric effects sufficient to affect the accuracy of the observations constantly present themselves. By using this key the swing of the galvanometer is independent of all such causes of disturbance. The first movement of the key breaks the galvanometer circuit; then the battery circuit is closed, and 
lastly the galvanometer circuit is again closed. The key should be depressed quickly. (See Phil. Trans. Royal Society, Vol. 184 (1893) A, pp. 397-398.)

On ebonite base (Fig. 79)

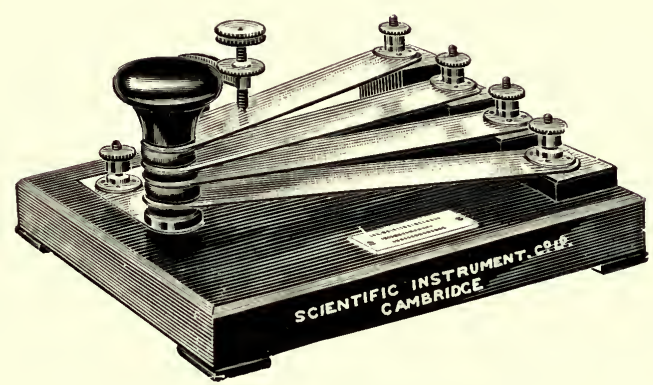

Fig. 79. No. 291.

\section{Griffiths' Combined Thermo-Electric Key and Com-}

mutator. This not only makes the contacts in the same cycle as the above, but also reverses the direction of the battery current at the completion of the cycle and then makes the contacts in the same order as before. This is all performed in

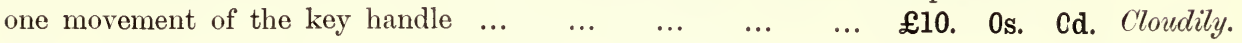

293. Knock-Over Key. A simple form of key which can be adapted to fix to the base of any of our Recording Cylinders. A projection fixed to the cylinder knocks the key open and breaks the circuit at a definite point in the revolution of the drum

£1. 15s. Od. Aspiring.

294. Pohl's Rocking Mercury Commutator, simple form (Fig. 80)

295. Do. do. improved, with large base, steel mercury cups, spring to

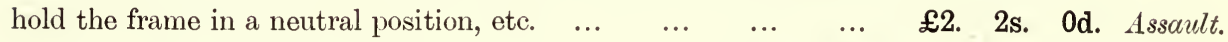

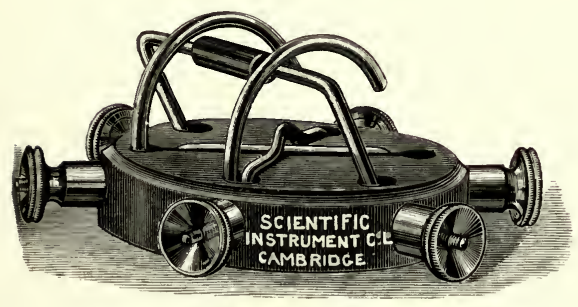

Fig. 80. No. 294.

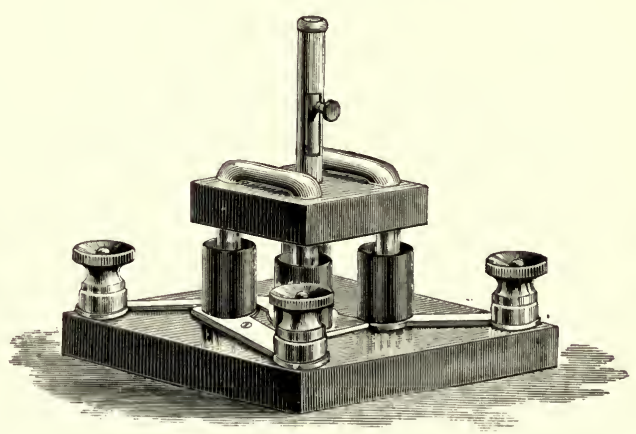

Fig. 81. No. 296. 
296. Mercury Commutator for use with large currents (Fig. 81) ...

£3. 5s. 0d. Assembling.

297. Plug Keys. One way $\quad \ldots \quad \ldots \quad \ldots \quad \ldots$

298. Ditto. Two way with two plugs 10s. Od. Ashery.

17s. 0d. Ashtar.

Porcelain Plug Key. In this form a divided fusible metal cup in a porcelain holder takes the place of the two brass blocks in the ordinary plug key. It is impossible for the plug to work loose as so often happens in the ordinary key, and at the same time a better electrical connection is made.

This type of plug is similar to those fitted to our Callendar and Griffiths' Resistance Boxes.
299. One way
16s. 6d. Ashy.
300. Two way with two plugs
£1. 12s. 0d. Aspersion.

Battery Plug Switches for altering the number of cells in a testing battery. A set of brass connecting blocks is mounted on an ebonite base and these are connected to the main bar by means of a plug. The small bars are fitted with a hole and screw for taking leads and the large bar with a double terminal.
301. Four way
£1. 7s. 6d. Clublaw.
302. Six way ...
£1. 17s. 6d. Coastwise.

Double Terminals mounted on long corrugated ebonite pillars, with ebonite base. These will be found very useful for testing sets.

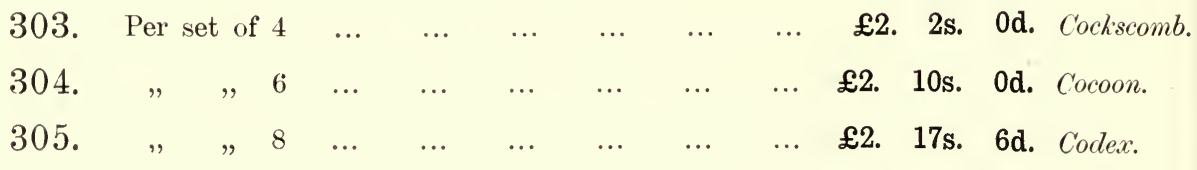

Any kind of commutator or plug blocks made to order, prices of which will be submitted on receipt of specification. 


\section{GALVANOMETERS, ETC.}

306. Ayrton-Mather D'Arsonval Galvanometer. Having made an agreement with Prof. Ayrton and Mr Mather we are now able to supply their latest type of D'Arsonval Galvanometer. 'These instruments are exceedingly sensitive, dead beat and suitable for accurate measurements of all kinds. Figure of merit from 5 to 10 millimetres deflection at a scale distance of $1000 \mathrm{~mm}$. caused by 1 micro-volt ... £11. 10s. Od.

Can be supplied with coils of various resistances suitable for either Resistance, Insulation Testing, or Ballistic work. Unless specified to the contrary the galvanometer will have a resistance of about $25 \mathrm{ohms}$.

With suspending lugs as shown in Fig. $82 \quad \ldots \quad \ldots \quad \ldots \quad$ extra 7 s. 6 d. Codist.

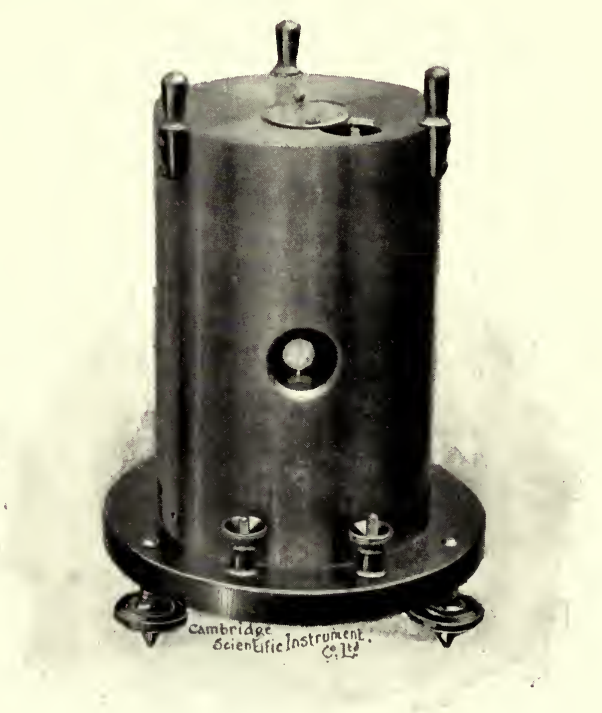

Fig. 82. No. 306 .

307. Ayrton-Mather D'Arsonval Galvanometer. In this form the suspended system is mounted in a tube in order that it may be quickly removed from the instrument to make room for one of a different resistance.

Unless ordered to the contrary, the galvanometer will have a resistance of about 25 ohms.

$\begin{array}{llllllllll}\text { Without tangent head } & \ldots & \ldots & \ldots & \ldots & \ldots & \ldots & £ \text { \&. } & \text { 0s. } & \text { 0d. Cokernut. }\end{array}$

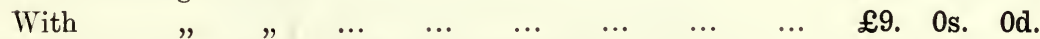

Spare coils having the following resistances are supplied in dust-tight tubes ready for insertion in Galvanometer:-

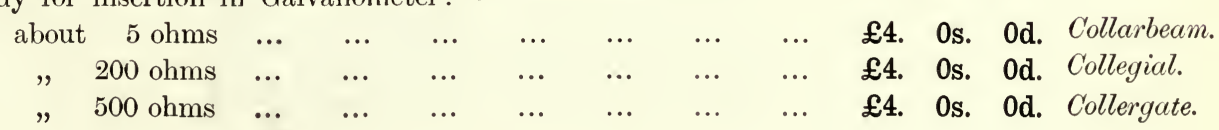


308. D'Arsonval Galvanometer. Cheap form, sensibility not less han one mm. per microvolt at one metre scale distance ... $\quad \ldots \quad$ \&5. 0 s. 0 d. Collodion.

309. D'Arsonval Galvanometer, on Tripod, with telescope and scale for field work as designed by Mr Mather. This instrument is adjusted to read directly in tenths of a millivolt per $\mathrm{cm}$. on the scale, with case complete

£20. 0s. 0d. Collusory.

\section{Thomson High Resistance Astatic Reflecting Galvano-}

meter. Fig. 83. This instrument is wound with 30,000 convolutions of wire and has a resistance of about 7,000 ohms. It is mounted on a wooden or ebonite

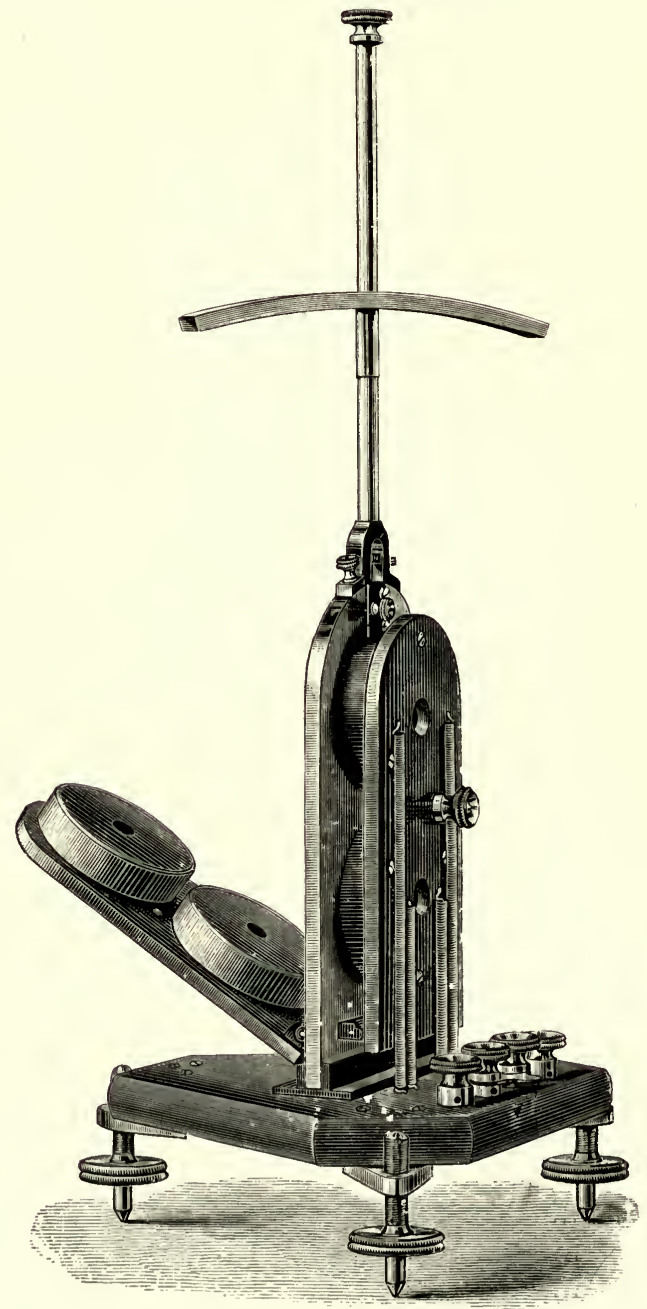

Fig. 83. Nos. 310, 311 . 
base supported by three levelling screws. The suspension which is extremely light consists of two systems, each containing 5 small magnets connected by an aluminium wire so as to form an astatic combination. The top system to which a light concave mirror is attached hangs in the centre of the upper pair of coils, and the lower at the centre of the lower pair.

The upper end of the fibre which supports the suspension is cemented to a pin capable of vertical adjustment and also of rotation; the pin with the fibre and suspension attached can be easily removed. The coils are fixed to two plates which turn on hinges at the bottom of the central plate, so that by simply removing two screws with milled heads, the plates supporting the coils can be turned back and the suspension inspected or removed. In order to increase the sensibility, the coils are wound with three sizes of wire.

On wooden base $\begin{array}{lllllll}\cdots & \ldots & \ldots & \ldots & \ldots & \ldots & £ 14\end{array}$

£14. 0s. 0d. Awful.

On ebonite base ... $\quad \cdots \quad \cdots$ $\ldots 15$.

Os. 0

od. Assentive.

\section{Thomson Low Resistance Astatic Reflecting Galvano-}

meter, similar to the High Resistance Galvanometer, except that the coils are wound with thick wire. Unless otherwise ordered coils with a resistance of $10 \mathrm{ohms}$ are supplied

$£ 14$. 0s. 0 d.

312. Thomson Galvanometer. Students' Pattern. This instrument has been especially designed to supply the want of a cheap but reliable galvanometer. It is fitted with two coils of a total resistance of about $10 \mathrm{ohms}$, levelling screws, magnet control, etc...

$£ 4$. 4s. 0 d.

313. Ballistic Galvanometer. This is similar to the instrument at the Cavendish Laboratory, originally designed by Prof. Clerk Maxwell. The two coils can be easily removed and the magnet exposed. The fibre is enclosed in a glass tube and is 60 centimetres long. It can be shortened by turning a screw. The magnet is carried in a brass stirrup, and by adjusting the positions of two small brass weights, the moment of inertia can be increased or diminished. Either silk or quartz fibres can be used. See Phil. Trans., Vol. 174, 1883, "Experiments on the value of the British Association Unit of Resistance." By R. T. Glazebrook and J. M. Dodds

314. Quartz Fibres, made by the method described by Mr C. V. Boys. These fibres have the great advantage of being apparently perfectly elastic. They are supplied on frames each containing six or more fibres.

Frame containing 6 fibres about $16 \mathrm{cms}$. long $\quad \ldots \quad \ldots . \quad \ldots \quad 5 \mathrm{~s}$. 0d. Attic.

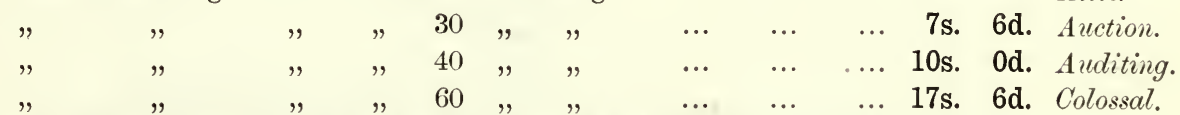

Stout quartz fibres for supporting weights up to 50 grammes are supplied at double the above prices.

315. Sine Galvanometer. The coil is wound on a brass ring $225 \mathrm{~mm}$. in diameter, and the two halves of the ring are insulated from each other. It is 
fixed to the divided circle so that the magnet is at its centre. The whole can turn in a frame standing on three levelling screws, and the angle of rotation about the vertical axis can be read

316. Tangent Galvanometer. Double ring. Gaugain pattern. Resistance of each coil $1 \mathrm{ohm}$.

The instrument can be used as a differential galvanometer, and the coils either in parallel or series

$£ 7.10$ s. 0d. Combating.

317. Tangent Galvanometer. Single Ring. Resistance 2 ohms. ...

£4. 4s. 0d. Combless.

318. Tangent Galvanometer. Students' form. Two coils of wire of different resistances are wound on the same ring, one being about 1 and the other $\begin{array}{llllllllllll}\text { about } 10 \mathrm{ohms} & \ldots & \ldots & \ldots & \ldots & \ldots & \ldots & \ldots & \ldots & £ 3 . & 10 \text { s. } & \text { 0d. Comfit. }\end{array}$

319. Shunt, Ayrton-Mather Universal Galvanometer. This shunt does not require to be adjusted to each galvanometer, but can be applied to any one, irrespective of its resistance. A great advantage of this form of shunt is that it is correct for ballistic work, the damping being constant whatever the shunt used.

It may also be used as a volt box, giving fixed proportions of the total volts at the terminals.

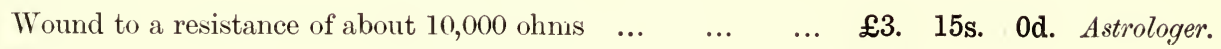

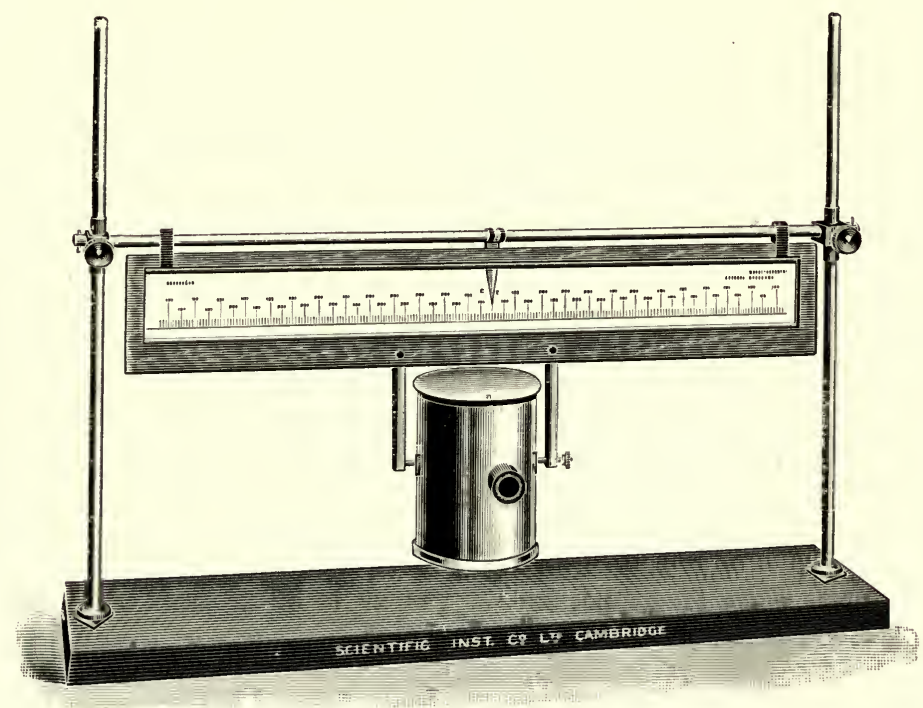

Fig. 84. No. 321. 
320. Lamp Stand, Transparent Scale, with oil lamp

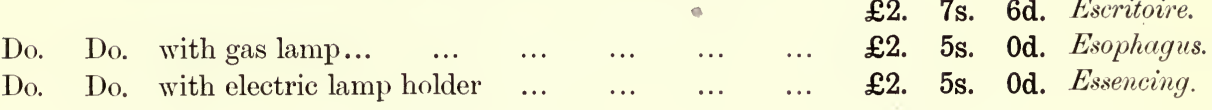

321. Lamp Stand, Transparent Scale $500 \mathrm{~mm}$. long, with incandescent lamp and condensing lens. Scale on tracing paper between two glass

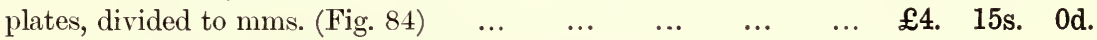

Do. do., but with scale $800 \mathrm{~mm}$. long; divisions equal to $1 \mathrm{~mm}$. ... $\quad \ldots$ £6. 10s. 0d. Etherole.

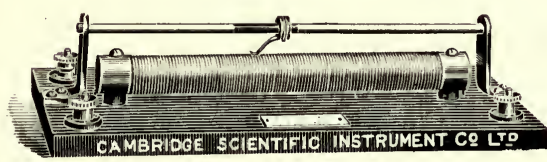

Fig. 85. No. 322 .
322. Rheostat. (Fig. 85). Consisting of a German silver wire wound on slate bar with sliding contact. Resistance about $30 \mathrm{ohms}$, suitable for insertion in battery circuits, etc. ... $\quad \ldots \quad \ldots \quad £ 1$. 10 s. 0 d.

Eternalist.

323. Du Bois-Reymond's Rheocord. Two platinum wires are stretched by the side of a scale one metre long fixed to a board. These wires are electrically connected together by an ebonite trough containing mercury which can slide along their length and the position of which can be read on the scale. By means of small resistances connected in series with the platinum wires the resistance of the Rheocord can be gradually increased from zero to a resistance equal to 42 metres of the platinum wire ...

£8. 10. 0d. Arraswise.

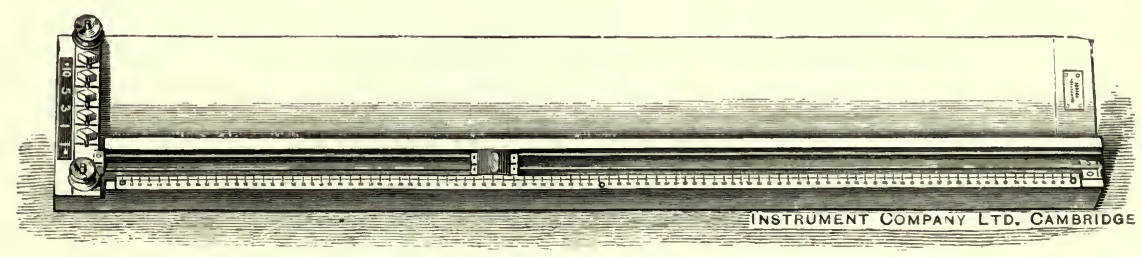

Fig. 86. No. 323.

324. Rheostat, Wheatstone's. This consists of a German silver wire which can be wound to any desired extent round an ebonite cylinder, contact being made with a small metallic wheel sliding along a rod. The number of complete and partial revolutions of the cylinder can be obtained

$£ 4.0$ s. 0d. Commark. 


\section{RESISTANCE BOXES, ETC.}

All resistances are adjusted to the Board of Trade or International Ohm, 1892, unless otherwise specified.

$1 \mathrm{Ohm}=1 \cdot 01358$ B.A. Units.

1 B.A. Unit $=9866 \mathrm{Ohm}$.

\section{THE "CAMBRIDGE" STANDARD COILS.}

These coils are wound with bare platinum silver wire of large size $(0.88 \mathrm{~mm}$. diameter) round a hexagonal frame made of stout mica and supported by a brass carrier. They are contained in a glass case with an ebonite top and are irnmersed in insulating oil. This arrangement ensures the coil being at the true indicated temperature as there is no lagging due to paraffin wax or silk covering. A thermometer hole is left in the top through which the oil can be introduced, and which also allows the bulb of the thermometer to be placed near the centre of the coil.

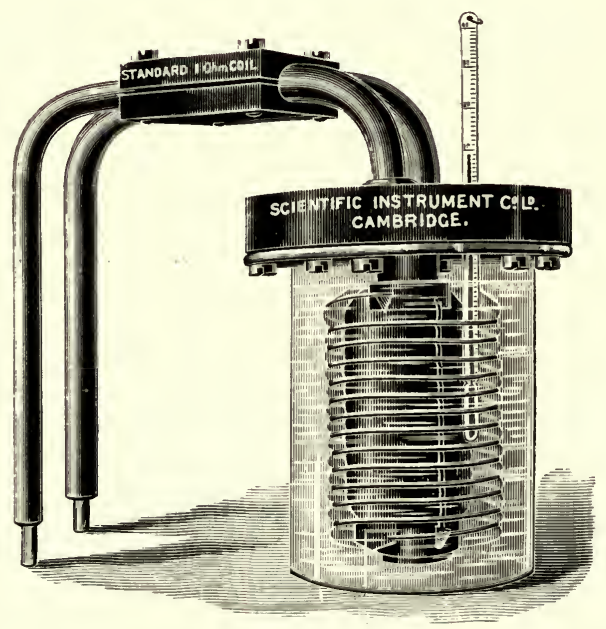

Fig. 87. No. 325 .

325. 1 Ohm (Fig. 87)

326. 10 Ohms

327. 100 Ohms
£6. 10s. 0d. Commixture.

£6. 10s. 0d. Compassed.

£6. 10s. 0d. Compliable. 


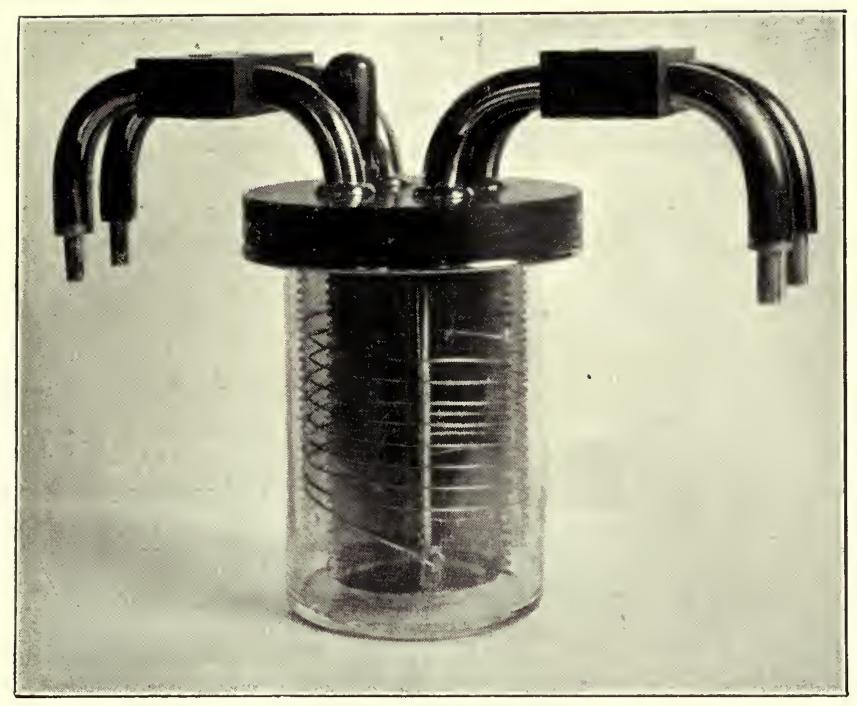

Fig. 88. No. 328 .

\section{Standard one $\mathrm{Ohm}$ with auxiliary coil of platinum} for determining the temperature, as supplied to the Board of Trade. See Electrician, Sept. 14th, 1900 and Brit. Assoc. Report, 1900, p. 55 (Fig. 88) ‥

£12. 0s. 0d. Concredit.

Case for any of the above coils 10s. 0d. Condoler.

All the above Coils are standardized either at the Board of Trade Laboratory or at the National Physical Laboratory and are accompanied with their certificate which is charged at cost price.

Single resistance coils, forming standards of moderate accuracy. These have been designed for use in conjunction with metre bridges and for work not requiring very great accuracy. They are made of manganin wound on bobbins, and mounted on wooden bases provided with terminals and copper strips; accuracy to $0.1 \%$.

$\begin{array}{lcccccccccc}329 . & 1 \mathrm{ohm} & \ldots & \ldots & \ldots & \ldots & \ldots & \ldots & £ 1 . & 1 \mathrm{~s} . & 0 \mathrm{~d} . \text { Conepate. } \\ 330 . & 10 \mathrm{ohms} & \ldots & \ldots & \ldots & \ldots & \ldots & \ldots & £ 1 . & 1 \mathrm{~s} . & 0 \mathrm{~d} . \text { Conferva. } \\ 331 . & 100 \mathrm{ohms} & \ldots & \ldots & \ldots & \ldots & \ldots & \ldots & £ 1 . & 10 \mathrm{~s} . & 0 \mathrm{~d} . \text { Configure. } \\ 332 . & 1000 \mathrm{ohms} & \ldots & \ldots & \ldots & \ldots & \ldots & \ldots & £ 1 . & 17 \mathrm{~s} . & 6 \mathrm{~d} . \text { Coopery. }\end{array}$


Ratio boxes for High Voltages.

\begin{tabular}{|c|c|c|c|c|c|c|c|c|}
\hline & Resistance & $\begin{array}{l}\text { D. of circuit } \\
\text { be measured }\end{array}$ & & & & & & \\
\hline 333. & 5,000 ohms & 110 volts & $\ldots$ & $\ldots$ & $\ldots$ & $£ 5$. & $0 \mathrm{~s}$. & 0d. Earthflax. \\
\hline 3 & 10,000 & 220 & $\ldots$ & $\ldots$ & $\ldots$ & $£ 6$. & 0s. & od. Easement. \\
\hline
\end{tabular}

Boxes for use on higher or lower potential circuits made to order.

\section{Low Resistance Shunts.}

$$
1-1000 \text { Accuracy to } 1-10000
$$

\begin{tabular}{|c|c|c|c|c|c|c|c|c|}
\hline 335. & ohm to & o carry & 10 amperes & £2. $2 \mathrm{~s}$. & od. & £4. 10 s. & $0 \mathrm{~d}$. & Eaudevie. \\
\hline 336. & " & , & 50 & $£ 4 . \quad 4 \mathrm{~s}$. & od. & £5. 10 s. & $0 \mathrm{~d}$ & Ebriety. \\
\hline .001 & , & " & 100 & $£ 5 . \quad 0$ s. & od. & £6. $6 \mathrm{~s}$. & od. & Echoed. \\
\hline$\cdot 0001$ & , & , & 1000 & $£ 15 . \quad 0$ s. & od. & $£ 20$. & $0 d$. & Echomete \\
\hline
\end{tabular}

339. High Resistance Box, square form, for use as constant box, wound with manganin wire and divided into four sections of 10,$000 ; 20,000 ; 30,000$ and 40,000 ohms respectively. Total Resistance $=100,000 \mathrm{ohms}$ £12. 0s. 0d. Corpuscle.

340. Ditto, with coil divided at the inside ends and connected up outside the case to test the insulation between the parallel windings... £12. 10s. Od. Corradial.

341. One Megohm divided into sections of 100,000; 200,000; 300,000 and 400,000 ohms, in manganin. All terminals mounted on corrugated ebonite pillars

342. One ohm subdivided into sections of $\cdot 1, \cdot 2, \cdot 3$ and $\cdot 4$ ohms respec-

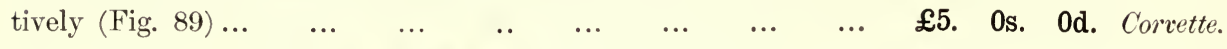

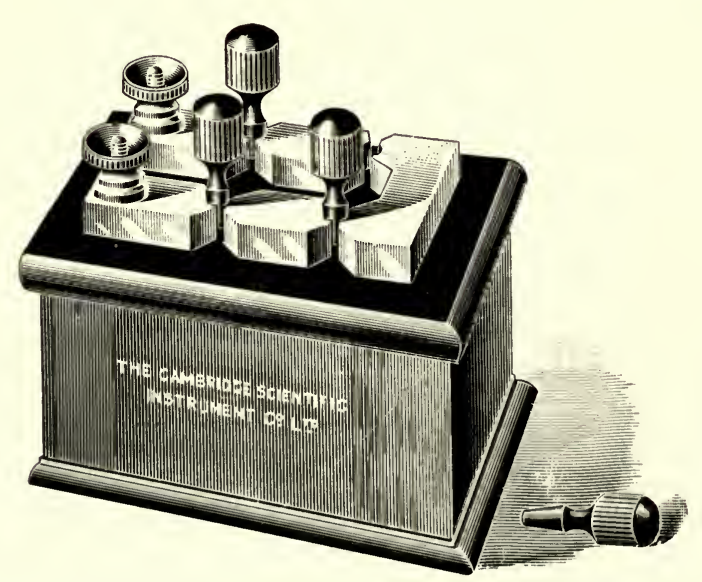

Fig. 89. Nos. 342-345. 
343. 10 ohms subdivided into $1,2,3$ and $4 \mathrm{ohms} \quad \ldots \quad £ 5.0$... 0 d. Fiskweed.

344. 100 ohms subdivided into 10, 20, 30 and $40 \mathrm{ohms} £ 5$. 10s. 0d. Carybant.

345. 1000 ohms subdivided into 100, 200, 300 and $400 \mathrm{ohms} \ldots \quad \ldots$

£5. 10s. 0d. Cosmic.

346. Set of Resistance Coils from $1 \mathrm{ohm}$ to 4,000, arranged in rows giving any combination from $1 \mathrm{ohm}$ to $11,110 \mathrm{ohms}$ (Fig. 90).

$\begin{array}{lllllllllll}\text { In platinoid } \ldots & \ldots & \ldots & \ldots & \ldots & \ldots & \ldots & \ldots & £ 15 . & 10 \text { s. } & 0 \text { d. Cottonous. }\end{array}$

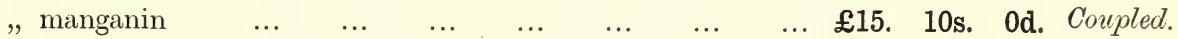

$\begin{array}{lllllllllll} & \text { " platinum silver } \ldots & \ldots & \ldots & \ldots & \ldots & \ldots & \ldots & £ 19 . & \text { 0s. } & 0 \text { d. Congar. }\end{array}$

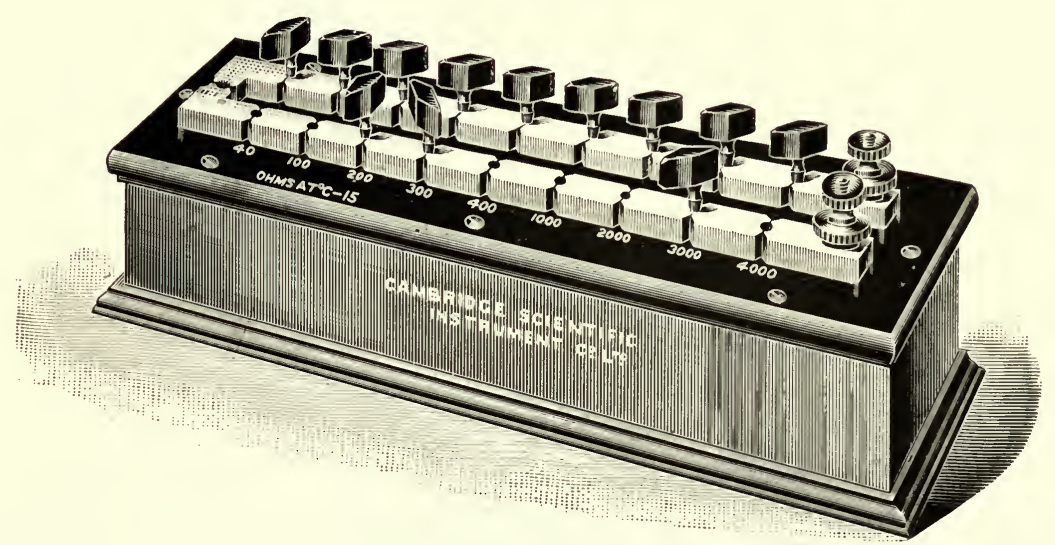

Fig. 90. No. 346 .

347. Set of Resistance Coils for High Tension Work, 1 to 10,000 ohms. The blocks in this case have large air gaps and the plugs are

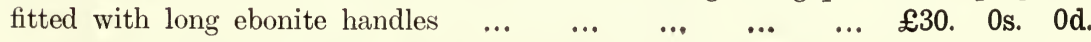

Unless specially ordered to the contrary this box is fitted with plugs similar to those shown in No. 346.

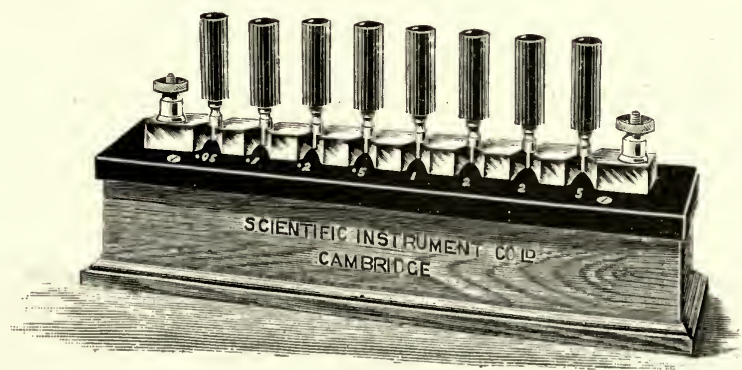

Fig. 91. No. 348 , 
348. Resistance Box, primarily designed for use with the Duddell Oscillograph. The plugs are fitted with long ebonite handles. Coils $0 \cdot 1,0 \cdot 2,0 \cdot 2$, $0 \cdot 5,1 \cdot 0,2 \cdot 0,2 \cdot 0$ and 5 ohms. These coils are correct to $0 \cdot 25$ per cent. (Fig. 91 ). ...

£4. 4 s. 0d. Defigo.

349. Post Office Bridge with three sets of proportional coils of 10 , 100 and $1000 \mathrm{ohms}$ and adjustable resistance of 1 to $10,000 \mathrm{ohms}$, with infinity plug and plug current reverser, in mahogany case, wound with platinoid wire (Fig. 92)

£23. 0s. 0d. Coystrel.

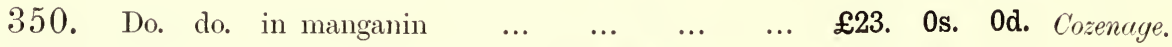

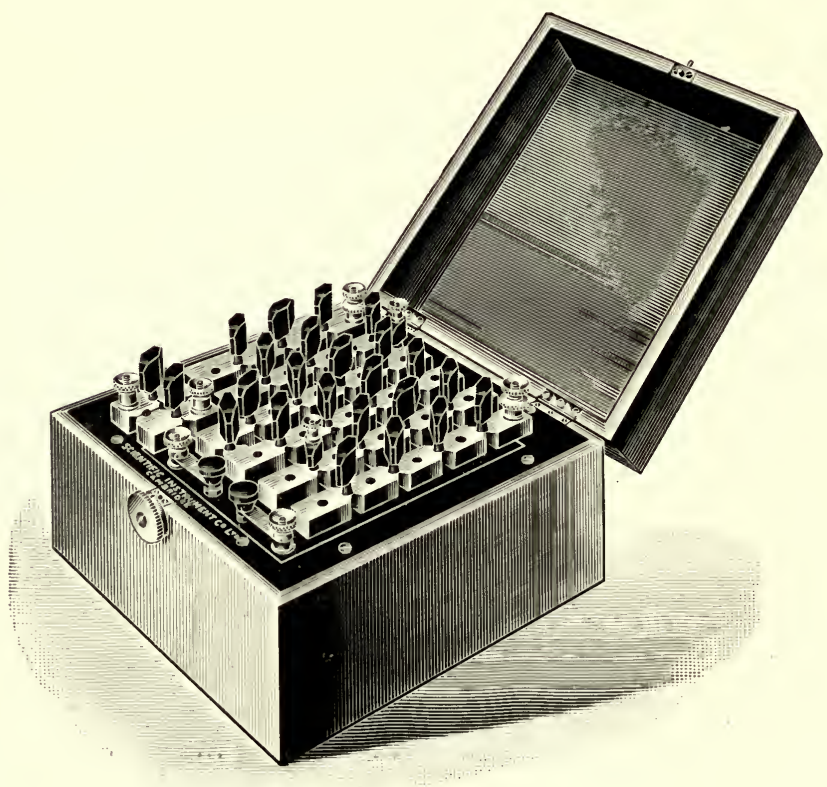

Fig. 92. Nos. 349, 350 .

351. Students' Pattern Bridge. Platinoid wire, wooden base,

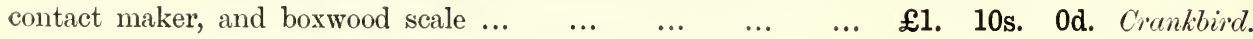

352. Metre Bridge. Copper parts heavier; platinoid wire, better contact maker, mahogany base, boxwood scale $\ldots \quad \ldots \quad \ldots \quad$ \&5. 0 s. 0 d. Crapaudin

353. Do. with platinum silver wire $\ldots \quad \ldots \quad \ldots \quad £ 6.10$ s. 0d. Crawfish.

354. Poggendorff's Metre Bridge $\ldots \quad \ldots \quad$ £6. 0s. 0d. Gibbose.

355. Carey-Foster Bridge ... ... ... firom £20. 0s. 0d. Creeky. 
Wheatstone Bridges. We have, after due consideration discarded the ordinary round dial form of bridge and have adopted in preference the bar dials originally suggested by Prof. Anthony. This form admits of cleaning between the brass blocks more readily. The ratio coils are placed together at one end of the box to ensure them all being at the same temperature. We make these boxes in two distinct types, one in which the coils are made of bare platinum-silver wire wound on mica frames and immersed in insulating oil, enabling the temperature of the coils to be determined with great accuracy; the second in which the coils are made of either silk-covered platinum-silver or manganin wire wound on bobbins and coated with paraffin wax.

356. Wheatstone Bridge. Five dials, giving tenths, units, tens, hundreds and thousands. Silk-covered platinum-silver coils wound on bobbins;

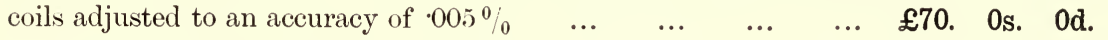

Crevasse.

357. Ditto, with all coils adjusted to an accuracy of $\cdot 05 \%$

£60. 0s. 0d. Crimsoned.

358. Wheatstone Bridge, similar to No. 356, with coils made of manganin covered with paraffin wax, coils adjusted to $05 \%$

$£ 50$. 0s. 0d. Cringeling.

359. Wheatstone Bridge. Four dials giving tenths, units, tens, and hundreds. Platinum-silver coils, wound on mica frames and immersed in oil ; coils

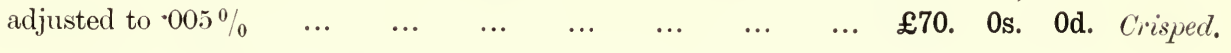

360. Wheatstone Bridge. Four dials giving units, tens, hundreds and thousands. Silk-covered platinum-silver coils wound on bobbins. Ratio coils

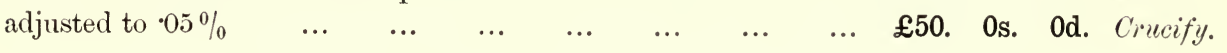

361. Wheatstone Bridge, similar to No. 360 , with coils made of manganin covered with paraffin wax; coils adjusted to $05 \%$ £40. 0 s. 0 d. Crummy.

This bridge is especially adapted for use in central station work.

362. Three Dial Resistance Box, units, tens and hundreds for the rough measurement of resistances; for insertion in battery circuits, etc.;

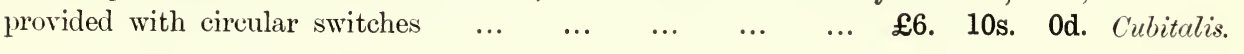

363. Ditto with 4 dials, giving units, tens, hundreds and thousands

£10. 0s. 0d. Cuckoobud.

364. Electrolytic Resistance, Cells for measurement of. See Stroud and Henderson, Phil. Mag. Vol. xuII. p. 19, 1897 12s. 6d. Cuerpo. 


\section{CALLENDAR AND GRIFFITHS' SELF-TESTING BRIDGES.}

These bridges have been designed by Prof. Callendar, F.R.S. and Mr E. H. Griffiths, F.R.S., for the accurate measurement of small resistances. We believe that it is possible by their means to determine electrical resistance with a degree of accuracy hitherto unattainable with ordinary boxes except under special circumstances.

The most striking advantages over other resistance boxes are as follows :

The observer can at any time ascertain the exact comparative error of all the coils.

Resistances less than $0.05 \mathrm{ohm}$ are determined by a bridge-wire of which an accurate calibration can at any time be performed by means of the box itself.

The actual temperature of the coils can be accurately determined and no temperature regulator is required.

The resistance of the leads connecting the box with the object to be measured is self-eliminated.

Resistances from 0.00001 to $105 \mathrm{ohms}$ (and if required, higher resistances) can be read directly by a "null" method, without observation of galvanometer swings.

The unit of the box is $\frac{1}{100} \mathrm{ohm}$, corresponding to a movement of one centimetre of the contact-maker on the bridge-wire; the smallest coil has a value of five such units. Each coil is double the one preceding it, and the values are as follows:

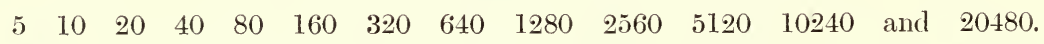

Many advantages are secured by adopting this binary scale, the chief of which is that the observer acquires the power of testing the coils, for each should differ by a fixed quantity from the sum of those beneath it. The number of coils supplied in a box varies with the price of the instrument.

The vernier gives direct readings to $\frac{1}{1000}$ of a unit, i.e. $0.00001 \mathrm{ohm}$. A special contact-maker, carrying a fine adjustment has been designed for this box, which even if roughly used, renders injury to the bridge-wire almost impossible.

A full description of the method of determining the coil errors etc., is supplied with these bridges.

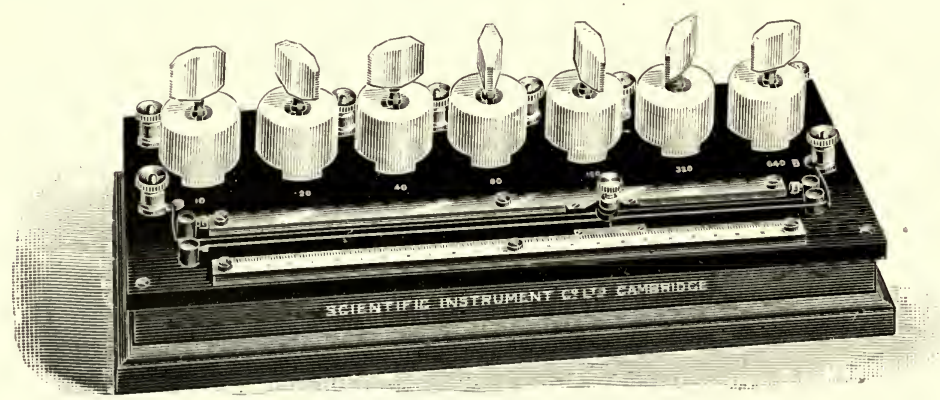

Fig. 92 u. No. 365 .

\section{Callendar and Griffiths' Self-testing Bridge (Students'}

Pattern). This bridge, as its name implies, has been designed especially for the 
use of students; it can be relied on to measure resistances to within $001 \mathrm{ohm}$. It consists of a wooden base on which are fixed seven porcelain plug holders attached to the Resistance Coils and numbered 10, 20, 40, 80, 160, 320 and 640 (sum of coils $=12.7 \mathrm{ohms}$ ). The coils are wound in small hanks lightly dipped in paraffin wax. They are suspended in air. The Galvanometer and bridge-wires are stretched between two adjustable brass strainers. The scale is divided on wood and reads to millimetres (Fig. $92 a$ ) $\quad \ldots \quad \ldots \ldots \ldots l$...

Do. Do. if fitted with simple glass case to cover the instrument when not in use

\section{Callendar and Griffiths' Self-testing Bridge, Pattern II.}

In this bridge (Fig. 93) the coils are made of silk-covered manganin wire wound on bobbins suspended in air. Porcelain plug-holders mounted on ebonite are attached to the coils. They are numbered in units on the binary scale (each unit being $0.01 \mathrm{ohm}$ ) $5,10,20,40,80,160,320,640,1280$. (Sum of coils $=25.5 \mathrm{ohms}$.) The ratio-arm coils $10 \mathrm{ohms}$ are also wound together on a bobbin. A resistance of 50 or $100 \mathrm{ohms}$ can be inserted in the battery circuit by means of a switch fixed in the bridge for that purpose.

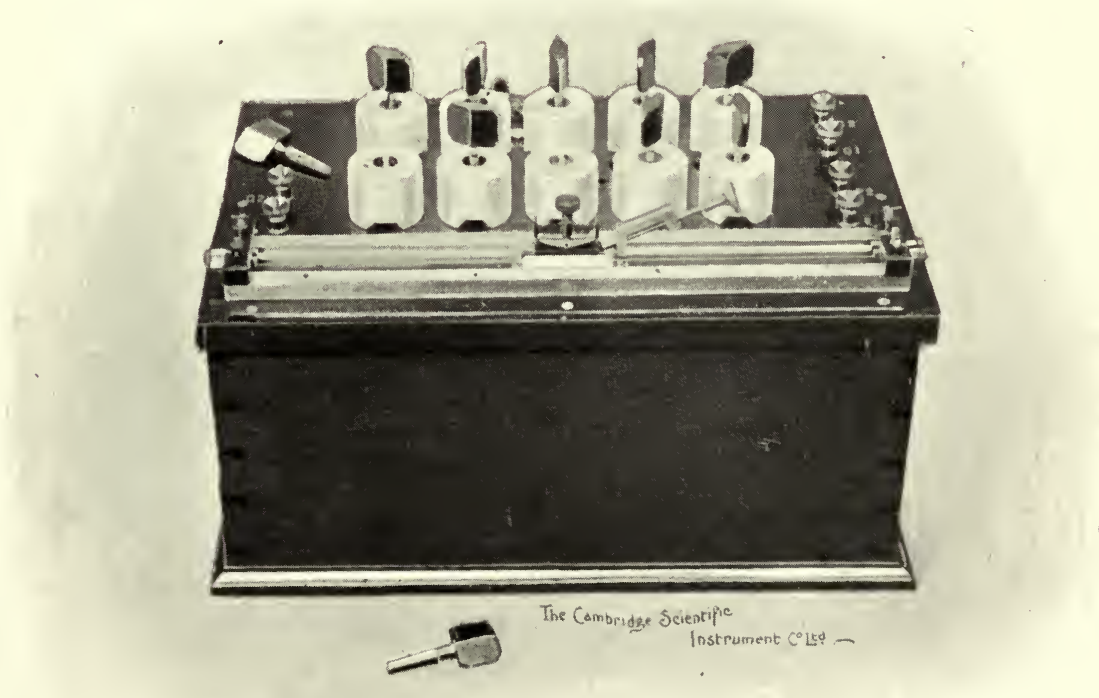

Fig. 93. ' Nus: 366,367 . 
The scale and vernier are of brass, the vernier reading to $0 \cdot 1 \mathrm{~mm}$.

$\begin{array}{lllllllll} & & & & & & & & \\ \text { Glass case with sliding door, } & \ldots & \ldots & \ldots & \ldots & \text { extra } & £ 3 . & \text { 10s. } & \text { 0d. Enhydious. } \\ \text { Silver scale and vernier, extra } & \ldots & \ldots & \ldots & \ldots & \text { extra } & £ 2 . & \text { 0s. } & \text { 0d. Ephemerous. }\end{array}$

\section{Callendar and Griffiths' Self-testing Bridge, Pat-} tern III. This bridge (Fig. 93) is similar to No. 366 with the important exception that the coils are bare platinum silver-wire immersed in a highly insulating oil. Their temperature can thus be determined to a high degree of accuracy. If desired, a stirring arrangement can be fitted for stirring the oil. Ratio-arm coils of $5 \mathrm{ohms}$ resistance are supplied unless ordered to the contrary $\quad \ldots \quad \ldots \quad \ldots 52.10$ s. 0 d. Epicurism.

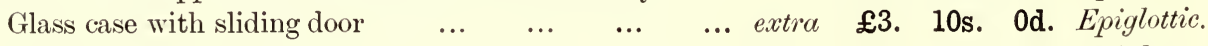

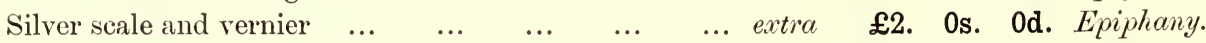

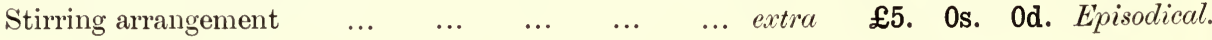

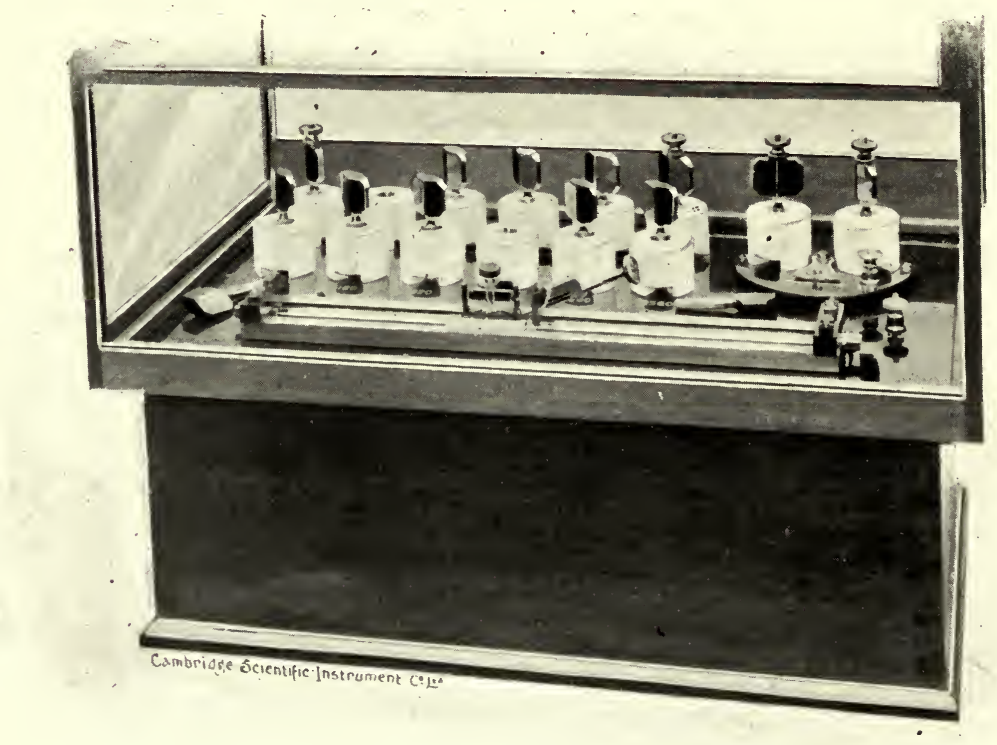

Fig. 94. No. 368 .

\section{Callendar and Griffiths' Self-Testing Bridge, Pat-}

tern IV. This bridge (Fig. 94), is similar to No. 367 but with the addition that the equal arms are removable. The latter are mounted in a case which can be taken away from the bridge, another set of coils replacing them. An arrangement 
is fitted for accurately adjusting the equality of the equal arm coils. A silver scale and vernier is fitted to this box.

Price with one set of equal ratio-arm coils $(5 \mathrm{ohms}) \quad \ldots \quad \ldots \quad \ldots 62 . \quad 10$ s. 0 d. Epitomizer.

Additional set of ratio-arm coils in case ready to be fitted to resistance box, extra £10. 0s. 0d. Equitation.

(In ordering state whether 5, 10, 20 or $50 \mathrm{ohm}$ ratio-arm coils are required.)

Glass case with sliding door, extra $\quad \ldots \quad \ldots \quad \ldots \quad \ldots$ extra $\quad £ 5 . \quad$ 0s. 0d. Equivoque.

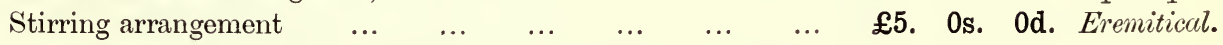

\section{Callendar and Griffiths' Self-testing Bridge, Pattern V.}

This bridge is larger than those previously described and is capable of measuring resistances from $400 \mathrm{ohms}$ downwards with an accuracy of $0.00001 \mathrm{ohm}$.

The coils are wound on mica frames and immersed in oil, and are numbered in units on the binary scale (each unit being $0.01 \mathrm{ohm}$ ) from 5 to 20480 , making a total resistance of $409.55 \mathrm{ohms}$.

The equal ratio-arm coils - three sets of which are supplied with the bridge, viz. 5, 50 and 100 ohms-have a very delicate screw adjustment for adjusting their equality.

Means are also provided for reversing the equal arm coils. A stirrer is fitted in the oil-bath which is packed with asbestos lining to assist in maintaining the temperature of the box constant.

An improved form of contact-maker and protecting cover for the bridge-wire largely increases the accuracy obtainable with the bridge.

Instrument complete with silver scale, glass case and sliding door

$£ 120$. 0s. 0d. Eirdanus.

This box is very similar to the one constructed for the Royal College of Science, South Kensington.

370. Plug hole cleaners for cleaning the plug holes of the Callendar and Griffiths' Bridges ...

2s. 6d. Erructate.

371. Standard Cadmium Cell, designed by Prof. Callendar.

This cell recovers itself very rapidly if accidentally short circuited. No temperature correction is required over the usual range of laboratory temperatures.

E. M. F. $=1.019$ volts. In brass case, complete $\ldots \quad \ldots \quad \ldots \quad £ 2 . \quad 10$ s. 0 d. Eelspear.

\section{Accumulators.}

Single Cell

11 Q Type Plates

$\begin{array}{ccc}\text { Charge } & \begin{array}{c}\text { Maximum } \\ \text { Discharge }\end{array} & \begin{array}{c}\text { Capacity } \\ \text { Ampere- } \\ \text { hours. }\end{array} \\ \text { Amperes. } & \text { Amperes. } & \text { hours } \\ 4 \text { to } 6.5 & 6.5 & 35\end{array}$

Cells lead lined) wood boxes $\}$
16 to 22
22

\author{
Weight \\ complete \\ with acid. \\ 16 lbs. ...
}

15s. 6d. Efface.

113 lbs. ...

£2. 2s. Od. Effectrix.

These cells have been found to give the most satisfactory results for general laboratory use. 
373. Daniell Cell, Gravity type. 3 quart. Е.м. F. 1.08 volts. Internal Resistance $1 \cdot 6 \mathrm{ohms}$, each complete ...

5s. 3d. Effendi.

374. Dry Cells, E.c.c. type, size No. 2, E. I. F. 1.55 volts, each

3s. 3d. Efferent.

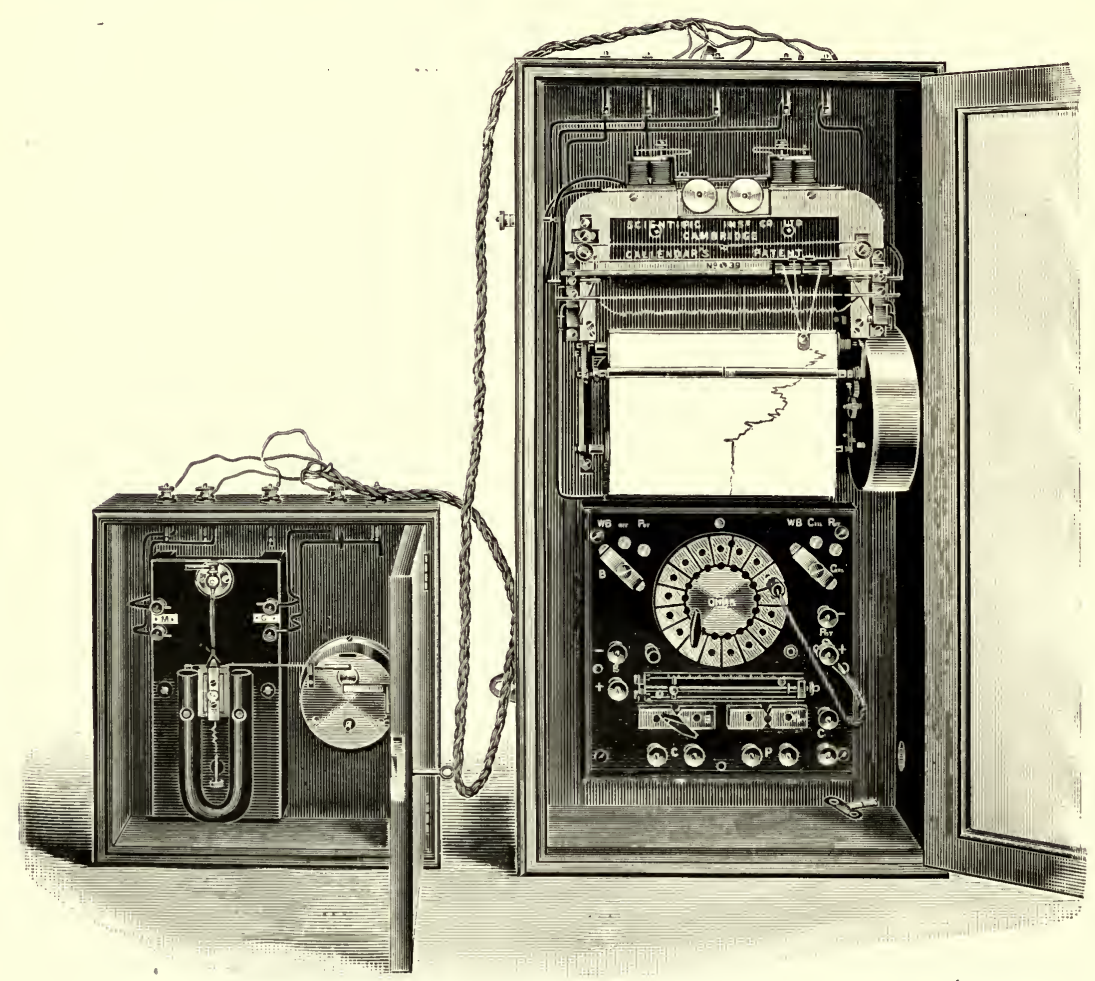

Callendar's Electric Recorder, with Potentiometer and Wheatstone Bridge switchboard and separate galvanometer.

Callendar's Electric Recorder. A Recording Wheatstone Bridge and Recording Potentiometer. This instrument can be used to record sunshine, variations in steam-pressure, current, potential, tide-level or temperature, or any varying physical quantity which can be reduced to the determination of an electrical resistance or potential difference.

Special list containing full description, prices, etc., of the above instrument sent post free on application. 


\section{SEISMOGRAPHS.}

These instruments were originally designed by Professor Ewing, F.R.S., for the Seismological Observatory of the University of Tokio. The forms now offered contain many improvements in detail, suggested by experience of earthquake measurement.

393. Horizontal and Vertical Motion Seismograph. The apparatus shown in Fig. 103 records two rectangular horizontal components and the vertical component of each successive displacement of the ground. The records are taken on a revolving plate of smoked glass which can be removed and replaced without disturbing the rest of the apparatus. A delicate seismoscope starts the plate revolving at the commencement of the shock and also starts a clock which beats seconds.

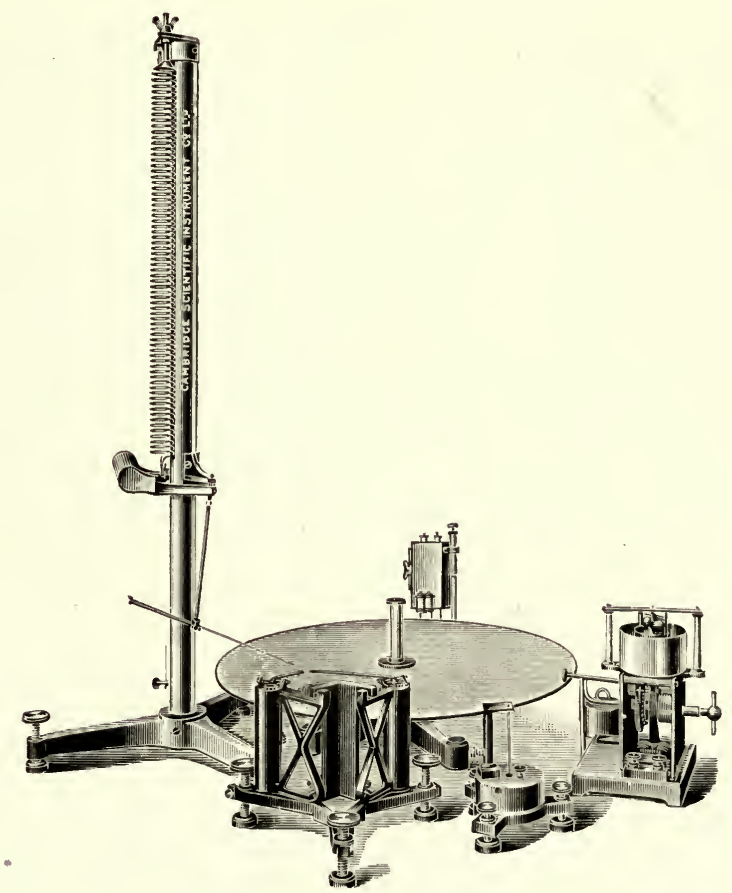

Fig. 103. No. 393.

Two spare plates are supplied with each seismograph.

Fig. 104 is an example of a small part of a record of an actual earthquake as given 
by the two horizontal pendulums of a seismograph; the straight radial lines repre-

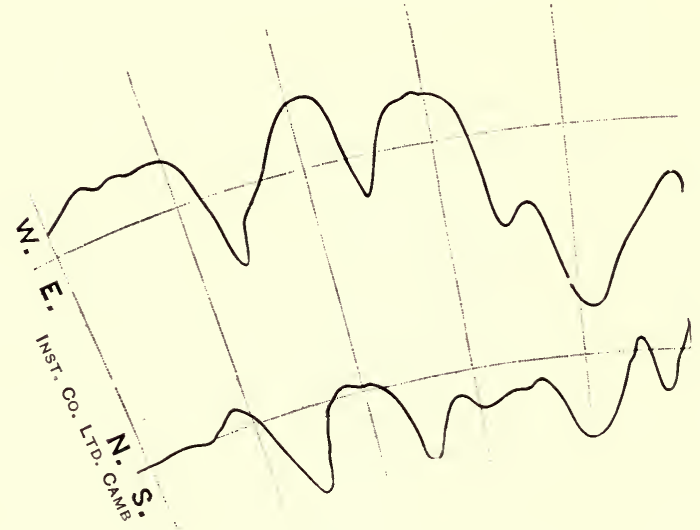

Fig. 104.

Many of these instruments are working successfully in various parts of the globe.

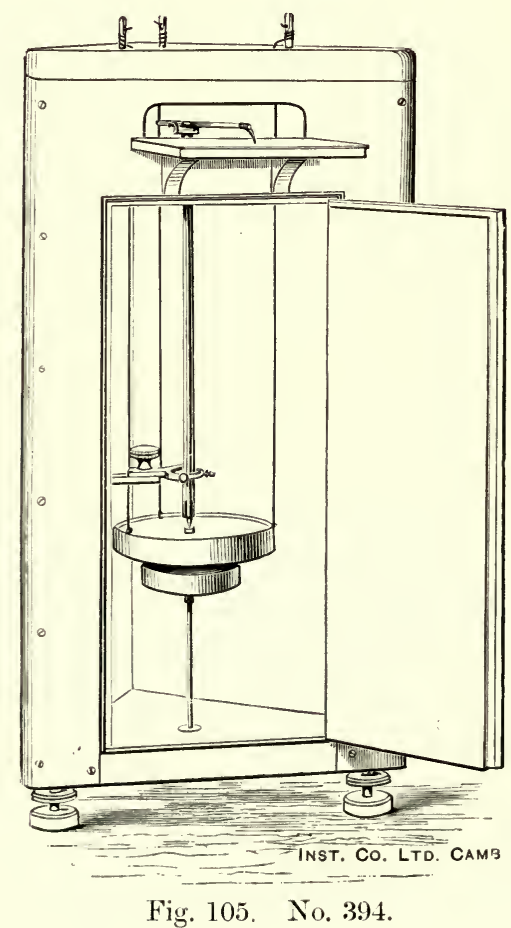


For a further description of Professor Ewing's Seismographs see "Earthquake Records for use in Observatories," by Prof. Ewing, Nature, Vol. 34, p. 343.

See also Papers by Professor Ewing in the Proceedings of the Royal Society for 1881 , p. 440 , and 1888 , p. 400.

394. Duplex Pendulum Seismograph. This is an instrument for registering, on a fixed plate of smoked glass, and with suitable magnification, the whole horizontal motion of the ground. A bob consisting of a massive disc, hung by three parallel wires from fixed supports, is geared by a ball and tube joint to an inverted pendulum pirotted in a hard steel cup in the base of the instrument. The two bobs are proportioned so that the combination swings, in any azimuth, in nearly neutral equilibrium. A recording lever is carried by a gimbal joint above the hanging bob: its short end gears into the bob by a ball and tube joint; its long end carries a pointer which traces a multiplied record of the motion on a fixed plate. The degree of stability of the combination is adjusted by raising or lowering the

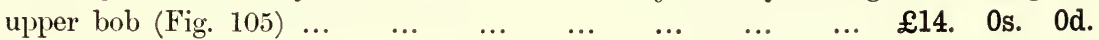

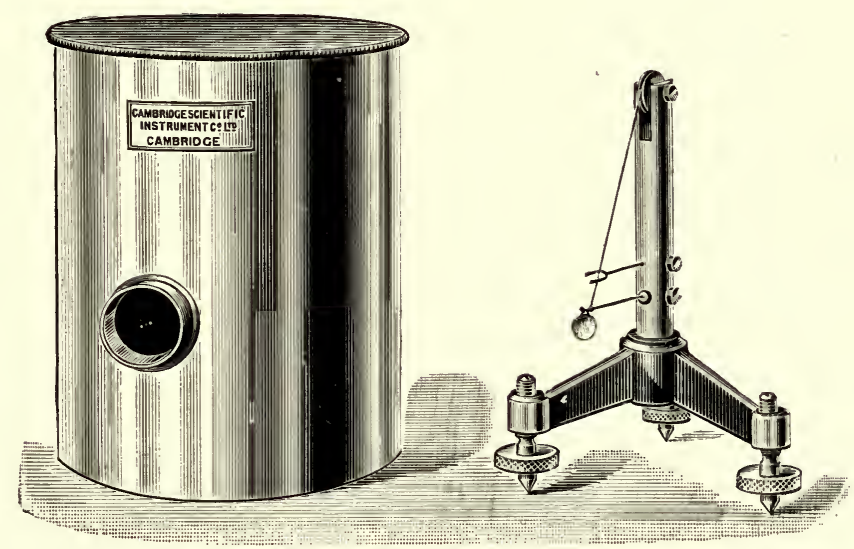

Fig. 106. No. 395.

395. Tromometer. This instrument was designed by Professor J. Milne for indicating small movements of the earth's surface. A needle rests with its point in an agate cup and is supported in a horizontal position by a fine silk fibre fixed to its other end. Movements of the support on which the instrument rests are indicated by the movement of a mirror carried on the extremity of the needle. Fig. 106. See B.A. Report, 1892, p. 108.

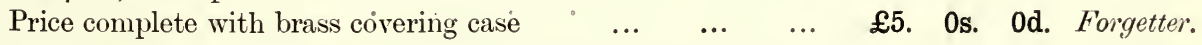

396. Photographic Recording Apparatus for receiving records from the Tromometer, complete with lamp $\quad \ldots \quad \ldots . \quad \ldots \quad £ 35$. 0s. 0d. Bailbond. 


\section{Bifilar Pen-}

dulum. This instrument was designed for observing and recording slow tilts and pulsations of the earth's crust, by whatever cause they may be produced. It is possible to observe with this pendulum a tilt of less than $\frac{7}{300}$ of a second, an angle less than that subtended by a line an inch long placed at a distance of a thousand miles (Fig. 107)

$£ 45$. 0s. 0s.

\section{Photographic} Recording Apparatus for use with the above, complete with lamp

£35. 0s. Od.

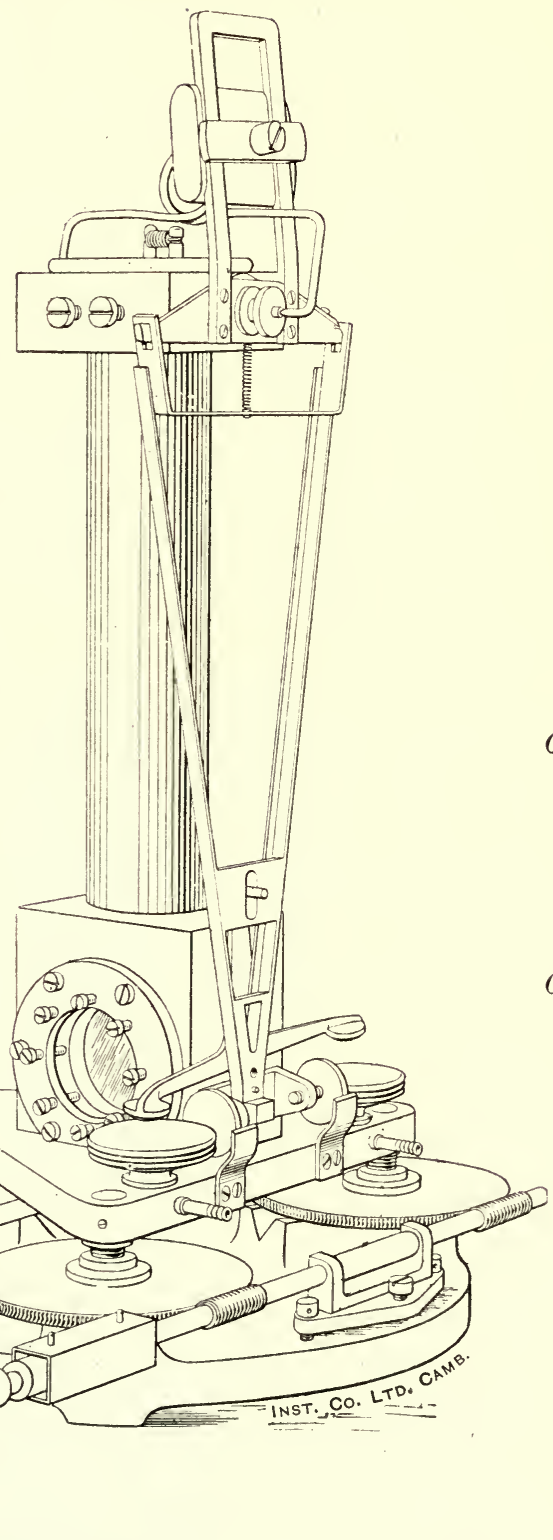

Cyclopti

Cymar.

Fig. 107. No. 397.

Seismological Instruments of any special type, and apparatus to measure the vibrations of buildings, made to order. 


\section{INDEX.}

A.

Acceleration Experiments, Apparatus

for $\quad . . \quad \ldots \quad \quad \ldots \quad \quad \ldots \quad 33-34$

$\begin{array}{lllll}\text { Accumulators } & \ldots & \ldots & \ldots & 88\end{array}$

Adjustable Glass Table ... $\quad \ldots .11$

$\begin{array}{llll}\text {, } & \text { Simple Stands ... } & \ldots & 10\end{array}$

Air Pumps-Fleuss' Vacuum _.. 37

$\begin{array}{lllll}\text {, } \quad \text {, Sprengel's } \quad \ldots & \ldots & 36\end{array}$

Air Thermometers, Constant Volume 61

, $\quad$, $\quad$ Jolly's ... $\quad \ldots \quad 61$

Amsler's Planimeter $\quad \ldots \quad \ldots .606$

Anderson Stuart's Kymoscope ... 40

Apparatus for marking off standard length on test pieces (Extensometer) $\quad \ldots \quad \ldots \quad \ldots \quad \ldots \quad \ldots \quad 25$

Atwood machines $\ldots \quad$... $\quad \ldots \quad 33$

Ayrton-Mather D'Arsonval Galvanometers $\quad \ldots \quad \ldots \quad \ldots \quad 73,74$

Ayrton-Mather D'Arsonval Galvanometer Shunt $\quad \ldots \quad \ldots \quad \ldots .76$

B.

Balance, Jolly's Specific Gravity 36 ,, of Machinery Apparatus 35

Ball-ended Magnets ... $\quad$... $\quad \ldots \quad 68$

Ballistic Balance, Compound ... 32

,, $\quad, \quad$ Hicks' ... $\quad$.. 32

,, Galvanometer ... ... 75

, $\quad$ Pendulum ... $\quad \ldots \quad$... 32

$\begin{array}{lllll}\text { Bar Callipers } & \ldots & \ldots & \ldots & 7\end{array}$

$\begin{array}{llllll}\text {,, Magnets ... } & \ldots & \ldots & \ldots & 68\end{array}$

$\begin{array}{llllll}\text { Bass Bow } & \ldots & \ldots & \ldots & \ldots & 42\end{array}$

Bath for varnishing tracings $\quad \ldots \quad 16$

Battery Plug Switches _.. $\quad \ldots \quad 72$

Beam, Continuous Apparatus _.. 31

$\begin{array}{llllll}\text {, Loaded } & \ldots & \ldots & \ldots & 30\end{array}$

Beams, Deflection of $\quad$.. $\quad$. 30

,, Ela'stic Bending of $\quad 29-30$
Beckmann's apparatus for freezing

point of solutions $\quad \ldots \quad \ldots 6 \quad 65$

Bench, Optical $\quad \ldots \quad$... $46-48$

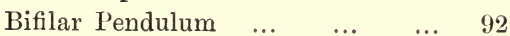

, Suspension, apparatus for 35

Bi-metallic Electric Regulator ... 53

Boxes, Resistance ... ... $\quad 78-87$

Boyle's Law apparatus $\quad \ldots \quad 60,61$

Boys' Geometric Stands ... ... 11

,, Radio-Micrometer ... $\quad$.. 64

, Wheel of Lenses _... $\quad$... 46

Bridges, Callendar and Griffiths' $84-87$

, Carey Foster ... ... 82

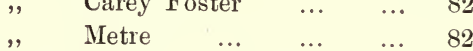

" $\quad \begin{array}{llll}\text { Poggendorff's } & & \cdots & \\ & & & \end{array}$

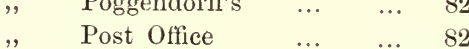

", $\quad$ Pyrometer ... $\quad$ (.. $41-87, \quad, 57-59$

, $\quad$ Self-Testing _.. $\quad 84-87$

,, Student's Pattern _.. 82

,, Wheatstone _.. $\quad 82,83$

Brodie's Time-marking Clock $\quad \ldots \quad 20$

Bunsen's Photometer _.. $\quad \ldots \quad 45$

C.

$\begin{array}{lllll}\text { Cadmium Cells } & \ldots & \ldots & \ldots & 87\end{array}$

Calibration of Mercury Thermo$\begin{array}{llllll}\text { meters } & \ldots & \ldots & \ldots & \ldots & 60\end{array}$

Callendar's Electric Recorder ... 88

Callendar and Griffiths' Platinum

Thermometers ... $\quad . . \quad$... 55

Callendar and Griffiths' Self-Testing

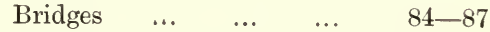

Callendar and Griffiths' Temperature

Indicator $\quad . . \quad \ldots \quad \quad \ldots \quad 57-59$

Callipers, Bar $\quad \ldots \quad$... $\quad \ldots \quad 7$

$\begin{array}{ccccc}\text { Pocket } & \ldots & \ldots & \ldots & \\ \text { Calorimeter-Coal } & \ldots & \ldots & \ldots & 54\end{array}$

,, Dulong and Petit's.. 54

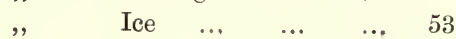




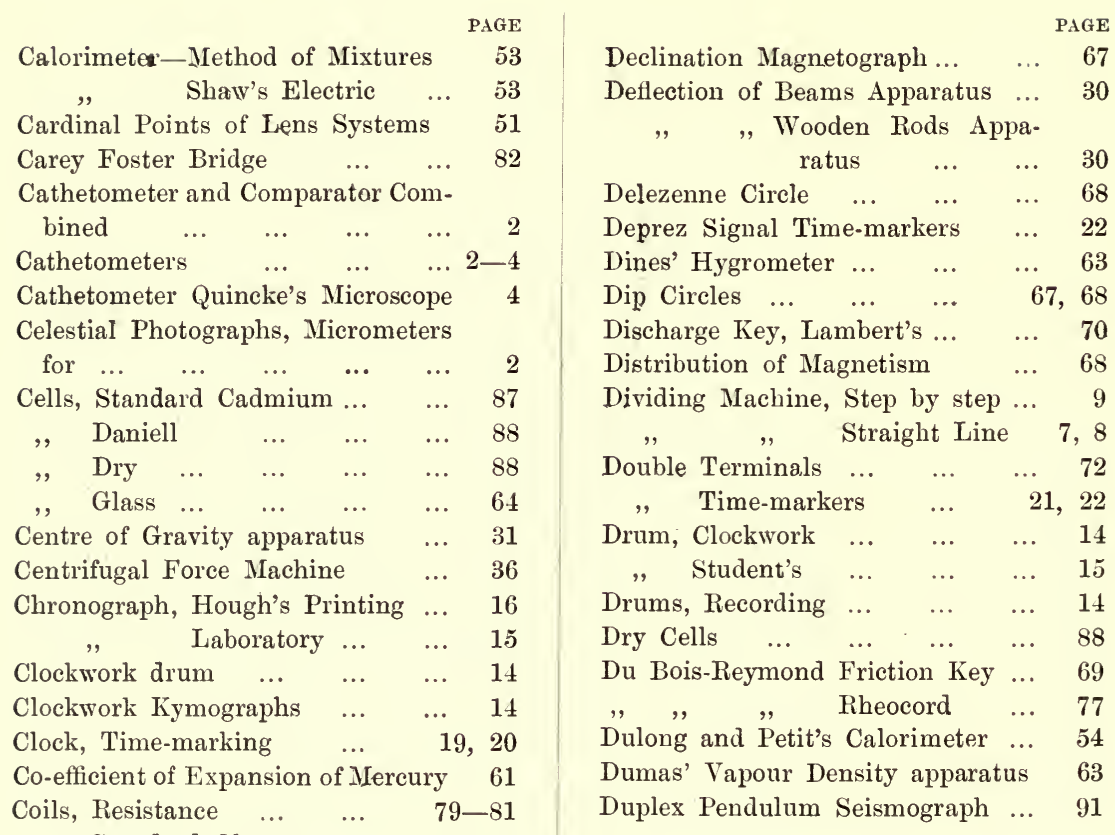

\section{E.}

Elastic Bending of Beams, Ap$\begin{array}{lllll}\text { paratus for } & \ldots & \ldots & \ldots & 29\end{array}$

Comparator and Cathetometer com$\begin{array}{llllll}\text { bined } & \ldots & \ldots & \ldots & \ldots & 2\end{array}$

Composition of Moments Apparatus 35

Compound Ballistic Balance ... 32

$\begin{array}{lllll}\text {, } & \text { Pendulum } & \ldots & \ldots & 35\end{array}$

$\begin{array}{lllll}\text { Concave Mirrors } & \ldots & \ldots & \ldots & 64\end{array}$

$\begin{array}{lllll}\text { Condensing Lens } & \ldots & \ldots & \ldots & 45\end{array}$

$\begin{array}{llll}\text { Conductivity of Gases } \quad \ldots & \ldots & 65\end{array}$

Constant Pressure Apparatus $\quad \ldots \quad 61$

, Temperature Apparatus $\quad 53$

,, Volume Air Thermometer 61

$\begin{array}{lllll}\text { Contact Breaker } & \ldots & \ldots & \ldots & 19\end{array}$

, Key, Single $\quad \ldots \quad \ldots 69$

, Makers, Vibrating _.. 19

$\begin{array}{lllll}\text { Cup Micrometer } & \ldots & \ldots & \ldots & 6\end{array}$

Electrical Apparatus $\quad \ldots \quad 69-88$

, Energy, Heat Equivalent

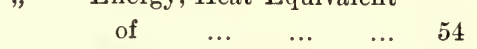

, $\quad$ Notors, Lundell's $\quad \ldots \quad 39$

, $\quad$ Recorder, Callendar's ... 88

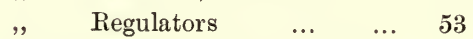

Electrically maintained Tetanus

$\begin{array}{llllll}\text { Springs } & \ldots & \ldots & \ldots & \ldots & 19\end{array}$

Electrolytic Resistance, Cells for 83

Expansion of Gases, Apparatus ... 61

Expansion of Metal Bars ... ... 52

Ewing's Extensometers ... 23-26
$, \quad \quad, \quad$ (Patent Mi-
croscope type) $\ldots \quad \ldots \quad \ldots \quad 24$

, $\quad$ Seismographs $\quad \ldots \quad 97-99$

Extension and Vibration of Springs,

$\begin{array}{lllll}\text { Apparatus for } & \ldots & \ldots & \ldots & 31\end{array}$

$\begin{array}{lllll}\text { Daniell Cells ... } & \ldots & \ldots & \ldots & 88\end{array}$

Daniell's Hygrometer $\quad \ldots \quad \ldots \quad 63$

D'Arsonval Galvanometers $\quad 73,74$

$\begin{array}{lllll}\text { Extension of wires ... } & \ldots & \ldots & 31\end{array}$

Extensometers, Ewing's ... 23-26

Apparatus for ... 25 
PAGE

F.

Fibres, Quartz $\quad \ldots \quad \ldots \quad \ldots 7,75$

Fleuss' Vacuum Pump ... ... 37

$\begin{array}{lllll}\text { Fluid Pressure } \quad \ldots & \ldots & \ldots & 37\end{array}$

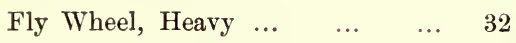

Focal Lines Apparatus $\quad \ldots \quad \ldots \quad \ldots 1$

$\begin{array}{llllll}\text { Force, Centrifugal } & \ldots & \ldots & \ldots & 36\end{array}$

Forces, Parallelogram of $\ldots \quad \ldots \quad 36$

,, Triangle and Polygon of ... 36

$\begin{array}{lllll}\text { Forks, Tuning } \quad \ldots & \ldots & \ldots & 18\end{array}$

Freezing Point of Solutions _.. 65

Friction of Cord on Pulley _.. 35

,, Inclined Plane ... ... 36

, $\quad$ Key, Du Bois-Reymond's $\quad 69$

$\begin{array}{lllll}\text { Funicular Polygon } & \ldots & \ldots & \ldots & 36\end{array}$

\section{G.}

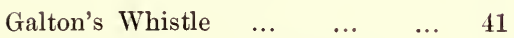

Galvanometer and Bridge Key ... 70

Galvanometers, Ayrton-Mather

D'Arsonval 73, 74

$\begin{array}{cllll},, & \text { Ballistic ... } & \ldots & 75 \\ ,, & \text { Lamps, stands and } & \\ & \text { scales } & \ldots & \ldots & 77 \\ ,, & \text { Shunt } & \ldots & \ldots & 76 \\ ,, & \text { Sine } & \ldots & \ldots & 75 \\ ,, & \text { Student's } & \ldots & \ldots & 75 \\ ,, & \text { Tangent } & \ldots & \ldots & 76 \\ \text {, } & \text { Thomson } & \text { High } & \text { Re- } \\ & \text { sistance... } & \ldots & 74\end{array}$

,

Thomson Low Resistance... ... 75

Gas Engine, Humphrey's Apparatus 37

, Indicator, Scale Temperature $\quad 59$

,, Regulators _.. $\quad \ldots \quad$... 53

" Thermometer, Standard $\quad$... 61

Gases, Conductivity of $\quad \ldots \quad \ldots 65$

,. Expansion of, Apparatus ... 61

Gauges, Micrometer... $\quad \ldots \quad \ldots \quad 5$

Geometric Tripod Stands ... $\quad \ldots \quad 11$

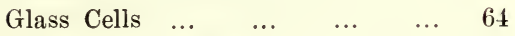

Glass Table, adjustable $\quad \ldots \quad \ldots \quad \ldots \quad 11$

Glazed Paper... $\quad \ldots \quad \ldots \quad 16,17$

Gotch's Simple Stand ... ... 10

Gravity, determination of centre of 31

Griffiths' Self-Testing Bridge $\quad 84-87$

, Thermo-electric Key ... 70

,", ,, ," and Commutator $\ldots \quad \ldots \quad 71$
H.

Handle for holding Drum ... $\quad \ldots \quad 16$

$\begin{array}{lllll}\text { Harmonograph } & \ldots & \ldots & \ldots & 41\end{array}$

Heat, Apparatus ... ... 52-65

,, Equivalent of Electric Energy 54

,, Mechanical Equivalent of ... 55

, Melloni's Apparatus ... $\quad 63,64$

Hicks' Ballistic Balance $\ldots . \quad \ldots \quad 32$

Hope's Apparatus Maximum Density 63

Horizontal Force Magnetograph ... 67

Hough's printing Chronograph ... 16

Humplrey's Gas Engine Apparatus 37

Hürthle's Smoke-Spray $\quad \ldots \quad$... 16

$\begin{array}{llll}\text { Hydrostatic Paradox } & \ldots & \ldots & 37\end{array}$

Hygrometer, Daniell's $\quad \ldots \quad \ldots 63$

,, Dines'... ... $\quad \ldots \quad 63$

,, Mason's Wet and Dry

Bulb... $\quad \ldots \quad \ldots 63$

Hypsometer, Guillaume's $\ldots .61$

$\begin{array}{lllll}, & \text { Regnault's } & \ldots & \ldots & 61\end{array}$

I.

Ice Calorimeter, Lavoisier's $\quad \ldots \quad 53$

$\begin{array}{llllll}\text { Ice Vessel, } & \ldots & \ldots & \ldots & \ldots & 61\end{array}$

$\begin{array}{lllll}\text { Inclined Planes } & \ldots & \ldots & \ldots & 36\end{array}$

Indicator, Temperature $\quad \ldots \quad 57-59$

Inertia, Moments of $\quad \ldots \quad 35-37$.

$\begin{array}{lllll}\text { Inertia Solids } & \ldots & \ldots & \ldots & 37\end{array}$

Insulating Stands, Maxwell's $\quad \ldots \quad 69$

J.

Jena Glass Thermometer's ... $\quad$.. 59

Jolly's Air Thermometer ... $\quad \ldots \quad 61$

,, Balance $\quad \ldots \quad \ldots . \quad \ldots \quad 36$

K.

Kater Compound Pendulum _.. 35

Key, Du Bois-Reymond's, Friction 69

,, Galvanometer and Bridge ... 70

$\begin{array}{lllll}\text {,, Knock-over } & \ldots & \ldots & \ldots & 71\end{array}$

,, Lambert's Discharge ... $\quad \ldots \quad 70$

$\begin{array}{llllll},, & \text { Nereury } & \ldots & \ldots & . . & 69\end{array}$

$\begin{array}{lllllll}, & \text { Morse } & \ldots & \ldots & \ldots & \ldots & 69\end{array}$

$\begin{array}{llllll}\text {,, Plug } & \ldots & \ldots & \ldots & \ldots & 72\end{array}$

$\begin{array}{lllll}\text {, } & \text { Porcelain Plug } \quad \ldots & \ldots & 72\end{array}$

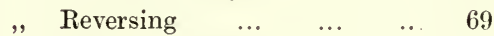

$\begin{array}{lllll}\text {, Short Circuiting } & \ldots & \ldots & 70\end{array}$ 


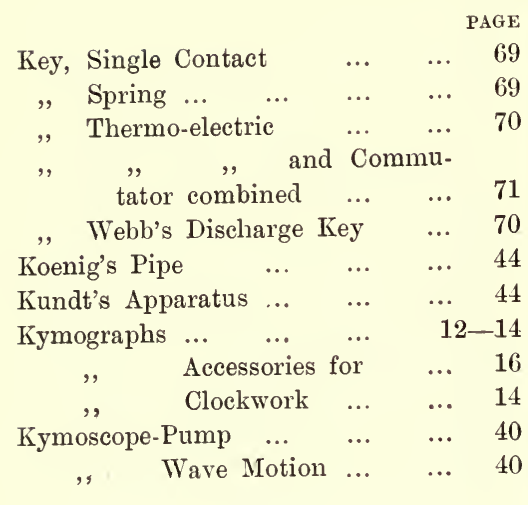

L.

Laboratory Seconds Clock ... _.. 20

$\begin{array}{lllll}\text {,, } & \text { Chronograph } & \ldots & \ldots & 15\end{array}$

Lambert's Discharge Key ... ... 70

Lamps, Galvanometer $\quad \ldots \quad \ldots \quad 77$

Lamp Stand, Transparent scale .. 77

Lantern, Optical $\quad \ldots \quad \ldots \quad \ldots \quad \ldots \quad 45$

Lathe, Bed Apparatus $\quad \ldots \quad 29,30$

Lavoisier's Ice Calorimeter $\quad \ldots \quad 53$

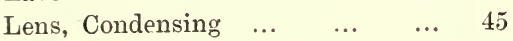

Lenses, Boys' Wheel of $\ldots \quad \ldots \quad 46$

, Cardinal Points of .. 51

, Convex Half Lens _.. 51

Leslie's Cube ... $\quad \ldots \quad \ldots \quad \ldots \quad \ldots \quad 64$

$\begin{array}{lllll}\text { Level Tester, Spirit... } & \ldots & \ldots & 6\end{array}$

Lever, Optical $\quad \ldots \quad \ldots \quad \ldots \quad \ldots \quad 35$

$\begin{array}{llllll}\text { Light } & \ldots & \ldots & \ldots & \ldots & 45-51\end{array}$

Line Dividing Machine, Straight... 7

Lissajou's Curves, Apparatus for... 41

Locatelli's Lamp $\quad \ldots \quad \ldots \quad \ldots \quad \ldots 64$

$\begin{array}{llll}\text { Ludwig's Kymographs } & \ldots & \ldots & 12\end{array}$

Lundell Electric Motors $\quad \ldots \quad \ldots \quad 39$

M.

\begin{tabular}{|c|c|c|}
\hline achines, Divid & & $7-$ \\
\hline Iagnetism $\quad \ldots$ & & $66-68$ \\
\hline tism, Distribution o & & $\ldots$ \\
\hline aphs & & $\cdots$ \\
\hline agnetometer, Student's & $\ldots$ & $\ldots$ \\
\hline Uni & .. & \\
\hline -ended & $\cdots$ & $\ldots$ \\
\hline Bar ... & $\cdots$ & \\
\hline
\end{tabular}

Magnets, Suspended $\quad \ldots \quad \ldots 6 \quad 68$

Marking off Apparatus for Extenso$\begin{array}{llllll}\text { meter } & \ldots & \ldots & \ldots & \ldots & 25\end{array}$

Maximum Density of water $\quad \ldots \quad 63$ Tension of Vapours ... 63

Maxwell's Vibrating Needle $\quad \ldots \quad 28$

Measuring Instruments _.. $\quad$.. 1-9

Mechanical Apparatus $\quad$.. $\quad 23-39$ ,, Equivalent of Heat Ap.

$\begin{array}{llllll}\text { paratus } & \ldots & \ldots & \ldots & \ldots & 55\end{array}$

$\begin{array}{llllll}\text { Megohm } & \ldots & \ldots & \ldots & \ldots & 80\end{array}$

$\begin{array}{lllll}\text { Melde's Apparatus } & \ldots & \ldots & \ldots & 42\end{array}$

Melloni's Apparatus... $\quad \ldots \quad \ldots \quad \ldots 3$ $, \quad, \quad$ Accessories for 64

$\begin{array}{llll}\text { Mercury Commutator } & \ldots & \ldots & 72\end{array}$ ,, , , Rocking .. 71

,, Co-efficient of Expansion 61

$\begin{array}{lllll}\text { Mercury Key ... } & \ldots & \ldots & \ldots & 69\end{array}$ , Thermometer, Apparatus $\begin{array}{lllll}\text { for Calibrating } & \ldots & \ldots & \ldots & 60\end{array}$

$\begin{array}{llllll}\text { Metre Bridge ... } & \ldots & \ldots & \ldots & 82\end{array}$ $\begin{array}{llll}\text {, Scale of Nickel Steel } & \ldots & 7\end{array}$

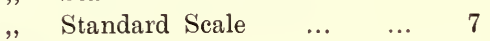

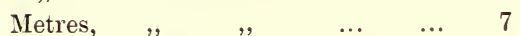
Meyer's Vapour Density Apparatus 63

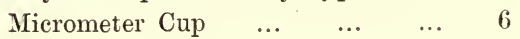

$$
\begin{array}{lllll}
,, & \text { Gauges } \ldots & \ldots & \ldots & 5 \\
,, & \text { Telescope } & \ldots & \ldots & 4
\end{array}
$$

Micrometers for measuring Celestial

$\begin{array}{lllll}\text { Photographs } & \ldots & . . & \ldots & 2\end{array}$

Microscope Cathetometer, Quincke's 4

Microscopes, Reading _... ... 1

Microscope, Travelling, Screw $\quad \ldots \quad 2$ for Dividing Machine 7

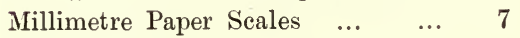
Rotating, on stand ... 44

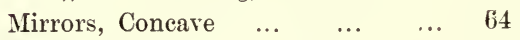

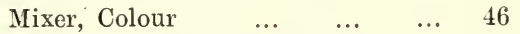

Modulus of Rigidity of Wires $\quad \ldots \quad 28$ ,, of Torsion in Rods _.. 29 , Young's, Apparatus for ... 28

Moments, Composition of ... ... 35 , of Inertia $\quad \ldots \quad 3 \tilde{s}-37$ , , , $\quad$ of rods $\quad \ldots \quad 35$

$\begin{array}{llllll}\text { Monochord } & \ldots & \ldots & \ldots & \ldots & 41\end{array}$

$\begin{array}{lllll}\text { Morin's Machine } & \ldots & \ldots & \ldots & 34\end{array}$

$\begin{array}{llllll}\text { Morse Key } & \ldots & \ldots & \ldots & \ldots & 69\end{array}$

Motors, Lundell Electric $\quad \ldots \quad \ldots \quad \ldots \quad 39$

„, "Thirlmere" Water ... 38 
PAGE

N.

Nickel-Steel, Standard Scales $\quad \ldots \quad 7$

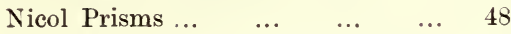

O.

Ohms subdivided

Ohm Standard Coils $\quad \ldots \quad r \quad 78-79$

One Megohm (divided) $\quad \ldots \quad \ldots \quad 80$

$\begin{array}{llll}\text { One Ohm subdivided } & \ldots & \ldots & 80\end{array}$

$\begin{array}{lllllll}\text { Opisometer } & \ldots & \ldots & \ldots & \ldots & 6\end{array}$

Optical Bench $\quad \ldots \quad \ldots \quad 46-48$

, Lantern $\quad \ldots \quad \ldots . \quad \ldots \quad 45$

$\begin{array}{llllll} & \text { Lever... } & \ldots & \ldots & \ldots & 35\end{array}$

P.

Page's Gas Regulator $\quad \ldots \quad \ldots \quad 53$

$\begin{array}{llll}\text { Paper Nillimetre Scales } & \ldots & \ldots & 7\end{array}$

Parallel Beam Nozzle $\quad \ldots \quad \ldots \quad \ldots 45$

$\begin{array}{llll}\text { Parallelogram of Forces } & \ldots & \ldots & 36\end{array}$

Pendulum, Ballistic... $\quad \ldots \quad \ldots \quad \ldots \quad 32$

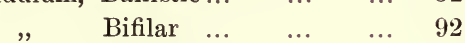

$\begin{array}{lllll} & \text { Compound } & \ldots & \ldots & 35\end{array}$

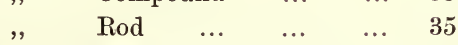

$\begin{array}{lllll}\text { Phoneidoscope } & \ldots & \ldots & \ldots & 41\end{array}$

Photographic Apparatus for Bifilar

$\begin{array}{llllll}\text { Pendulum } & \ldots & \ldots & \ldots & \ldots & 92\end{array}$

Photographic Apparatus for Tromo-

$\begin{array}{llllll}\text { meter } & \ldots & \ldots & \ldots & \ldots & 91\end{array}$

Photometer, Bunsen's $\quad$... $\quad$.. 45

$\begin{array}{lllll}\text { Pipe, Koenig's } & \ldots & \ldots & \ldots & 44\end{array}$

Planes, Inclined $\quad \ldots . \quad \ldots \quad \ldots \quad$.. 36

Planimeter, Amsler's $\quad \ldots \quad \ldots r 6$

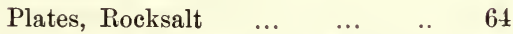

Platinum Spiral and Holder $\quad \ldots \quad 64$

Platinum Thermometers, Callendar and Griffiths' $\quad \ldots \quad \ldots \quad \ldots \quad \ldots 5$

$\begin{array}{llll}\text { Plug Hole Cleaners ... } & \ldots & \ldots & 87\end{array}$

$\begin{array}{llllll}\text { Plug Keys } & \ldots & \ldots & \ldots & \ldots & 72\end{array}$

$\begin{array}{llll}\text { Plug Switches, Battery } & \ldots & \ldots & 72\end{array}$

$\begin{array}{lllll}\text { Pneumatic Table } & \ldots & \ldots & \ldots & 11\end{array}$

$\begin{array}{lllll}\text { Pocket Callipers } & \ldots & \ldots & \ldots & 7\end{array}$

Poggendorff's Bridge $\quad \ldots \quad \ldots .82$

Pohl's Rocking Mercury Commutator 71

Polariscope, stand for $\quad \ldots . \quad \ldots \quad 48$

Polygon, Funicular ... $\quad \ldots \quad \ldots \quad 36$

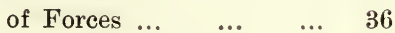

$\begin{array}{llll}\text { Porcelain Plug Keys } & \ldots & \ldots & 72\end{array}$

$\begin{array}{lllll}\text { Post-Office Bridge } & \ldots & \ldots & \ldots & 82\end{array}$

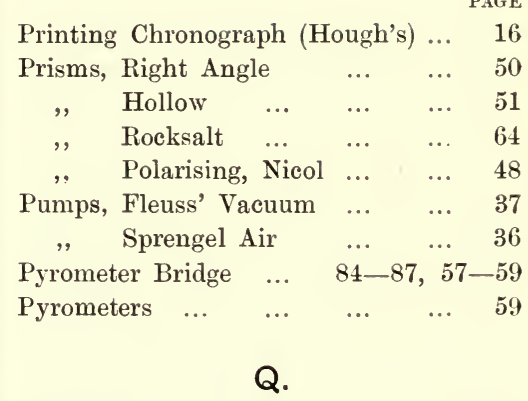

Quartz Fibres $\quad \ldots \quad \ldots \quad 67,75$

Quincke's Adjustable Glass Table 10

, Microscope Cathetometer 4

R.

$\begin{array}{llll}\text { Radio-Micrometer, Boys' } & \ldots & \ldots & 64\end{array}$

$\begin{array}{llllll}\text { Ratio Boxes } & \ldots & \ldots & \ldots & \ldots & 80\end{array}$

$\begin{array}{llll}\text { Reading Microscope ... } & \ldots & \ldots & 1\end{array}$

$\begin{array}{lllll}, & \text { Telescopes ... } & \ldots & \ldots & 4\end{array}$

Recording Apparatus $\quad \ldots \quad 12-16$

$\begin{array}{llllll}, & \text { Pen } & \ldots & \ldots & \ldots & 17\end{array}$

Recorders, Callendar's Electric ... 88

Reflection, Apparatus for demon$\begin{array}{lllll}\text { strating Laws of ... } & \ldots & \ldots & 46\end{array}$

Refraction, Apparatus for demonstrating Laws of ... $\quad \ldots \quad \ldots \quad \ldots \quad 46$

Regulators, Bi-metallic Electric $\ldots \quad 53$

$\begin{array}{llllll}, & \text { Gas } & \ldots & \ldots & \ldots & 53\end{array}$

Regnault's Hypsometer $\quad \ldots \quad \ldots \quad 61$

,, VapourTension Apparatus 63

Reichert's Gas Regulator ... ... 53

Resistance Boxes $\quad \ldots \quad 78,80,82,83$

$\begin{array}{lllll}, & \text { Electrolytic } & \ldots & \ldots & 83\end{array}$

" $\quad$ Coils, Single $\quad . . \quad$... 79

$\begin{array}{lllll}\text {, } & \text { Coils, Set of } & \ldots & \ldots & 81\end{array}$

, Shunts, Low $\quad . . \quad$... 80

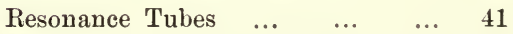

Resonator and Tuning Fork $\quad \ldots \quad 44$

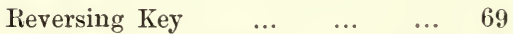

Rheocord, Du Bois-Reymond ... 77

$\begin{array}{llllll}\text { Rheostat } & \ldots & \ldots & \ldots & \ldots & 77\end{array}$

$\begin{array}{lllll}\text {, Wheatstone's } & \ldots & \ldots & 77\end{array}$

Right-angle Prisms ... $\quad \ldots \quad \ldots \quad \ldots 0$

Rocking Mercury Commutator ... 71

$\begin{array}{lllll}\text { Rocksalt Lens } & \text {... } & \text {... } & \text {.. } & 64\end{array}$

$\begin{array}{llllll}\text {,, } & \text { Prisms } & \ldots & \ldots & \ldots & 64\end{array}$

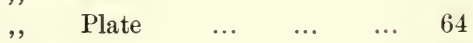

$\begin{array}{lllll}\text { Rod Pendulum } & \ldots & \ldots & \ldots & 35\end{array}$ 


\begin{tabular}{llll} 
& \multicolumn{2}{c}{ PAGE } \\
Rolling-Ball Apparatus $\ldots$ & $\ldots$ & 33 \\
Rosenhain's Coal Calorimeter & $\ldots$ & 54 \\
Rotating Mirror on stand ... & $\ldots$ & 44
\end{tabular}

S.

Scales, Standard $\quad \ldots \quad \ldots \quad \ldots 4,6$

$\begin{array}{lllll}\text {, } & \text { Galvanometer } & \ldots & \ldots & 77\end{array}$

$\begin{array}{lllll}\text {,. } & \text { Millimetre Paper } & \ldots & \ldots & 7\end{array}$

$\begin{array}{llllll}\text { Screens } & \ldots & \ldots & \ldots & \ldots & 61\end{array}$

Screw travelling Microseope $\quad \ldots \quad 2$

Searle's Modulus of Rigidity Ap$\begin{array}{llllll}\text { paratus } & \ldots & \ldots & \ldots & \ldots & 28\end{array}$

Searle's Young's Modulus Apparatus $\quad 27$

Sedley Taylor's Phoneidoscope $\quad . . \quad 41$

Seismographs, Ewing's $\quad$.. $\quad 89-91$

Self-Testing Bridges $\quad$.. $\quad 84-87$

Shaw's Electric Calorimeter $\quad \ldots \quad 53$

$\begin{array}{lllll}\text { Shellac varnish } & \ldots & \ldots & \ldots & 16\end{array}$

$\begin{array}{llll}\text { Short Circuiting Key } \quad \ldots & \ldots & 70\end{array}$

$\begin{array}{llll}\text { Shunt, Galvanometer } & \text {.. } & \ldots & 76\end{array}$

Shunts, Low Resistance ... $\quad \ldots \quad 80$

$\begin{array}{lllll}\text { Silver Voltameter } & \ldots & \ldots & \ldots & 9 \check{0}\end{array}$

$\begin{array}{lllll}\text { Simple Stands } \quad \ldots & \ldots & \ldots & 10\end{array}$

Simple Tetanus Spring $\quad \ldots \quad \ldots \quad \ldots 18$

$\begin{array}{lllll}\text { Sine Galvanometer } & . . & \ldots & \ldots & 75\end{array}$

Single Contact Key ... $\quad \ldots \quad \ldots \quad 69$

Single Lever Testing Machine (Ex-

$\begin{array}{llllll}\text { tensometer) } & \ldots & \ldots & \ldots & 26\end{array}$

Single Resistance Coils $\quad \ldots \quad \ldots \quad \ldots 79$

Smoke-Spray, Hürthle's $\quad \ldots \quad \ldots \quad 16$

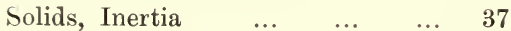

Sound Apparatus $\quad \ldots \quad$... $\quad 40-44$

Specific Gravity Balance ... $\quad \ldots \quad 36$

Spectrometer, Laboratory ... $\quad \ldots \quad 50$

Spectrometers and Spectroscopes (Combined) $\quad \ldots \quad 49$

$\begin{array}{lllll}\text { Spectrophotometer } & \ldots & \ldots & \ldots & 48\end{array}$

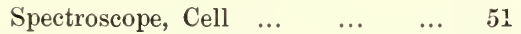

$\begin{array}{lllll}, & \text { Charts } & \ldots & \ldots & 50\end{array}$

$\begin{array}{lllll}\text { Spectroscopes } & \ldots & \ldots & \ldots & 49\end{array}$ ,$\quad$ and Spectrometers (Combined) $\quad \ldots \quad 49$

$\begin{array}{lllll}\text { Spherometers } & \ldots & \ldots & \ldots & 5\end{array}$

$\begin{array}{lllll}\text { Spiral Springs } & \ldots & \ldots & \ldots & 31\end{array}$

$\begin{array}{lllll}\text { Spirit Level Tester ... } & \ldots & \ldots & 6\end{array}$

Sprengel Air Pump ... $\quad \ldots \quad \ldots \quad \ldots 36$

$\begin{array}{llllll}\text { Spring Key } & \ldots & \ldots & \ldots & \ldots & 69\end{array}$

Springs, Extension and vibration of 31
Springs, Spiral, Apparatus for $\quad \ldots \quad 31$

$\begin{array}{llllll}\text {, } & \text { Tetanus } & . . & \ldots & \ldots & \end{array}$

Stand for holding Drums ... $\quad . . \quad 16$

$\begin{array}{llll}\text { Standard Cadmium Cells ... } & \ldots & 87\end{array}$

$\begin{array}{lllll},, & \text { Metre Scale } & \ldots & \ldots & 7\end{array}$

$\begin{array}{llllll}\text {, } & \text { Metres } & \ldots & \ldots & \ldots & 7\end{array}$

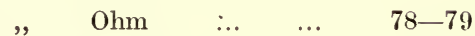

,$\quad$ Scales $\quad \ldots \quad \ldots \quad \ldots 4,6$

Stands, Geometric Tripod ... $\quad \ldots \quad 11$

, Maxwell's Insulating $\quad \ldots \quad 69$

$\begin{array}{lllll}\text { " } & \text { Polariscope ... } & \ldots & \ldots & 48\end{array}$

, for Tuning Forks ... 17-18

Step by Step Dividing Nachine ... 9

Straight Line Dividing Machine ... 7

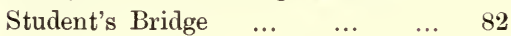

$\begin{array}{llllll}\text {, } & \text { Drum } & \ldots & \ldots & \ldots & 15\end{array}$

$\begin{array}{lllll}, & \text { Magnetometer } & \ldots & \ldots & 66\end{array}$

Supports for Apparatus ... $\quad 10,11$

$\begin{array}{llll}\text { Suspended Magnets } & \ldots & \ldots & 68\end{array}$

$\begin{array}{llll}\text { Switches, Battery Plug } & \ldots & \ldots & 72\end{array}$

$\begin{array}{llllll}\text { Syrens } & \ldots & \ldots & \ldots & \ldots & 44\end{array}$

T.

Table, Adjustable Glass $\quad \ldots \quad \ldots \quad \ldots 11$

$\begin{array}{lllll}\text {,, Cathetometers } & \text {... } & \ldots & 4\end{array}$

$\begin{array}{lllll}\text {, } & \text { for Spirit lamp } \quad \ldots & \ldots & 64\end{array}$

$\begin{array}{llllll}\text {,, Pneumatic } & \ldots & \ldots & \ldots & 11\end{array}$

$\begin{array}{llll}\text { Tangent Galvanometers } & \ldots & \ldots & 76\end{array}$

$\begin{array}{llll}\text { Telescope Nicrometer } & \ldots & \ldots & 4\end{array}$

$\begin{array}{llllll}\text {, } & \text { Reading } \ldots & \ldots & \ldots & 4\end{array}$

Temperature Apparatus, Constant 53

, Indicator, Callendar and Griffiths' 57, 58, 59

Terminals, Double $\ldots \quad \ldots \quad \ldots \quad 72$

Testing Machine, Single Lever ... 26

Tetanus Springs, Electrically main-

$\begin{array}{llllll}\text { tained } & \ldots & \ldots & \ldots & \ldots & 19\end{array}$

Tetanus Springs, Simple $\ldots \quad \ldots \quad \ldots \quad 18$

$\begin{array}{llllll}\text { Thermo-couples } & \ldots & \ldots & \ldots & 59\end{array}$

$\begin{array}{llll}\text { Thermo-electric Keys } \quad \ldots & \ldots & 70\end{array}$

, , , $\quad$ Pyrometers ... 59

$\begin{array}{llllll}\text { Thermo-Pile } & . . & \ldots & \ldots & \ldots & 60\end{array}$

Thermometer, Constant Volume Air 61 Jolly's Air ... ... 61

Standard Gas $\quad \ldots \quad 61$

Thermometers, Callendar's Platinum $\quad 55$ Jena Glass ... ... 59

", Laboratory ... $\quad 56,57$

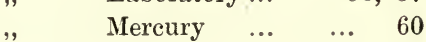


Thermometers, Mercury, Calibration

$\begin{array}{lllllll}\text { of } & \ldots & \ldots & \ldots & \ldots & \ldots & 60\end{array}$

"Thirlmere" Water Motors _.. 38

Thomson High Resistance Galva$\begin{array}{llllll}\text { nometers } & . . & \ldots & \ldots & \ldots & 74\end{array}$

Thomson Low Resistance Galva$\begin{array}{llllll}\text { nometers } & . . & \ldots & \ldots & \ldots & 75\end{array}$

Three Dial Resistance Box $\quad \ldots \quad 83$

Tilting Mirror Apparatus ... $\quad \ldots \quad 26$

Time-marking Instruments $\quad 19-22$

,, ,, Clocks _.. $\quad 19,20$

,, Markers, Deprez Signal ... 22

,, , , , , Double 22

, , , Double for smoked

$\begin{array}{lllll}\text { paper } & \ldots & \ldots & 20\end{array}$

, , Smoked Paper $\quad \ldots \quad 20$

, , , to write with ink, on continuous paper

Torricellian Experiments, Apparatus

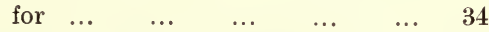

Torsion in Rods, Apparatus for ... $\quad 29$

,, of Wires, ,, , , .. $\quad 29$

$\begin{array}{lllll}\text { Transparent Scales ... } & \ldots & \ldots & 77\end{array}$

Travelling Microscope $\quad \ldots \quad \ldots \quad$... 2

Trifilar Suspension Apparatus ... 35

Tripod Stands, Geometric... $\quad \ldots \quad 11$

$\begin{array}{llllll}\text { Tromometer } & \ldots & \ldots & \ldots & \ldots & 91\end{array}$

$\begin{array}{lllll}\text { Tuning Forks } & \ldots & \ldots & \ldots & 18\end{array}$

,, , Lissajou's Curves ... 41

, , $\quad$ and Resonator ... 44

, , $\quad$ Stands $\quad . . \quad 17-18$

, , $\quad$ Stand, Adjustable ... 42

\section{U.}

Unglazed paper for Kymographs ...

Uniform Acceleration, Rolling-ball

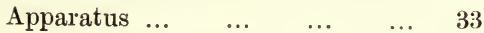

$\begin{array}{llll}\text { Unifilar Magnetometer } & \ldots & \ldots & 66\end{array}$

Universal Shunt, Galvanometer ... $\quad 76$

\section{V.}

PAGE

Vacuum Pump, Fleuss's ... ... 37

Vapours, Densities of, Dunas' Ap$\begin{array}{llllll}\text { paratus } & \ldots & \ldots & \ldots & \ldots & 63\end{array}$

Vapours, Densities of, Victor Meyer's

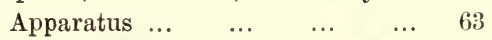

Vapours, Maximum Tension of ... 63

$\begin{array}{lllll}\text { Varnish, Shellac } & \ldots & \ldots & \ldots & 16\end{array}$

Vertical Force Magnetograph $\quad \ldots \quad 67$

$\begin{array}{llllll}\text { Vessel, Ice } & \ldots & \ldots & \ldots & \ldots & 61\end{array}$

Vibrating Contact Makers ... $\quad$.. 19 , Needle, Maxwell's _.. 28

Vibration of Springs, Apparatus for 31

$\begin{array}{lllll}\text { Virtual Images } & \ldots & \ldots & \ldots & 51\end{array}$

\section{W.}

Water Motors, "Thirlmere", ... 38

Wave Motion Kymoseope ... ... 40

Webb's Discharge Key $\quad \ldots \quad \ldots .70$

Wet and Dry Bulb Hygrometer,

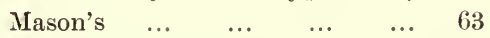

Wheel of Lenses, Boys' $\ldots \quad$... 46

Wheatstone's Bridge $\quad . . \quad 82,85$

$$
\begin{array}{llll}
\text { Rheostat } \quad . . & \ldots & 77
\end{array}
$$

Whipple's Gas Scale Temperature $\begin{array}{llllll}\text { Indicator } & \ldots & \ldots & \ldots & \ldots & 59\end{array}$

Whistle, Galton's $\quad \ldots \quad \ldots \quad \ldots \quad \ldots \quad 41$

Wires, Extension of $\quad$.. $\quad$.. 31

$\begin{array}{lllll}\text {,, } & \text { Torsion of } \ldots & \ldots & \ldots & 29\end{array}$

Wooden Rods, Deflection of $\quad \ldots \quad 30$

\section{Y.}

Young's Modulus, Ewing's $\quad \ldots \quad 26$

Young's Modulus for Wires, Apparatus for determining... $\quad$... $\quad 28$

Young's Modulus, Searle's Apparatus 27 ,, , $\quad$ of Rigidity of wires, Searle's Apparatus for determining $\ldots \quad \ldots \quad \ldots \quad \ldots \quad 28$ 





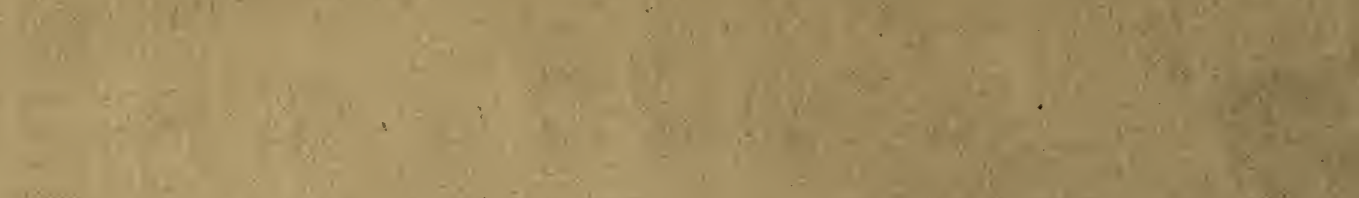
30

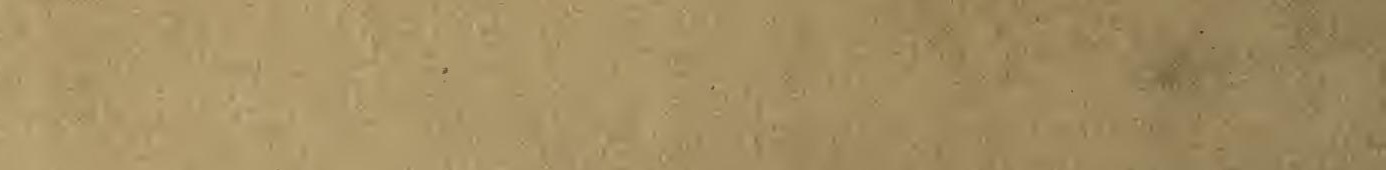

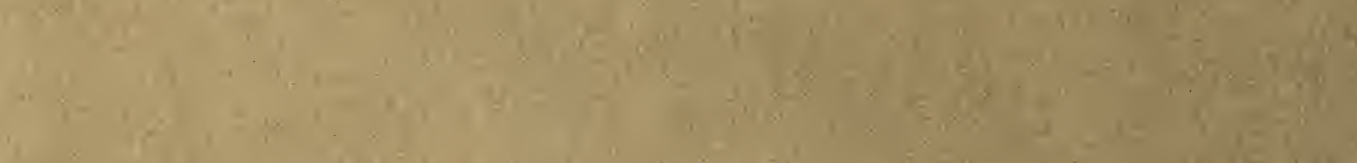

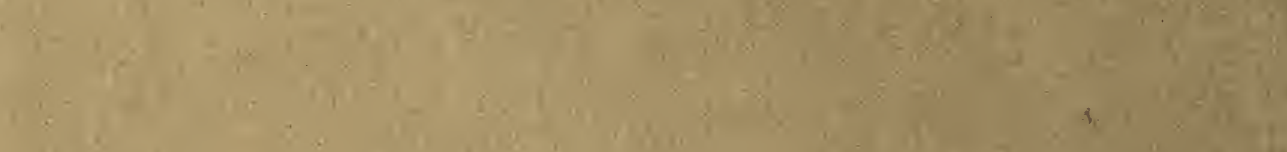

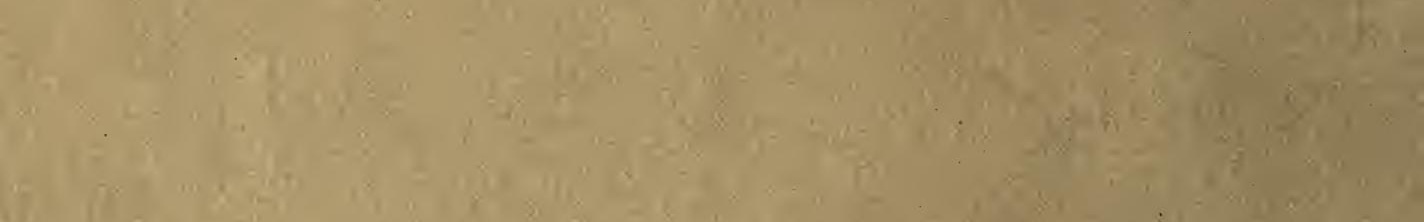

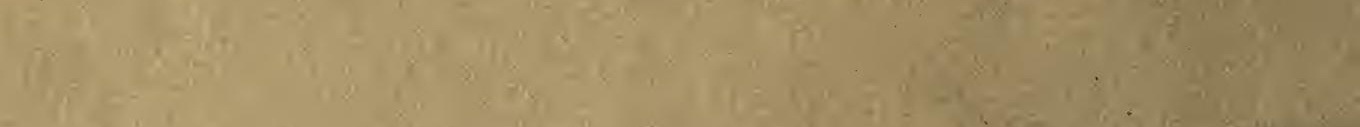

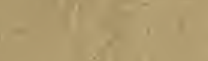

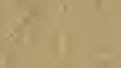

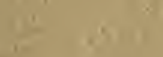

$(3)$ $\operatorname{los}^{2}$

(n)

$\left(x+2 x^{3}=0\right.$

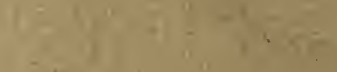

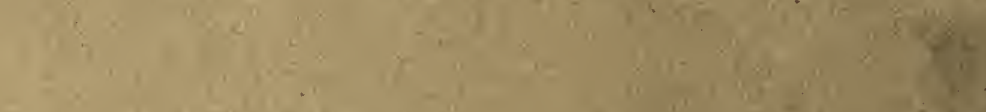

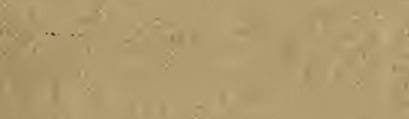

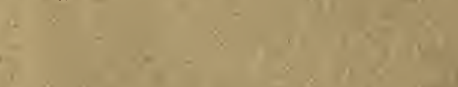
i. $15 \times$

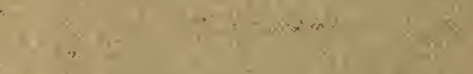

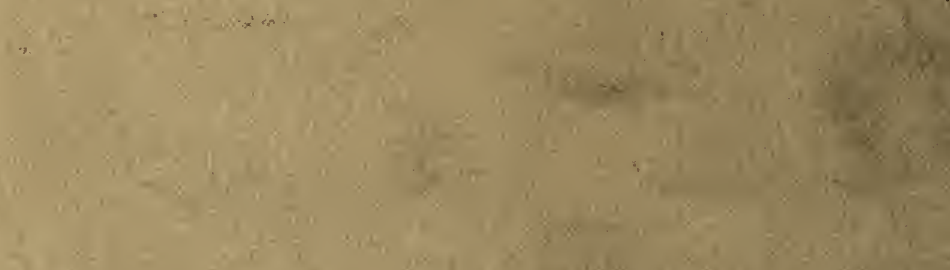

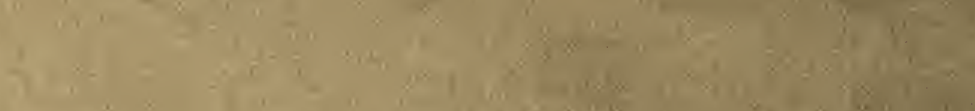

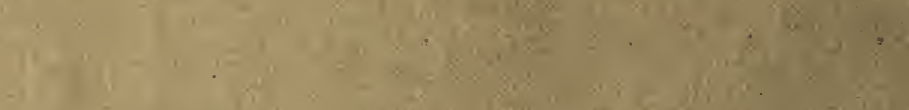

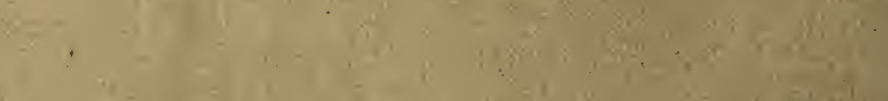

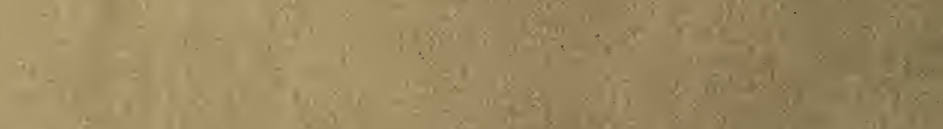
axis.

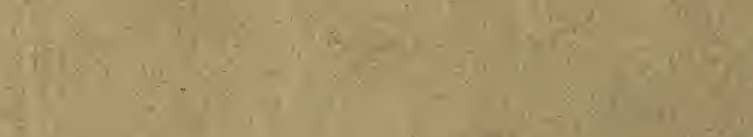

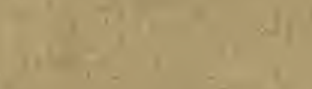

in

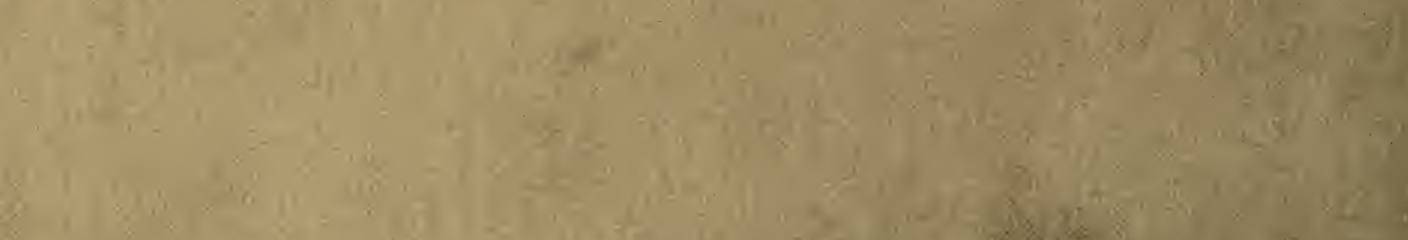

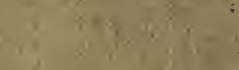
D.

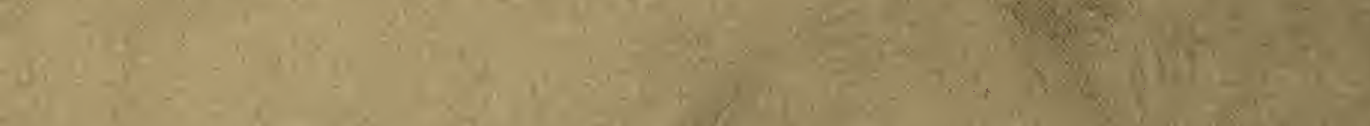

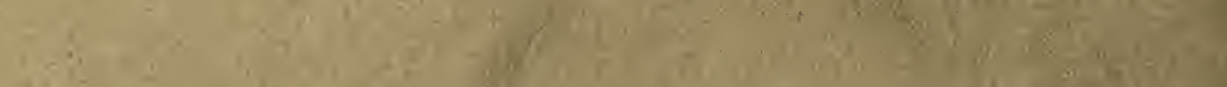
2.

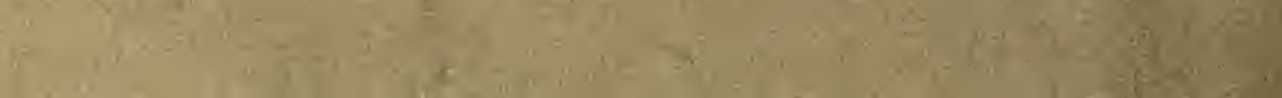

